University of South Florida

DIGITAL COMMONS

Digital Commons @ University of

@ UNIVERSITY OF SOUTH FLORIDA

South Florida

September 2015

\title{
Does the Format of Internal Control Disclosures Matter? An Experimental Investigation of Nonprofessional Investor Behavior
}

Amanuel Fekade Tadesse

University of South Florida, amanuel1@usf.edu

Follow this and additional works at: https://digitalcommons.usf.edu/etd

Part of the Accounting Commons

\section{Scholar Commons Citation}

Tadesse, Amanuel Fekade, "Does the Format of Internal Control Disclosures Matter? An Experimental Investigation of Nonprofessional Investor Behavior" (2015). USF Tampa Graduate Theses and Dissertations.

https://digitalcommons.usf.edu/etd/5780

This Dissertation is brought to you for free and open access by the USF Graduate Theses and Dissertations at Digital Commons @ University of South Florida. It has been accepted for inclusion in USF Tampa Graduate Theses and Dissertations by an authorized administrator of Digital Commons @ University of South Florida. For more information, please contact digitalcommons@usf.edu. 
Does the Format of Internal Control Disclosures Matter?

An Experimental Investigation of Nonprofessional Investor Behavior

by

Amanuel Fekade Tadesse

A dissertation submitted in partial fulfillment of the requirements for the degree of

Doctor of Philosophy in Business Administration with a concentration in Accounting

Lynn Pippenger School of Accountancy

Muma College of Business

University of South Florida

Co-Major Professor: Uday Murthy, Ph.D.

Co-Major Professor: Dahlia Robinson, Ph.D.

Jacqueline Reck, Ph.D.

Getachew Dagne, Ph.D.

Date of Approval:

July 7, 2015

Keywords: Internal Control Weaknesses, Material Weakness, Control Deficiency, Presentation Format, Disaggregation, SOX 404, Sarbanes Oxley

Copyright (C) 2015, Amanuel Fekade Tadesse 


\section{DEDICATION}

I would like to dedicate my dissertation to my brother, Fikre-selassie Tadesse, and my sister, Selamawit Fekade. My brother inspired me to pursue my doctoral studies and has provided me with continued guidance throughout my life. My sister has also been an inspiration as she made research and writing seem easy and encouraged me along the way.

I would also like to dedicate this dissertation to my parents, Fekade-selassie Tadesse and Menbere Seifu. They have made many sacrifices throughout their lives to ensure that their children got proper education. I wish to thank them for the sacrifices they have made and hope that they consider this dissertation as a sign of their success.

I would also like to thank my significant other, Genet Aramde, who was always there for me throughout the program. Thank you for your encouragement, continued love, and support. Genet, you are Godsend and I am very lucky to have you. 


\section{ACKNOWLEDGMENTS}

I would like to thank God for making everything possible throughout my life. I am truly grateful that you have answered my prayers. I would also like to thank my family for supporting me throughout my doctoral studies. The amount of encouragement, love, and support I have received from my family throughout my doctoral studies is unimaginable. I cannot thank you all enough.

I would also like to thank my dissertation co-chairs, Dr. Uday Murthy and Dr. Dahlia Robinson. Thank you for being patient with me and giving me guidance on every step along the way. You spent many hours helping me address issues, reviewing my instrument and going back and forth through multiple iterations. It is an honor to have received both your support and I am truly thankful. Dr. Murthy, thank you for teaching me how to do behavioral research. I appreciate the attention you give to doctoral students and how you are always available to help us. Thank you for spending countless hours meeting with me and providing the much needed support and mentorship. Dr. Robinson, thank you for providing career guidance and the needed continuous push to help me finish in a timely manner.

I would also like to thank my dissertation committee members, Dr. Jaqueline Reck and Dr. Getachew Dagne. Dr. Reck, I thank you for being very kind and encouraging. Thank you for meeting with me countless times throughout the program and being a good advisor and counselor. I always came to your office feeling down and left your office feeling positive and optimistic. Dr. Dagne, thank you for providing support with statistical methods in this 
dissertation. Dr. Dagne has been very supportive and helpful in questions that are sometimes beyond the scope of the dissertation. I also thank you for your general advice beyond statistics.

I would also like to thank my friend and mentor Dr. Mark Mellon for the support and advice in the dissertation. Thank you for your guidance and feedback on multiple versions of the paper. I also thank you for the encouragement and general advice. I would like to thank Daphne Simmonds, Don Wenger, Peter Kipp, Kevin Agnew, Dr. Neal Snow, Dr. Rina Limor, Dr. Tom Smith, Dr. Jim Withworth and Dr. Chris Andrews for providing various feedback in formulating my idea, revising my experimental instrument, and participating in my workshop presentations. Thank you for your time and support. I would especially like to thank Don Wengler for taking notes during my presentations, for providing feedback on multiple versions of the paper and instrument, and for being a true friend.

I would also like to thank Dr. Patrick Wheeler for providing support and feedback on my dissertation. Thank you for your support throughout my career search and for providing me with helpful comments.

I would also like to thank my advisors and mentors: Dr. Harv Busta, Dr. Joel Strong, and Dr. Bill Brown. Thank you for being an inspiration throughout my MBA program at the St. Cloud State University and encouraging me to pursue my doctoral studies. I also want to thank my friends Vi Dinndorf and Don Dinndorf for the support and kindness.

Last but not least, I would like to thank my friends Dr. Anas Tom, Ashimi Traore, Richard McNamara, and Ranajit Mahrok who encouraged me to keep going when I came across obstacles. I would also like to thank my friends Bezawit Girma, Kirubel Abera, Brihane Temeliso, Anteneh, Dr. Seneshaw Tsegaye, and Rahel Getahun. 


\section{TABLE OF CONTENTS}

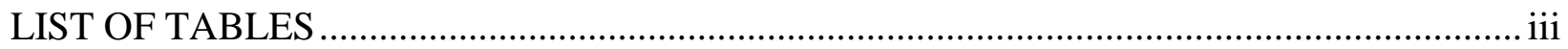

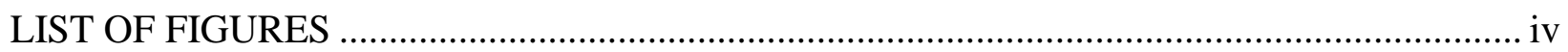

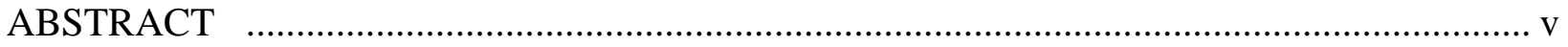

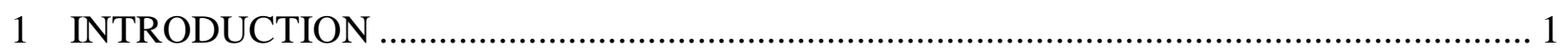

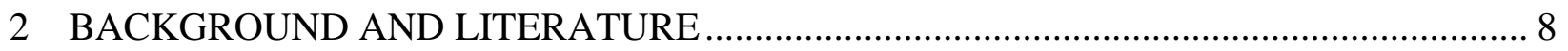

2.1 The Sarbanes-Oxley Act and Internal Control Reporting........................................... 8

2.1.1 Consequences of Internal Control Weakness Disclosures ...............................8

2.1.2 Is the Permanent Exemption of Non-accelerated Filers from Section 404(b) Warranted?...................................................................................10

2.1.2.1 Certification of management's Internal Control reporting........... 11

2.1.2.2 Classification of deficiencies in Internal Control by severity: Material Weaknesses and Control Deficiencies ........................... 12

2.2 Incremental Information vs. Management Obfuscation ............................................ 13

2.2.1 Documented Lack of Internal Control Reporting Transparency ..................14

2.3 The structure of the Internal Control Report............................................................... 15

2.4 Presentation Attributes of Disclosures................................................................... 16

2.4.1 Disaggregation.........................................................................................16

2.4.2 Readability............................................................................................16

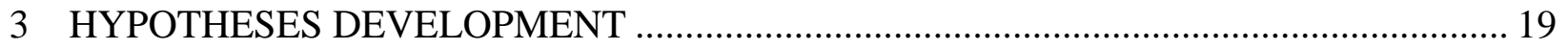

3.1 Presentation Salience of ICW Information in IC Reports .................................... 21

3.1.1 Accessibility of ICW Information in IC Reports ...................................21

3.1.2 Processing Fluency of ICW Information in IC Reports ...............................22

3.2 Disaggregation of ICW Information in IC Reports (Unpacking) ............................. 24

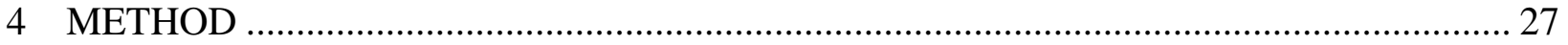

4.1 Experimental Design........................................................................................... 27

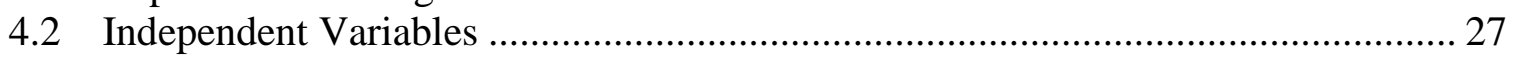

4.3 Dependent Variables ........................................................................................... 28

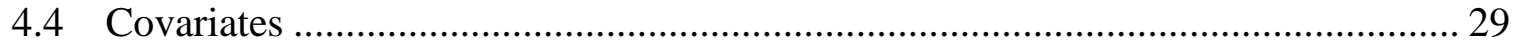

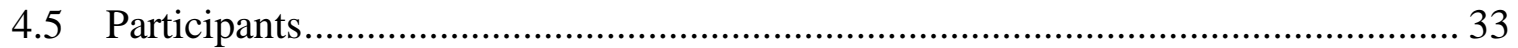

4.6 Tasks and Procedures............................................................................................. 33

$4.7 \quad$ Statistical Analyses .................................................................................................. 35

4.7.1 Manipulation Checks..............................................................................35

4.7.2 Hypotheses Testing …………………………..........................................36

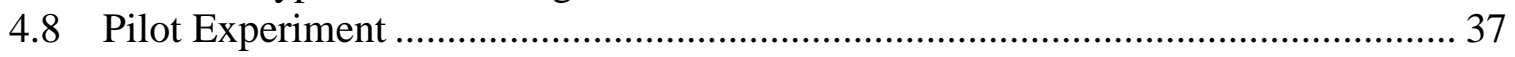




\section{RESULTS 41}

5.1 Manipulation Checks, Attention Checks, and Final Sample Size ......................... 41

5.1.1 Attention Checks ..................................................................................41

5.1.2 Manipulation Checks and Final Sample Size..........................................41

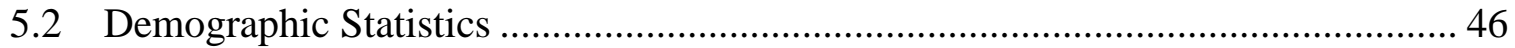

5.3 Descriptive Statistics of Dependent Variables and other Related Variables ........... 48

5.4 Correlations among Dependent Variables and other Related Variables.................. 49

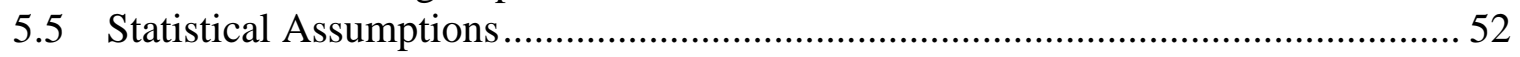

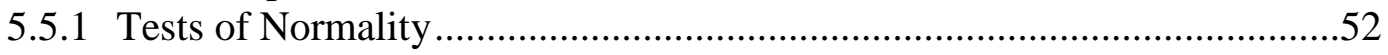

5.5.2 Tests of Homogeneity of Variance-Covariance Matrices and

Equality of Error Variances................................................................54

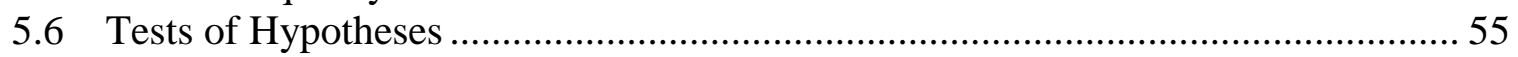

5.6.1 Risk of Misstatement (Tests of Hypotheses 1 and 3) ................................58

5.6.2 Investing Judgments (Tests of Hypotheses 2 and 4) ..............................62

5.6.2.1 Impression of investment ................................................... 63

5.6.2.2 Likelihood of stock price decrease / increase.......................... 66

5.6.2.3 Investment amount .......................................................... 69

5.6.2.4 Summary of hypotheses tests on investing judgments ............... 72

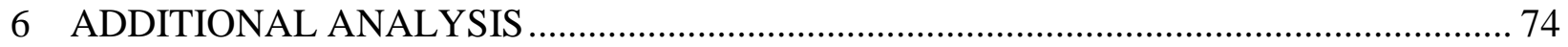

6.1 The Effect of Nonprofessional Investor Sophistication (Experience, Confidence, and Financial Literacy) ......................................................... 74

6.2 Management Trust, Competence, and Credibility .............................................. 84

6.3 The Effect of Salience on Information Acquisition in IC Reports .......................... 86

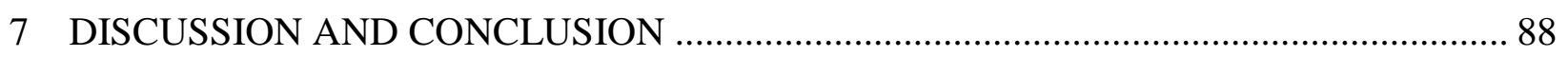

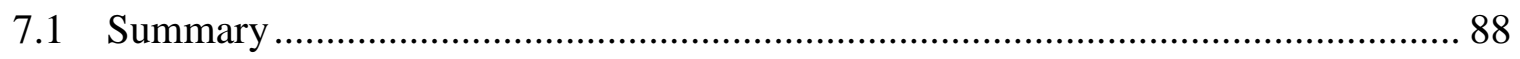

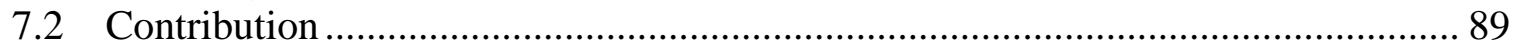

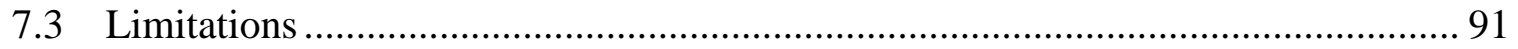

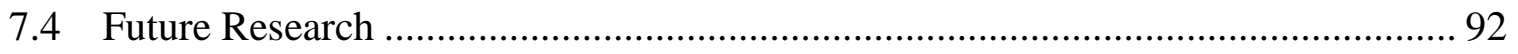

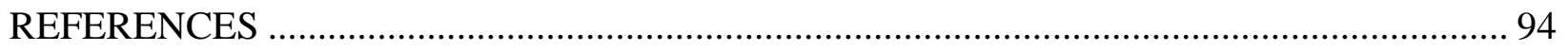

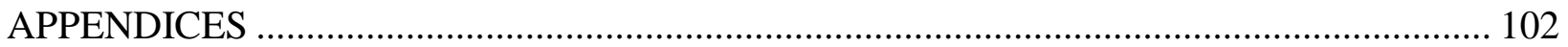

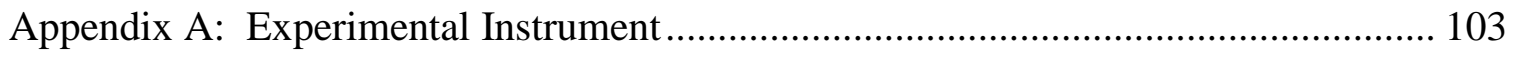

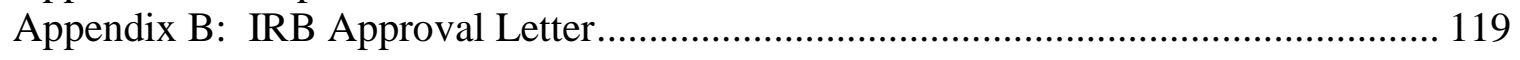




\section{LIST OF TABLES}

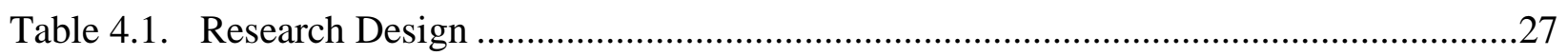

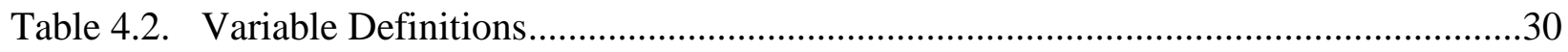

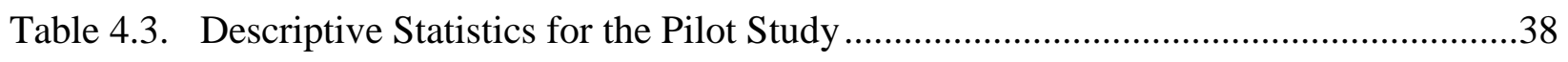

Table 5.1. Descriptive Statistics by Manipulation Failure.......................................................43

Table 5.2. Demographic and Participant Related Descriptive Statistics .................................47

Table 5.3. Outcome Related Descriptive Statistics............................................................50

Table 5.4. Spearman Correlation Report ........................................................................51

Table 5.5. Univariate Tests by Presentation Salience...........................................................57

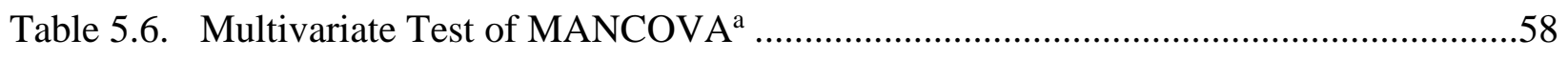

Table 5.7. ANCOVA Tests on Risk of Misstatement..........................................................60

Table 5.8. ANCOVA Tests on Impression of Investment .................................................64

Table 5.9. ANCOVA Tests on Likelihood of Stock Price Decrease / Increase .......................67

Table 5.10. ANCOVA Tests on Investment Amount ................................................................71

Table 6.1. Additional Tests on Risk of Misstatement by Sophistication..................................77

Table 6.2. Additional Analysis on Impression of Investment by Sophistication ......................79

Table 6.3. Additional Analysis on Likelihood of Stock Price Decrease/Increase by

Sophistication

Table 6.4. Additional Tests on Investment Amount by Sophistication ...................................83

Table 6.5. Additional Tests on Management Characteristics .................................................85

Table 7.1. Summary of the Results of the Hypotheses Tests ...............................................88 


\section{LIST OF FIGURES}

Figure 1. $\quad$ Research Model ....................................................................................... 19

Figure 2. $\quad$ Predictive Validity Framework (Libby Boxes).............................................. 20

Figure 3. Manipulation Check Questions.................................................................... 35

Figure 4. Means of Processing Fluency by Manipulation Check (Fail/Pass) ................... 45

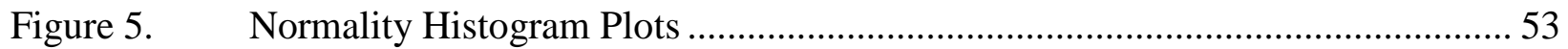

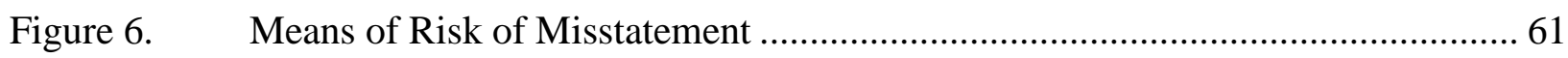

Figure 7. Means of Revised Impression of Investment............................................... 65

Figure 8. Means of Revised Likelihood of Stock Price Decline/Increase.......................... 68

Figure 9. Means of Revised Investment Amount..................................................... 72

Figure 10. Means of Risk of Misstatement by Sophistication .......................................... 76

Figure 11. Means of Revised Impression of Investment by Sophistication........................ 78

Figure 12. Means of Revised Likelihood of Stock Price Decrease/Increase by

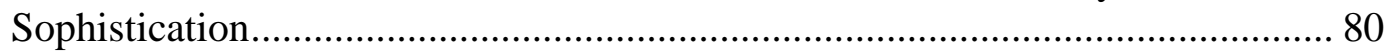

Figure 13. Means of Revised Investment Amount by Sophistication ................................. 82

Figure 14. Performance on ICW type Manipulation Check by Salience ............................. 86 


\begin{abstract}
This study investigates whether the current lack of structure of internal control weakness disclosures (a narrative about the reliability of the financial reporting system) leads nonprofessional investors to make differential investment decisions. Using the non-accelerated filer (smaller public company) setting, where nonprofessional investors are likely to consume unaudited internal control reports in their investing judgments and decisions, I examine two facets of internal control disclosure formats: presentation salience and disaggregation of material weaknesses. A 2 x 2 between-participants behavioral experiment was conducted with internal control presentation salience (bulleted vs. in-text) and disaggregation level (a single material weakness vs. a combination of multiple control deficiencies that is a material weakness). I find that nonprofessional investors reward companies that disclose internal control weaknesses more saliently. The results also indicate that disaggregation interacts with salience in that it increases the effect of salience on investing judgments such that salient (stealth) disclosure of a combination of control deficiencies is viewed more positively (negatively) than salient (stealth) disclosure of a material weakness. These findings are contrary to Rennekamp (2012) who finds that processing fluency in bad news leads to more negative investment judgements. Additional analyses indicated that the results related to management trust and credibility are consistent with prior literature. The findings contribute to academia and practice by shedding light on the importance that needs to be placed on the presentation format of internal control disclosures.
\end{abstract}




\section{INTRODUCTION}

With the intent of restoring investor confidence, the Sarbanes Oxley Act (SOX) of 2002 required public companies to evaluate and report on their internal control (IC) over financial reporting and to have this process verified by independent auditors. In addition to requiring management's assessment of internal controls, PCAOB Auditing Standard No. 5 (AS 5) requires the auditor to monitor the quality of internal control weakness (ICW) disclosures and to issue additional information clarifying the IC weakness when management has not properly discussed or represented the IC weakness in the 10-K filing (PCAOB 2007). However, in 2010, in response to complaints from the business community regarding compliance costs, the DoddFrank Act removed the independent audit of internal controls requirement for smaller publicly traded companies (non-accelerated filers). Since smaller firms operate in a setting where information asymmetry between investors and management is high, investors likely use complex disclosures related to operating risk and financial reporting risk such as IC reports. Nonprofessional investors particularly have difficulty extracting information from longer and more complex disclosures and suffer from location effects such as prominence and salience of diagnostic information (Elliott 2006; Files et al. 2009; Rennekamp 2012; Libby and Emett 2014). Nonprofessional investors are also important to study because in 1999, individual investors represented 45\% of stock ownership and had an increasing trend (Browning et al. 1999; Brink 2013). Therefore, it is important to study how the structure and content of internal control disclosures affect nonprofessional investors in the setting of non-accelerated filers. 
The need for a better disclosure structure in IC reports that improves comparability and the ease of specific ICW identification has been raised by researchers (Jonas et al. 2005; cf. Bedard et al. 2012b). However, Arnold et al. (2011) find that many nonprofessional investors (unlike professional ones) do not access the information within the currently available IC report, although such information has been documented to be useful for investing decisions (Rose et al. 2010; Asare and Wright 2012). This information access problem may partly arise from the obfuscation of a section in the report that identifies the control weaknesses and discusses the effect on the financial statements of each control weakness. Specifically, nonprofessional investors may not be able to extract the important diagnostic information out of the relatively long and unstructured portion of the management report on internal controls. I investigate whether the ICW information access problem for nonprofessional investors can be improved by structuring the presentation format of the IC report such that the diagnostic information (identification of the material weakness in internal controls) is more salient/readable. ${ }^{1}$ I also investigate how the structure of the IC report that has a higher processing fluency (perceived ease of processing/clarity) of ICW information may affect nonprofessional investors' judgments and decisions.

Increasing the salience of the IC report diagnostic information (identification of the material weakness in internal controls) as examined in this research is consistent with the SEC Plain English Handbook, in which the SEC specifically prescribes the use of “...bullets to list information whenever possible" and indicates that doing so "makes information easier to absorb in one quick glance...” (SEC 1998). Rennekamp (2012), who uses bullets as one of the ways to

\footnotetext{
${ }^{1}$ The part in the disclosure indicating the ICW presence and type of ICWs (diagnostic information) is typically a small proportion of the report relative to the rest of the disclosure which is non-diagnostic (such as the definition of an ICW, limitations of ICWs, SEC codification, identification of the framework used, etc.)
} 
operationalize readability, finds that the readability of textual disclosure information of both positive and negative financial performance amplifies nonprofessional investors' judgments in the respective direction. ${ }^{2}$ What is unclear in the extant literature is whether such findings will translate to the complex reporting setting of ICW disclosure, which involves a non-financial qualitative supplemental disclosure about internal control risks (subjective in nature). To add further complexity, investors have to infer the magnitudes of the risks of misstatement attributable to each disclosed ICW and the overall materiality of the misstatement used by each company.

In addition to salience, another aspect of ICW that is important to study is to study the composition of the ICW. An ICW, as defined in PCAOB AS No. 5, can be composed of one control deficiency (CD) that rises to the level of a material weakness (MW), or a combination of control deficiencies (each immaterial) that collectively pose a reasonable possibility of a material misstatement of the financial statements. Hence, a material weakness can be composed of multiple deficiencies with any mix of severity level (control deficiency, significant deficiency, or a material weakness) as long as the combination results in a risk of material misstatement. This difference in how the ICW is composed, hereafter ICW disaggregation type, makes the evaluation of ICWs a relatively complex task for an investor. Investors may react differently when evaluating a material weakness that is disclosed in an aggregate form as opposed to when it

\footnotetext{
${ }^{2}$ Rennekamp's manipulation for readability includes bulleted list along with three other textual features, such as clear bolded headings. In my experiment, I mirror information presentation salience observed in actual managerial reporting practices in 10-Ks by using bullets to point out the specific internal control weaknesses.
} 
is disaggregated into immaterial control deficiencies that rise to a material weakness when considered in aggregate. ${ }^{3}$

In this study, I investigate whether investors’ judgments differ for ICW disaggregation types that are either aggregated or disaggregated in material weakness disclosures and whether the salience of the ICW information disclosed interacts with disaggregation type. Prior studies that investigate the effect of disaggregation deal with the provision of detail that is quantifiable, i.e., the subparts are of known proportions. Moreover, studies in the psychology literature on unpacking effects have found conflicting results as to whether the whole is considered more or less than a combination of its subparts. The setting is unique and suitable for research because investors’ evaluating ICWs make investing judgments and decisions without the knowledge of private information regarding the disclosed weaknesses. Specifically, investors operate with no information on the probability of financial misstatement that is associated with each reported deficiency, whether each reported deficiency is assumed to be independent, and how the control deficiencies are valued by management.

The stream of archival research investigating a multitude of research questions and outcomes related to reporting MWs relies on the number and type of MWs disclosed by companies. The interest of academic research on the number and type of MWs provides additional motivation to study how investors' reaction is affected by the composition attribute of the IC report; that is, ICW disaggregation type in this study (Hammersley et al. 2008; Klamm and Watson 2009; Bedard and Graham 2011; Bedard et al. 2012a; Klamm et al. 2012). Prior

\footnotetext{
${ }^{3}$ Through a preliminary examination of a sample of the internal control reports for one hundred companies (not tabulated), I find that all of the aforementioned reporting practices mentioned are prevalent: IC reports with a high saliency ICW disclosure format in the form of a bulleted list and a low saliency ICW disclosure format presented within a paragraph (in-text), and IC reports with a MW disclosed as one MW (material) and IC reports with a MW discussed as a combination of CDs (immaterial).
} 
research does not delineate the difference between a material weakness that results from a combination of control deficiencies (disaggregated) and one that is disclosed as one material weakness (aggregated). Also, prior studies have not considered the effect of the presentation salience of ICW information disclosed by firms. By documenting that both the aggregation level and degree of presentation salience can influence the judgments and decisions of nonprofessional investors, this dissertation informs academics of the need to control for such differences in their research projects.

The results of this study inform standard setters as to how internal control weakness disclosures could be standardized and to inform managers of how nonprofessional investors perceive the alternative structures of ICW disclosures. Examining the interaction of disclosure presentation format and ICW disaggregation type is important because it identifies whether there could be unintended effects on nonprofessional investor judgments as a result of varied conventions and managerial stylistic preferences in IC reports.

The specific research questions investigated in this dissertation are:

1. What is the effect of presentation salience of ICWs on investing judgments (bullets vs. within text)?

2. What is the effect of disaggregation of ICWs (several control deficiencies vs. one weakness) on investing judgments?

A 2 x 2 between-participants behavioral experiment was conducted with internal control disclosure level manipulated as aggregated (one MW) and disaggregated (three CDs) and internal control disclosure presentation salience manipulated as stealth (in-text) and salient (bullets). The hypotheses in the study are tested using 164 nonprofessional investors who were recruited using a professional survey service. The experiment involved two stages. Participants were shown summary financial information of a small public company and asked three investing 
judgment questions in the first stage. In the second stage, participants were shown an IC report and asked to make revisions to their baseline judgments.

The results of the experiment indicate that salience of diagnostic internal control risk information on IC reports is viewed positively by investors. Specifically, participants in the salient ICW disclosure (bulleted) condition favorably revised their assessments of their overall impression of the investment as higher, their assessments of the risk of financial misstatement as lower, and their investing amount as higher than those in the stealth ICW disclosure (in-text) condition. The results also indicated that ICW disaggregation type interacts with salience, such that the effect of salience on the means investing judgments was stronger when the disclosed ICW disaggregation type is disaggregated (multiple control deficiencies). Investors' revisions indicated that they perceive the investment as having less downside risk when the ICW disaggregation type was a combination of multiple control deficiencies and was disclosed saliently (in-bullets) relative to when it was disclosed in a stealth format (in-text). Supplemental analyses on investors' assessments of management credibility and trust confirm the validity of the observed results and are consistent with management trust being affected by ICW disclosures.

This study is important because it aims to explain how investors may be affected by the relaxed ICW reporting environment resulting from the revised Dodd-Frank Act. Managers' use of alternative disclosure presentation formats and varying levels of reporting clarity have investing judgment consequences related to management trust and credibility that were uncovered through this dissertation. This study contributes to financial accounting literature that investigates the effect of presentation formats as well as disclosure disaggregation on investing behavior. These findings should be informative to academics who study internal control 
weaknesses using archival methods. Accounting researchers need to control for the presentation salience of the disclosed ICW and whether the ICW is composed of one material weakness or a combination of control deficiencies that aggregate to one material weakness. Finally, the study contributes to the unpacking effect research stream in psychology literature. The unpacking literature is largely mixed in terms of whether unpacking leads to information cue overweighting or underweighting.

The rest of the dissertation is organized as follows. Section 2 provides a review of the background and literature on internal control reporting under SOX, presentation of disclosures, and sophistication of investors. Section 3 presents the theoretical background and hypotheses. Section 4 describes the experimental method utilized in the study. Section 5 provides discussion of the results. Section 6 provides additional analyses of the results. Section 7 provides the conclusion and discussion of future research. 


\section{BACKGROUND AND LITERATURE}

\subsection{The Sarbanes-Oxley Act and Internal Control Reporting}

In the midst of several corporate reporting scandals around the turn of the $21^{\text {st }}$ century, the Sarbanes Oxley Act (SOX) was passed by Congress with the intent of restoring investor confidence in the reliability of corporate financial reporting. The legislation aimed to improve several corporate governance issues such as: auditor independence, auditor regulation, management accountability for corporate fraud, whistleblower mechanisms in organizations, the timely and controlled disclosure of corporate information, and most relevant to this proposal, internal control over financial reporting (US House of Representatives 2002; Ge and McVay 2005). The ongoing implication of SOX is that management has to continuously monitor and report quarterly on the effectiveness of internal controls (section 302), to assess and report annually to the public on the effectiveness of internal controls over financial reporting (section 404a), and for accelerated filers (typically corporations with public float greater than \$75 million) to have the auditor attest to management's annual assessments of the effectiveness of internal controls over financial reporting (section 404b) (US House of Representatives 2002). For an extensive literature on research related to internal control reporting under the Sarbanes Oxley Act see Schneider et al. (2009), Asare et al. (2012), and Coates IV and Srinivasan (2014).

\subsubsection{Consequences of Internal Control Weakness Disclosures}

During the past decade, the mandate for SOX reporting has led to considerable research that examines the consequences of the disclosure of internal control reports from both the preparers' and the report users' perspective (Schneider et al. 2009). From the report users' 
perspective, the legislation was expected to result in greater transparency and better corporate governance designed to reduce management misconduct. Research in this area investigates whether report users find value in the disclosure of internal control weaknesses by firms. Findings indicate that the stock market reacts negatively to the disclosure of ICWs as proxied by negative cumulative abnormal returns and higher cost of equity for disclosing firms (Hammersley et al. 2008; Gupta and Nayar 2007; Beneish et al. 2008; Ashbaugh-Skaife et al. 2009). Firms disclosing ICWs experience credit rating downgrades, higher interest rates for bank loans, and higher cost of debt, indicating that the credit market also finds ICW disclosures informative (Costello and Wittenberg Moerman 2010; Dhaliwal et al. 2011; Kim et al. 2011; Crabtree and Maher 2012). Consecutive disclosures of ICWs (i.e., failure to remediate existing material weaknesses) are also informative to equity and credit markets (Kim et al. 2011; Hammersley et al. 2012). Experimental investigations in this area find that perceptions of investing by individual investors, bank loan decisions and analyst assessments of firm risk are sensitive to ICW disclosures (Arnold et al. 2011; Rose et al. 2010; Asare and Wright 2012).

From the preparer's perspective, despite the documented benefits of SOX in terms of improvements in corporate governance and investor confidence, researchers and practitioners argue that the compliance costs of the legislation are not warranted (Krishnan et al. 2008a; Hochberg et al. 2009; Cohen et al. 2010; Cohen et al. 2012). Ghosh and Pawlewicz (2009) document an average audit fee increase of 74 percent after SOX adoption. When compared to firms without ICWs, firms that report ICWs have higher audit fees that remain high for up to two years after the ICW is remediated (Raghunandan and Rama 2006; Foster et al. 2007; Hoag and Hollingsworth 2011; Munsif et al. 2011; Keane et al. 2012). Overall, these compliance costs 
have driven some public US companies to go private and some foreign companies to delist from US equity markets (Engel et al. 2007; Doidge et al. 2010; Hostak et al. 2013).

The costliest portion of SOX, section 404(b), requires managements' assessments of the effectiveness of internal controls to be audited by the external auditor (Tackett et al. 2006; Krishnan et al. 2008b; Iliev 2010; Ahmed et al. 2010). As a result of continued pressure by the business community and lobbying of politicians regarding the heavy burden imposed on smaller companies, the original SOX section 404(b) adoption timeframe for smaller companies was postponed five times (Shepardson and Kinney 2011; Kinney Jr et al. 2013). In 2010, the DoddFrank Wall Street Reform and Consumer Protection Act permanently exempted smaller public companies (non-accelerated filers) from the section 404(b) internal control audit mandate (US House of Representatives 2010). Dodd-Frank was followed by the Jumpstart our Business Startups Act (JOBS ACT) in 2012, which further expanded the exemption from section 404(b) to new public companies (Emerging Growth Companies, hereafter EGCs) for the first five years of their operation (US House of Representatives 2012). ${ }^{4}$

\subsubsection{Is the Permanent Exemption of Non-accelerated Filers from Section 404(b) Warranted?}

“SOX compliance reduced the market value of small firms” (Iliev 2010, 1163). Many

small firms ended up leaving the public equity market because they did not want to bear the direct monetary compliance costs and indirect costs of inefficient allocation of human resources (Kamar et al. 2009). Research indicates that delaying the adoption of section 404(b) resulted in significant cost savings for small firms (Zhang 2007). Due to the compliance cost burden

\footnotetext{
${ }^{4}$ Emerging growth companies, according to the SEC, are new public companies that meet the following criteria: i) not large accelerated filers, ii) total market value under $\$ 1$ billion, iii) revenue under $\$ 1$ billion, and iv) debt issued in the past three years does not exceed \$1billion.
} 
argument, the Dodd-Frank and JOBs Acts have made small firms and EGC firms exempt from the internal control attestation 404(b) requirement. However, such exemption from regulation comes with economic consequences. It provides firms with incentives to stay small, resulting in undesirable actions such as "undertaking less investment, making more cash payouts to shareholders, reducing the number of shares held by non-affiliates, [and] making more bad news disclosures...” (Gao et al. 2009, 459).

\subsubsection{Certification of management's Internal Control reporting}

Researchers have started to investigate whether Dodd-Frank was justified in permanently exempting section 404(b) compliance for small firms (R. Mithu Dey and Sullivan 2012; Holder et al. 2013). These studies provide mixed results as to whether the exclusion will reduce management transparency regarding corporate governance. In a natural experiment with small US public companies, Kinney and Shepardson (2011) find that the group of companies adopting management internal control reporting (404a) had statistically and quantitatively similar rates of material weakness disclosure as the group adopting audited internal control reporting (404b), but with much lower audit fee increases. On the other hand, after the permanent exemption of SOX 404(b), Holder et al. (2013) document a significant deterioration in financial reporting quality among non-accelerated filers, measured by earnings management and accrual quality measures. In the absence of IC report auditor oversight, management may choose to be less transparent in ICW reporting.

The PCAOB Auditing Standard No. 5 (AS5) requires the auditor to publish a separate internal control report to discuss the ICW further if the auditor perceives the description of ICW in the management report to be insufficient or misleading to the report users (PCAOB 2007). In the absence of auditor certification of the internal control reporting, management can exercise 
higher discretion in the level of ICW detail it chooses to discuss/disclose. I investigate how investors respond to the internal control report in the absence of auditor verification, among nonaccelerated filers, and how they respond to manager's discretionary choices in internal control report formatting and ICW disaggregation (packaging) type.

\subsubsection{Classification of deficiencies in Internal Control by severity: Material Weaknesses and Control Deficiencies}

AS5 classifies deficiencies in internal control over financial reporting into three major categories: Material weakness, significant deficiency and control deficiency. This classification is based on the severity of the financial misstatement that may result from the failure of such controls. Material weaknesses, which are the most severe types of control deficiencies, are categories of control deficiencies that pose the risk that a financial misstatement that is above the organization's materiality threshold occurred or could be undetected. While material weaknesses are required to be disclosed to the public, the other two categories of control deficiencies are only reported to the audit committee and remain private, unless they are voluntarily disclosed. Listed below, in increasing order of severity, are the AS5 definitions of the severity categories for internal control deficiencies as stated in paragraphs A3, A11, and A7.

L. Control deficiency: A deficiency in internal control over financial reporting exists when the design or operation of a control does not allow management or employees, in the normal course of performing their assigned functions, to prevent or detect misstatements on a timely basis. (PCAOB 2007, para A3)

M. Significant deficiency: A significant deficiency is a deficiency, or a combination of deficiencies, in internal control over financial reporting that is less severe than a material weakness, yet important enough to merit attention by those responsible for oversight of the company's financial reporting. (PCAOB 2007, para A11)

H. Material weakness: A material weakness is a deficiency, or a combination of deficiencies, in internal control over financial reporting, such that there is a reasonable possibility that a 
material misstatement of the company's annual or interim financial statements will not be prevented or detected on a timely basis. (PCAOB 2007, para A7)

As noted above, material weaknesses may either be one deficiency that independently poses a risk of a material misstatement or a combination of control deficiencies that in aggregate pose a risk of material misstatement. I refer to these material weakness composition differences as ICW disaggregation type throughout this study. It is important to delineate the differences between control deficiencies and material weaknesses because the literature shows that the market reacts differently to these categories of weaknesses as well as the vagueness of the descriptions of the weaknesses (Hammersley et al. 2008).

\subsection{Incremental Information vs. Management Obfuscation}

The incremental information paradigm can be used to help explain management incentives to disclose ICW information. The paradigm assumes that managers are interested in their reputation and focus on providing value-relevant incremental information. Under this perspective, managers disclose more transparently to reduce information asymmetry and lower cost of capital (Merkl-Davies and Brennan 2007). The incremental information camp assumes a semi-strong form of market efficiency, whereas the impression management (management obfuscation) camp assumes a weak form of market efficiency or some inefficiency (MerklDavies and Brennan 2007).

The management obfuscation hypothesis on the other hand can be used to explain management incentives to reduce transparency relative to ICWs. It argues that managers have a disincentive to disclose adverse information and attempt to reduce the negative investor response that may arise from doing so (Merkl-Davies and Brennan 2007). This behavioral finance perspective assumes that investors have information processing limitations and can be misled. 
Managers will employ strategies to delay the timely processing of adverse information by increasing the information processing cost for such information (Bloomfield's "incomplete revelation hypothesis”) and hiding the information in complex disclosures (Bloomfield 2002; Li 2008). Readability research finds that managers tend to be self-serving and obfuscate the mandatory disclosure information to mitigate the negative investor responses in these unaudited disclosures (Libby and Emett 2014; Li 2008; Courtis 1998).

\subsubsection{Documented Lack of Internal Control Reporting Transparency}

Research in internal control reporting indicates that only about a quarter of all material weaknesses in internal control are detected by management while the rest are detected by the auditor on an annual internal control audit (Bedard and Graham 2011). Using working papers from small public audit firms, Bedard and her co-authors find that managers are more likely to under-classify material weaknesses (publicly reportable, higher severity control deficiencies) as significant deficiencies and control deficiencies (not publicly reported, lower severity). Their evidence suggests that in the absence of an internal control audit, managers may have more control deficiencies and significant deficiencies than material weaknesses and these may aggregate to a material weakness.

The number of IC reports issued in a given year that contain material weaknesses has been decreasing over time (Boritz et al. 2012). This decline in reporting ICWs may be a result of management's improvement in understanding and handling of ICs or management's reduced willingness to disclose ICWs. There is evidence to support the hypothesis that managers are not disclosing some material weaknesses to the public. Rice and Weber (2012) find that a significant proportion of firms that have financial restatements did not report ICWs in prior periods. Firms that report ICWs prior to a restatement are more likely to have class action lawsuits than those 
that hide ICWs until the restatement occurs, indicating that managers have an incentive to hide ICWs and delay their disclosure as long as possible (Coates IV and Srinivasan 2014; Rice et al. 2013).

\subsection{The structure of the Internal Control Report}

The final SEC ruling on SOX 404 requires companies to include the following in the internal control report of management (SEC 2003).

1. A statement of management's responsibility for establishing and maintaining adequate internal control over financial reporting for the company;

2. A statement identifying the framework used by management to conduct the required evaluation of the effectiveness of the company's internal control over financial reporting;

3. Management's assessment of the effectiveness of the company's internal control over financial reporting as of the end of the company's most recent fiscal year, including a statement as to whether or not the company's internal control over financial reporting is effective. The assessment must include disclosure of any "material weaknesses" in the company's internal control over financial reporting identified by management. Management is not permitted to conclude that the company's internal control over financial reporting is effective if there are one or more material weaknesses in the company's internal control over financial reporting; and

4. A statement that the registered public accounting firm that audited the financial statements included in the annual report has issued an attestation report on management's assessment of the registrant's internal control over financial reporting.

In this study, I classify these required pieces of information into two major parts:

diagnostic IC information and non-diagnostic IC information. I categorize item number 3 above as diagnostic IC information, because it communicates whether the IC report contains any ICWs. I categorize items 1, 2, and 4 above as non-diagnostic information because these contain standard language that is common across most reports and provide little informational value, even if the report has ICWs. ${ }^{5}$ The IC report is a narrative that typically ranges from half a page to a page in

\footnotetext{
${ }^{5}$ Item 4 for smaller reporting companies usually indicates that the information has not been audited by the external auditor due to being exempt by Dodd-Frank or the JOBS Act.
} 
length. Psychology research indicates that the implications of diagnostic information are weakened when it is accompanied by non-diagnostic information; a phenomenon known as the “dilution effect” (Nisbett et al. 1981). Nisbett et al. (1981) find that an increase in nondiagnostic cues decreases the ability of users to process the diagnostic cue. It is important to note that since the proportion of information disclosed that is diagnostic is much lower than the proportion of information that is non-diagnostic, report users may fail to access the diagnostic information that makes the IC report useful.

\subsection{Presentation Attributes of Disclosures}

Libby and Emett (2014) outline three presentation attributes of earnings disclosures that can affect judgment and decisions of report users: disaggregation, location, and attributes of narratives such as location and readability. The two presentation attributes that are most relevant to IC reports are disaggregation and readability.

\subsubsection{Disaggregation}

Disaggregation of information in accounting research has largely focused on quantitative items dealing with the financial statement items (Libby and Emett 2014). Disaggregation directly alters disclosed content by increasing the level of private information revealed by managers and primarily helps decision-makers extract relevant information from financial statements (Libby and Emett 2014). In this study, disaggregation refers to whether the ICW disclosed in the IC report is one material weakness or multiple control deficiencies that are individually immaterial, but rise to a material weakness in aggregate.

\subsubsection{Readability}

Accounting research in the area of readability of annual reports has investigated whether managers manipulate narrative reports to control report users' perceptions of firm performance 
(Merkl-Davies and Brennan 2007). In the Plain English Handbook, the SEC attempts to protect unsophisticated investors by requiring firms to disclose narratives in plain language that is easily understandable to the general public (SEC 1998). Nonetheless, the growing literature in this area of research indicates that "disclosure readability has only deteriorated over the past decade” (Libby and Emett 2014, 427; Li 2008).

The majority of the readability literature uses linguistic algorithms to perform content analysis of annual reports and archival investigations to link readability measures with firm performance and investor behavior (Merkl-Davies and Brennan 2007). The readability literature suggests that narratives have low readability scores and that other forms of disclosing, such as lists and tables may be more readable (Merkl-Davies and Brennan 2007; Adelberg 1979; Parker 1982). The literature also finds that firms with good performance have disclosures that are more readable while firms with poor performance tend to have disclosures that are less readable ( $\mathrm{Li}$ 2008; Courtis 2004). Lower readability of 10-K disclosures has also been linked to market under-reactions (You and Zhang 2009). Some of the common readability measures used in the literature include: the Fog index ${ }^{6}$, the Flesch index ${ }^{7}$, and disclosure length, but each of these proxies have received a fair share of criticism (Libby and Emett 2014; Merkl-Davies and Brennan 2007; Courtis 1998; Stone and Parker 2013).

Experimental accounting research in readability attempts to overcome the measurement error of readability proxies and to investigate the underlying mechanism by which investors are influenced by readability. Rennekamp (2012) manipulates readability by using guidelines from

\footnotetext{
${ }^{6}$ Fog index is a measure of readability that originated in the computational linguistics literature. Fog index uses a formula that combines the number of complex words with the number of words per sentence. Li (2008)

${ }^{7}$ Flesch index is a measure of readability that is similar to the Fog index but with a slightly different formula that uses the words per sentence and syllables per word to calculate readability. Li (2008)
} 
the SEC Plain English Handbook and finds that investors respond more positively (negatively) to good (bad) news when the readability of the narrative disclosure is higher. Rennekamp (2012) finds that processing fluency and subconscious feelings of ease in processing the information explain the relation between small investor decisions and readability of earnings release disclosures. Tan et al. (2013) also conducted a behavioral experiment and find that investors’ performance judgments are more magnified by the readability of earnings release disclosures when the information regarding firm's meeting or beating of prior benchmark performance is inconsistent with the firm’s earnings trend. Tan et al. (2013) find that the relation between investing and readability is explained by feelings of processing fluency and increased understandability of the disclosure. 


\section{HYPOTHESES DEVELOPMENT}

I investigate the effects of presentation format and disaggregation of ICWs in SOX 404 reports using a framework adapted from Maines and McDaniel (2000) and Hogarth (1987). The framework, depicted on Figure 1, proposes that the IC presentation format affects the level to which users access the ICW section in the IC report, their evaluation of the ICW severity, and their weighting of the likelihood of the ICW causing material misstatement. I propose that these assessments influence investors' perceptions of the riskiness of the investment and investing judgments. As I propose in the framework, the acquisition, evaluation, and weighting of the ICW information will depend on the IC presentation format, leading to differences in misstatement risk and investing judgments. In the framework, IC report presentation format represents both the level of presentation salience of the ICW information in the IC report and the extent to which the ICW section is disaggregated. The conceptual and operational variables used in the proposed study are presented below on Figure 2.

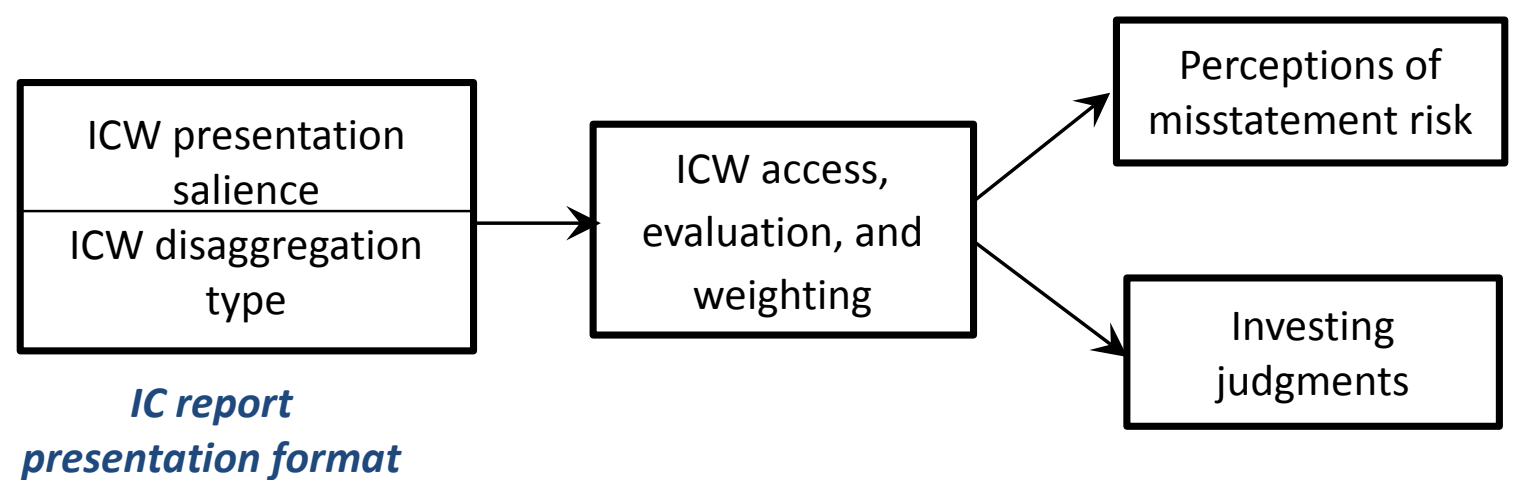

Figure 1. Research Model 


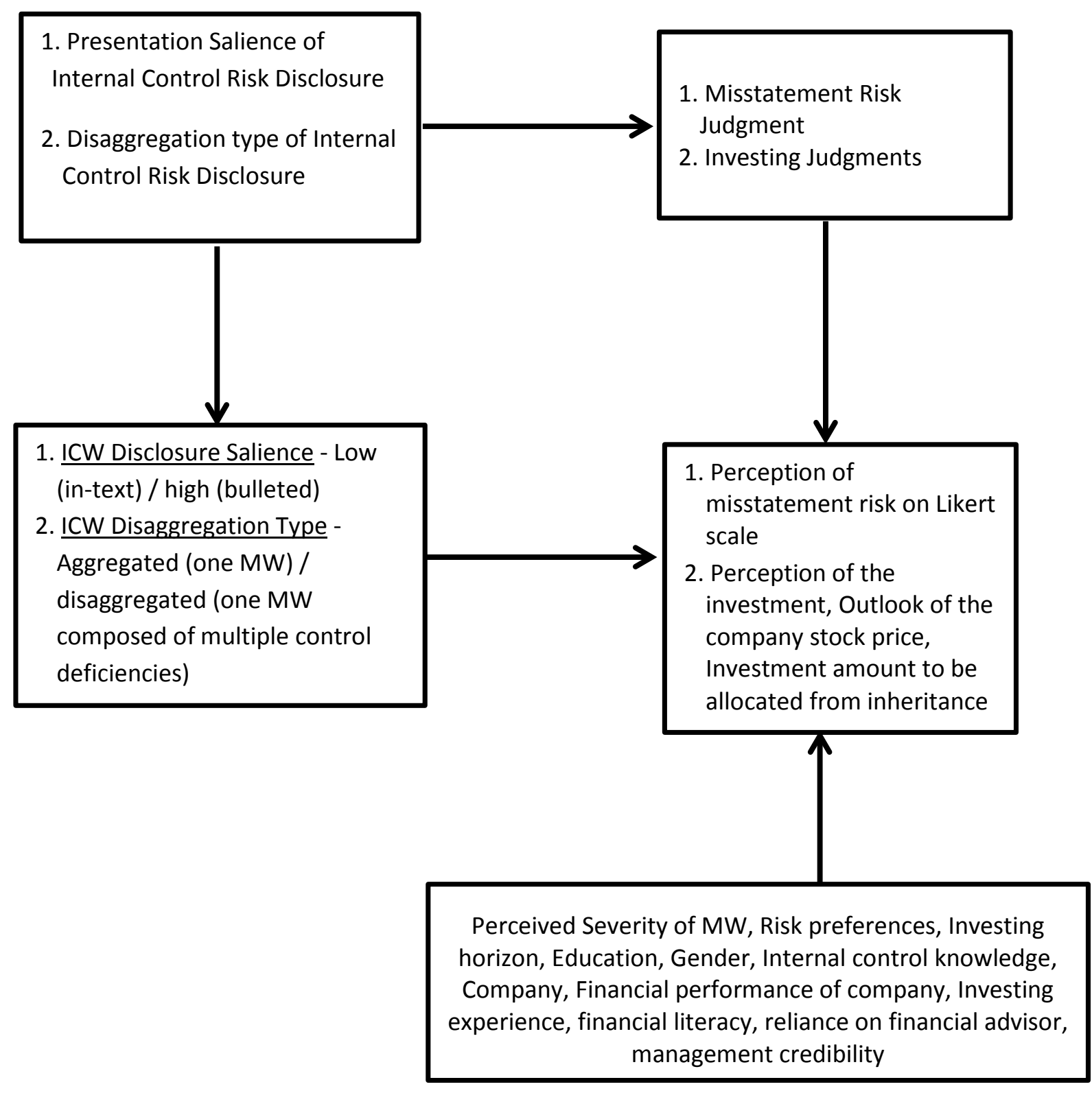

Figure 2. - Predictive Validity Framework (Libby Boxes) 


\subsection{Presentation Salience of ICW Information in IC Reports}

\subsubsection{Accessibility of ICW Information in IC Reports}

Nonprofessional investors are more likely to use a sequential search strategy, are more likely to get confused and fatigued by long disclosures, and are more likely to struggle to extract information from these disclosures than professional investors (Rennekamp 2012; Libby and Emett 2014; You and Zhang 2009; Maines and McDaniel 2000; Miller 2010). Unlike professional investors who have well formulated mental models, nonprofessional investors may not be able to easily extract the diagnostic ICW information from the IC report. It is reasonable to expect nonprofessional investors to be fatigued by long and unstructured narrative disclosures such as IC reports. In support of this notion, Arnold et al. (2011) document that only 59 percent of their nonprofessional participants were able to access the ICW information versus 72 percent of their professional investors.

In addition to fatigue effects that hinder nonprofessional investors' ability to extract information from disclosures, individuals have cognitive limitations and aim to reduce effort associated with judgments and decisions by using selective (heuristic) search (Tversky and Kahneman 1974; Simon 1990; Shah and Oppenheimer 2008). They use information in its current form to avoid information processing costs even when reconfiguration of this information is needed to make better judgments (Payne 1982; Clor-Proell et al. 2014). Presentation attributes such as disclosure prominence have been shown to moderate the accessibility of information in press releases (Files et al. 2009). Clor-Proell et al. (2014) find that presentation salience helps nonprofessional investors incorporate otherwise costly information into their judgments. Bowen et al. (2005) also show that the emphasis placed on pro-forma earnings in quarterly press releases leads to stronger market reactions. 


\subsubsection{Processing Fluency of ICW Information in IC Reports}

Processing fluency or the subjective ease with which information can be processed can affect how people weight information cues (Shah and Oppenheimer 2007). When information is perceived as easy to process, people assign it more weight than when it is perceived as hard to process (Shah and Oppenheimer 2007). Processing fluency has been manipulated in several ways in the literature ( see Alter and Oppenheimer 2009). Rennekamp (2012) manipulates processing fluency using the SEC's Plain English Handbook as a guide to design her experimental materials using features such as clear headings, appropriate layout, tables, and bullet points. Therefore, ICW disclosures with higher salience are expected to have higher processing fluency.

The literature is unclear on whether processing fluency has a non-directional amplifying influence or positive influence on the information set disclosed. That is, investors reading an IC report that includes a salient presentation format of ICWs (displayed in bullets) may either view the company as a riskier investment, resulting in lower perceptions of investing likelihood than investors reading an IC report that has a stealth presentation format of ICWs (displayed within the text), or they may view the salient report as more transparent and view the company as a less risky investment, resulting in higher perceptions of investing likelihood than investors reading a stealth report.

Two relatively recent studies in the accounting domain have linked processing fluency with the effect of readability of earnings disclosures on investing decisions of nonprofessional investors (Rennekamp 2012; Tan et al. 2013). Tan et al. (2013) find that readability increases investors' understanding of a firms’ positive and negative performance, which leads to changes in their investing judgments, particularly when firm performance is not easily determinable. 
Rennekamp (2012) finds that processing fluency of a disclosure increases investors' reliance on such disclosure However, in the psychology domain, Shah and Oppenheimer (2007) demonstrated that nonprofessional investors were less likely to recommend investments that were associated with names of brokerage firms that were disfluent than investments that were associated with brokerage firms that had fluent names. Their result indicates that perceived ease of processing may positively influence judgments independent of its content and valence.

On the one hand, usage of bullets to identify the ICWs enhances readability and the ease with which the diagnostic ICW information can be extracted and accessed for information processing. This enhanced access to the diagnostic ICW information will initiate the decision process so that the user can evaluate the ICW information cue and assign weights to those cues. The adapted Maines and McDaniel (2000) ICW presentation format framework, would predict that high salience leads to high ICW information access, ICW information evaluation (bad news), and high ICW information weighting. This follows that investors may perceive that the information they were able to extract was important enough to be disclosed and that management may have a severe internal control issue. Rennekamp (2012) documents increased weighting of the information cue regardless of whether the news was good or bad. Rennekamp's findings support the idea that is predominant in the readability literature that implies that managers' obfuscation of disclosures to mitigate negative investor responses is warranted since investors overreact to negative news when it is more readable.

On the other hand, increased information access and processing fluency that results from disclosing saliently by using bullets to identify ICWs (seemingly bad news) can lead management to be perceived as more transparent and credible. Rennekamp (2012) documents a positive relation between processing fluency and management credibility (a variable formed by 
combining assessments of management trust and competence). Rose et al. (2010) indicate that management trust is an important variable for nonprofessional investor judgments when analyzing companies with internal control weakness disclosures. This indicates the ICW disclosure setting may be a setting that management may wish to disclose transparently to maintain its reputation and lower cost of capital. Rose et al. (2010) find that management trust was related to lower risk of investing. When presentation salience of ICW information is high, investors are likely to attribute higher presentation salience to higher perceptions of management's credibility, which in turn is expected to positively affect their investing judgments and evaluations of misstatement risk. Accordingly, increased processing fluency in disclosing ICW information can signal to investors that management has a good handle on the internal controls, rather than when management is disclosing ICWs in a less salient manner. Therefore, the negative investor reaction to higher processing fluency of earnings information in the "bad news” setting of Rennekamp (2012) is not expected to translate to the ICW setting where presentation salience can be attributed to positive management characteristics and IC competence. Therefore, I formally state my hypotheses as follows:

H1. Higher presentation salience of internal control weaknesses will mitigate the high perceived risk of misstatement that results from the disclosure of internal control weaknesses.

H2. Higher presentation salience of internal control weaknesses in an internal control report will lead to more favorable investing judgements.

\subsection{Disaggregation of ICW Information in IC Reports (Unpacking)}

Accounting research has studied the effect of disaggregation of quantitative financial information in several contexts and determined that disaggregation leads to the provision of additional information that users find beneficial (Libby and Emett 2014). Disaggregation of 
qualitative information, which has been extensively investigated in the psychology literature, can also lead to unpacking effects that increase information weighting (Shah and Oppenheimer 2011). Unpacking effects of this form occur when people assign higher probability to an event when the event is broken down into its sub parts (Tversky and Koehler 1994). Tversky and Koehler's support theory explains that providing details of an event leads people to more easily support their hypothesis that there is a higher likelihood and frequency with which that event occurs (Van Boven and Epley 2003).

Unpacking effects that increase information weighting can also be explained by the numerosity heuristic (Pelham et al. 1994). Numerosity is a heuristic cue that people use when evaluating multiple items. The use of the numerosity heuristic misleads people to judge weights of items based on how many items are available (Pelham et al. 1994). Disaggregated components of ICWs may be over-weighted by investors if their numerosity heuristic leads them to simply count the number of items listed in the ICW section.

Contrary to the majority of the findings in the psychology literature on unpacking effects, recent work on unpacking effects finds that unpacking does not always lead to a higher assignment of weights to cues that are presented in disaggregated formats (Redden and Frederick 2011). This may also be the case with ICW disclosures because unpacking leads to multiple control deficiencies that are of lower severity than material weaknesses. Investors may either ignore that the deficiencies are material in aggregate or underweight each deficiency. In support of this notion, Redden and Frederick (2011) perform multiple psychology experiments and find that greater detail (unpacking) reduces perceived probabilities assigned to events. Redden and Frederick (2011) provide the theoretical explanation for their findings by indicating that disaggregation decreases processing fluency. Their explanation suggests due to processing 
fluency that is affected by both salience and disaggregation, the factors may have interactive effects.

Rose et al. (2010) find that investors viewed explanation detail, another form of transparency, as more useful and assigned more trust to management when the type of ICW was one that was pervasive and needed further explanation. Due to the numerosity heuristic and predictions of support theory, investors viewing multiple control deficiencies are likely to overweight the control weakness and view it as relatively severe and worthy of being disclosed transparently. As such, when the type of weakness disclosed is composed of multiple control deficiencies, investors should penalize management when it discloses the weakness in a stealth manner and reward management when it discloses the weakness saliently. This effect is not expected to occur in the case of one material weakness since the overweighting does not occur through numeracy or support theory's predictions.

Based on the predominant findings in the psychology literature on unpacking that finds that unpacking increases information weighting, support theory, numerosity heuristic, and the findings of (Rose et al. 2010), I formally hypothesize the interaction between salience and disaggregation resulting from the unpacking effect of disaggregation of ICWs as follows:

H3. The negative relation between salience and the risk of misstatement is greater when a material weakness is disaggregated as a combination of control deficiencies than when it is aggregated as a single material weakness.

H4. The positive relation between salience and investing judgments is greater when a material weakness is disaggregated as a combination of control deficiencies than when it is aggregated a single material weakness. 


\section{METHOD}

\subsection{Experimental Design}

A 2 x 2 between-participants fully randomized factorial experiment was conducted using nonprofessional investors recruited by a professional survey service. The factors manipulated are ICW disaggregation type (disaggregated - combination of control deficiencies / aggregated one material weakness) and ICW presentation salience (salient - presented in a bulleted form / stealth - presented in-text). The experimental design is presented in Table 4.1.

\begin{tabular}{|c|c|c|c|}
\hline \multirow{2}{*}{\multicolumn{2}{|c|}{$\begin{array}{l}2 \times 2 \text { Between-participants experiment } \\
\text { utilizing nonprofessional investors }\end{array}$}} & \multicolumn{2}{|c|}{ ICW presentation salience } \\
\hline & & $\begin{array}{l}\text { Low / Stealth } \\
\text { (in-text) }\end{array}$ & $\begin{array}{l}\text { High /Salient } \\
\text { (bullets) }\end{array}$ \\
\hline \multirow{2}{*}{$\begin{array}{c}\text { ICW } \\
\text { disaggregation } \\
\text { type }\end{array}$} & $\begin{array}{c}\text { Aggregated (Packed) - } \\
\text { One MW }\end{array}$ & (1) & (2) \\
\hline & $\begin{array}{c}\text { Disaggregated } \\
\text { (Unpacked) - One MW } \\
\text { that is a combination of } \\
\text { control deficiencies }\end{array}$ & (3) & (4) \\
\hline
\end{tabular}

\subsection{Independent Variables}

The independent variables are ICW disaggregation type, ICW presentation salience, and investor type. ICW disaggregation type is manipulated as disaggregated control deficiencies and aggregated material weakness. I operationalize disaggregation by including several control deficiencies that are equivalent to one material weakness on the IC report. I operationalize aggregation by including one material weakness in the IC report. ICW disclosure presentation salience is manipulated by displaying the ICW in a salient format or in a less salient "stealth" 
format. I operationalize the salient manipulation by displaying the ICW in a bulleted format and the stealth manipulation by displaying the ICW in a narrative in-text format. ${ }^{8}$

\subsection{Dependent Variables}

The dependent variables are perceptions of likelihood of stock price decrease/increase, impression of investment, invested amount, and risk of misstatement. Likelihood of stock price decrease/increase is measured on a 15 point scale (-7 High likelihood of decline, 0 No change, +7 High likelihood of increase) by asking participants the following risk measure adapted from Rose et al. (2010): “what is your assessment of the likelihood of a moderate stock price change (1-10\%) within the next year?” Overall impression of investment is a question taken from (Kaplan et al. 2015) and is measured on a seven point Likert scale (1-Very unfavorable, 7-Very favorable). The Overall impression of investment question asked of participants is: "What is your overall impression of ANZ Technologies as an investment?” The invested amount dependent variable is adopted from (Farkas and Murthy 2014) and is measured by asking participants to assume they had inherited $\$ 10,000$ from a distant relative and that they wanted to spend their inheritance on stocks. Participants are then asked to specify an amount between $\$ 0$ and \$10,000 that they would like to invest in the company’s stock. Risk of misstatement was collected using a question adapted from (Asare and Wright 2012): “What is the risk that ANZ's financial statements contain a material misstatement?” (0- No chance of a material misstatement, 10-Highly likely a material misstatement).

\footnotetext{
${ }^{8}$ Rennekamp's manipulation for readability included bulleted list along with three other textual features, such as clear bolded headings. In my experiment, I mirror information presentation salience observed in actual managerial reporting practices by using bullets to point out the specific internal control weaknesses.
} 


\subsection{Covariates}

Several potential covariates are measured in a post experimental questionnaire. Since risk assessments are likely to be correlated with inherent risk preferences, individual propensity to take risk is measured using three risk preference questions from Van Rooij et al. (2011). Rank of risk is assessed by the number of times the person goes with a risky option (0-Risk averse, 3Risk seeking). See Table 4.2 for further detail on the risk preference questions. Education is a seven scale ordinal variable that is measured by asking participants’ level of education (1-No schooling, 2-High school degree, 3-Some college credits, less than two years of full time course work, 4-Associate degree, or over two years of full time course work, 5-Bachelor's degree, 6Master's degree, 7-Doctorate degree). Participants are also asked whether they had a degree in the area of Business Administration and how many accounting and finance courses they have taken. Investing horizon is another variable that is collected to determine whether participants are interested in a long term profit or a short term gain from the investing activity. Investing horizon is measured using a nine point Likert scale (1-short horizon, 9-long horizon).

In their review of literature on presentation formats, Libby and Emett (2014) indicate that financial literacy and investing experience may work to mitigate the effects of poor readability on investing. I control for financial literacy by asking 11 questions from an advanced financial literacy scale that was developed by Van Rooij et al. (2011). Another potential covariate for nonprofessional investors is reliance on financial advisors. Familiarity of 10-k reports, selfassessed familiarity, and reliance on internal controls is also collected. Following Rose et al. (2010), an understanding check question on internal controls is also measured in the post experimental questionnaire to ensure that a majority of participants understand the company risks 
that are related to an incidence of internal control weakness disclosures. The variables used in the study are listed in Table 4.2.

Table 4.2. Variable Definitions

Panel A. Dependent and independent variables

I. Main dependent variables

\begin{tabular}{|c|c|}
\hline $\begin{array}{l}\text { 1) Risk of } \\
\text { misstatement }\end{array}$ & $\begin{array}{l}\text { Risk that financial statements contain a material misstatement }(0 \text { - } \\
\text { No chance of a material misstatement, } 10 \text { - Highly likely a material } \\
\text { misstatement) }\end{array}$ \\
\hline $\begin{array}{l}\text { 2) Revised impression } \\
\text { of investment }\end{array}$ & $\begin{array}{l}\text { Revised impression of company as an investment (1-Very } \\
\text { unfavorable, 7-Very favorable) }\end{array}$ \\
\hline $\begin{array}{l}\text { 3) Revised likelihood } \\
\text { of stock price } \\
\text { decrease/increase }\end{array}$ & $\begin{array}{l}\text { Revised Likelihood of moderate stock price change (1-10\%) } \\
\text { within one year (-7 High likelihood of decline, } 0 \text { No change, }+7 \\
\text { High likelihood of price increase), recoded to a } 15 \text { point scale for } \\
\text { analyses (1-15) }\end{array}$ \\
\hline $\begin{array}{l}\text { 4) Revised invested } \\
\text { amount }\end{array}$ & $\begin{array}{l}\text { Revised investment amount on company stock to be allocated } \\
\text { from a } \$ 10,000 \text { inheritance, free response }(0-\$ 10,000)\end{array}$ \\
\hline \multicolumn{2}{|c|}{ II. Baseline for dependent variables (to be included as covariates) } \\
\hline $\begin{array}{l}\text { 1) Baseline impression } \\
\text { of investment }\end{array}$ & $\begin{array}{l}\text { Baseline impression of company as an investment (1-Very } \\
\text { unfavorable, 7-Very favorable) }\end{array}$ \\
\hline $\begin{array}{l}\text { 2) Baseline likelihood } \\
\text { of price } \\
\text { decline/increase }\end{array}$ & $\begin{array}{l}\text { Baseline likelihood of moderate stock price change (1-10\%) } \\
\text { within one year ( }-7 \text { High likelihood of decline, } 0 \text { No change, }+7 \\
\text { High likelihood of increase), recoded to a } 15 \text { point scale for analyses } \\
(1-15)\end{array}$ \\
\hline $\begin{array}{l}\text { 3) Baseline invested } \\
\text { amount }\end{array}$ & $\begin{array}{l}\text { Baseline investment amount on company stock to be allocated } \\
\text { from a } \$ 10,000 \text { inheritance, free response }(0-\$ 10,000)\end{array}$ \\
\hline \multicolumn{2}{|l|}{ III. Independent variables } \\
\hline $\begin{array}{l}\text { 1) Presentation } \\
\text { Salience }\end{array}$ & $\begin{array}{l}\text { Presentation salience manipulation (0- Stealth/In-text narrative, 1- } \\
\text { Salient/Bulleted list) }\end{array}$ \\
\hline $\begin{array}{l}\text { 2) ICW disaggregation } \\
\text { type }\end{array}$ & $\begin{array}{l}\text { Disaggregation manipulation (0- Disaggregated/Multiple CDs, 1- } \\
\text { Aggregated/MW) }\end{array}$ \\
\hline \multicolumn{2}{|c|}{ Panel B. Demographic and post-experimental questionnaire variables } \\
\hline \multicolumn{2}{|c|}{ III. Independent variables } \\
\hline 1) Risk preference & $\begin{array}{l}\text { Rank of risk assessed by the number of times the person goes with } \\
\text { a risky option (0-Risk averse, 3- Risk seeking). I use a risk scale } \\
\text { that has three questions developed by Van Rooij et al. (2011). A } \\
\text { display logic was used to show either RQ2 or RQ3 based on } \\
\text { participants' responses RQ1. If the participant selected "yes" } \\
\text { (risky option) for RQ1, RQ2 is displayed, otherwise if "no" or "I } \\
\text { don't know" are selected to indicate a safe choice, RQ3 is }\end{array}$ \\
\hline
\end{tabular}




\begin{tabular}{|c|c|}
\hline & $\begin{array}{l}\text { displayed. Therefore, each participant was exposed to only two } \\
\text { risk questions. } \\
\text { “RQ1. Suppose that you are the only income earner in the family, } \\
\text { and you have a good job guaranteed to give you (your family) } \\
\text { your current income every year for life. You are given the } \\
\text { opportunity to take a new, equally good job, with } 50 \% \text { chance it } \\
\text { will double your (family) income and a 50\% chance that it will cut } \\
\text { your (family) income by a third. Would you take the new job? } \\
\text { (Yes/No/I don't know) (Van Rooij et al. 2011, 470)” } \\
\text { "RQ2. Suppose the chances were 50\% that it would double your } \\
\text { (family) income, and 50\% that it would cut it in half. Would you } \\
\text { take the new job? (Yes/No/I don’t know) (Van Rooij et al. 2011, } \\
471 \text { )” } \\
\text { "RQ3. Suppose the chances were } 50 \% \text { that it would double your } \\
\text { (family) income and 50\% that it would cut it by } 20 \text { percent. } \\
\text { Would you then take the new job? (Yes/No/I don’t know) (Van } \\
\text { Rooij et al. 2011, } 471 \text { ) }\end{array}$ \\
\hline 2) Financial literacy & $\begin{array}{l}\text { Correct number of responses on } 11 \text { "advanced” financial literacy } \\
\text { scale questions adopted from Van Rooij et al. (2011). Please see } \\
\text { their paper to see a complete list of their "advanced” financial } \\
\text { literacy questions. }\end{array}$ \\
\hline $\begin{array}{l}\text { 3) Self-assessed IC } \\
\text { understanding }\end{array}$ & $\begin{array}{l}\text { Self-reported understanding of internal controls (1-Low level of } \\
\text { understanding, 7-High level of understanding) }\end{array}$ \\
\hline $\begin{array}{l}\text { 4) ICFR influences my } \\
\text { investing decision }\end{array}$ & $\begin{array}{l}\text { The extent to which IC disclosures affect the participants' } \\
\text { investing decisions (1-No, Internal control disclosures do not } \\
\text { affect my investing decisions, 7-Yes, Internal control disclosures } \\
\text { affect my investing decisions) }\end{array}$ \\
\hline $\begin{array}{l}\text { 5) Familiarity with } \\
10 \mathrm{~K} \text { reports }\end{array}$ & $\begin{array}{l}\text { Familiarity with annual (10-K) report of public companies (1- Not } \\
\text { familiar, 7- Very familiar) }\end{array}$ \\
\hline 6) Investment horizon & $\begin{array}{l}\text { Investment horizon (1-Short term investment horizon, 9-Long } \\
\text { term investment horizon) }\end{array}$ \\
\hline 7) Investing experience & $\begin{array}{l}\text { The number of years it has been since the participant began buying } \\
\text { or selling individual stocks on his/her own (text entry) }\end{array}$ \\
\hline $\begin{array}{l}\text { 8) Reliance on } \\
\text { financial advisor }\end{array}$ & $\begin{array}{l}\text { Reliance on financial advisor/broker/planner for investments ( } 1 \text { - I } \\
\text { manage all my investments on my own, 7-I let my financial } \\
\text { advisor/planner handle all my investments) }\end{array}$ \\
\hline 9) Investor inactive & $\begin{array}{l}\text { The number of months that have passed since the participant last } \\
\text { actively bought or sold stocks in the stock market (text entry) }\end{array}$ \\
\hline 10) Trading frequency & $\begin{array}{l}\text { Number of trades per year (1- Less than } 10 \text { trades per year, } 2-10 \\
\text { to } 100 \text { trades per year, } 3-100 \text { to } 1000 \text { trades per year, } 4 \text { - Over } \\
1,000 \text { trades per year) }\end{array}$ \\
\hline 11) Work experience & Number of years of professional work experience (text entry) \\
\hline 12) Education rank & $\begin{array}{l}\text { Highest level of education (1-No schooling, 2-High school } \\
\text { degree, 3-Some college credits, less than two years of full time }\end{array}$ \\
\hline
\end{tabular}




\begin{tabular}{|c|c|}
\hline & $\begin{array}{l}\text { course work, 4-Associate degree, or over two years of full time } \\
\text { course work, 5-Bachelor's degree, 6-Master's degree, 7-Doctorate } \\
\text { degree) }\end{array}$ \\
\hline 13) Business degree & Business degree (1-Yes, 0-No) \\
\hline 14) Accounting courses & Number of accounting courses taken (text entry) \\
\hline 15) Finance courses & Number of finance courses taken (text entry) \\
\hline $\begin{array}{l}\text { 16) Severity of overall } \\
\text { ICW reported }\end{array}$ & $\begin{array}{l}\text { Severity of the overall combination of CDs/single MW reported in } \\
\text { the IC report (1-Very low severity, 7-Very high severity) }\end{array}$ \\
\hline $\begin{array}{l}\text { 17) Likelihood of } \\
\text { material error of } \\
\text { overall ICW } \\
\text { reported }\end{array}$ & $\begin{array}{l}\text { Likelihood of the overall combination of CDs/single MW to cause } \\
\text { material errors ( } 0 \% \text { - No chance, } 100 \% \text { - Certain to cause material } \\
\text { errors) }\end{array}$ \\
\hline 18) Severity of ICDs & $\begin{array}{l}\text { Mean of the severity assessments on the three IC deficiencies } \\
\text { presented in the disaggregated conditions (1-Very low severity, 7- } \\
\text { Very high severity) }\end{array}$ \\
\hline $\begin{array}{l}\text { 19) Likelihood of } \\
\text { material error of } \\
\text { ICDs }\end{array}$ & $\begin{array}{l}\text { Mean of assessments of likelihood of internal control deficiency to } \\
\text { cause material errors on the three IC deficiencies presented in the } \\
\text { disaggregated conditions ( } 0 \% \text { - No chance, } 100 \% \text { - Certain to } \\
\text { cause material errors) }\end{array}$ \\
\hline 20) Processing fluency & $\begin{array}{l}\text { Response to the question "The specific section discussing the } \\
\text { internal control issue(s) disclosed was clearly presented/easy to } \\
\text { understand" (1-Strongly disagree, 7- Strongly agree) }\end{array}$ \\
\hline $\begin{array}{l}\text { 21) Reliability of IC } \\
\text { report }\end{array}$ & $\begin{array}{l}\text { The extent that participants thought they could rely on the internal } \\
\text { control report (1- Not at all, 7- Completely) }\end{array}$ \\
\hline $\begin{array}{l}\text { 22) Management } \\
\text { competence }\end{array}$ & $\begin{array}{l}\text { Assessment of management competence in preparing and } \\
\text { communicating company disclosures to the public (1-Strongly } \\
\text { disagree, 7- Strongly agree). }\end{array}$ \\
\hline $\begin{array}{l}\text { 23) Management } \\
\text { trustworthiness }\end{array}$ & $\begin{array}{l}\text { Assessment of management trustworthiness in preparing and } \\
\text { communicating company disclosures to the public (1-Strongly } \\
\text { disagree, 7- Strongly agree) }\end{array}$ \\
\hline $\begin{array}{l}\text { 24) CD vs MW severity } \\
\text { knowledge }\end{array}$ & $\begin{array}{l}\text { 1-CDs are much more severe than MWs, 4-CDs and MWs are of } \\
\text { equal severity, 7- MWs are much more severe than CDs }\end{array}$ \\
\hline $\begin{array}{l}\text { 25) MD\&A reading } \\
\text { frequency }\end{array}$ & $\begin{array}{l}\text { The frequency with which the participant reads the Management } \\
\text { Discussion and Analysis section of a company's annual report (1- } \\
\text { Never read, 2-Sometimes read, 3-Often read, 4-Always read) }\end{array}$ \\
\hline $\begin{array}{l}\text { 26) Auditor's Report } \\
\text { reading frequency }\end{array}$ & $\begin{array}{l}\text { The frequency with which the participant reads the Auditor's } \\
\text { Report section of a company's annual report (1- Never read, 2- } \\
\text { Sometimes read, 3-Often read, 4-Always read) }\end{array}$ \\
\hline $\begin{array}{l}\text { 27) Notes reading } \\
\text { frequency }\end{array}$ & $\begin{array}{l}\text { The frequency with which the participant reads the Notes to the } \\
\text { Financial Statements section of a company's annual report (1- } \\
\text { Never read, 2-Sometimes read, 3-Often read, 4-Always read) }\end{array}$ \\
\hline $\begin{array}{l}\text { 28) IC understanding } \\
\text { check }\end{array}$ & $\begin{array}{l}\text { How does the presence of internal control weaknesses affect a } \\
\text { company's financial reporting system? (1- Negative effect, 7- } \\
\text { Positive effect) }\end{array}$ \\
\hline
\end{tabular}




\section{Table 4.2. Variable Definitions (continued)}

Did management indicate that the internal control over financial

29) IC report

effectiveness check reporting was not effective? (1- Yes, the company's internal control was not effective, 2-No, the company’s internal control was effective, 3-I do not know)

\subsection{Participants}

Participants used to test the hypotheses were 164 U.S. nonprofessional investors recruited through a professional survey service. The target sample size of 160 nonprofessional investors was determined after performing an ex-ante power analyses to calculate the sample size for the 2 x 2 design based on expected means and standard deviation for the expected effect size. ${ }^{9}$ To confirm that participants recruited were indeed nonprofessional investors they were prescreened. To be included in the experiment participants answered "yes" to the question: "Have you bought or sold individual stocks in the past two years?” and answered "no” to the question: "Have you bought or sold individual stocks as part of your profession (e.g. broker, analyst, etc.)?”10 Nonprofessional investors were compensated an undisclosed incentive by the survey collection company for their participation. ${ }^{11}$

\subsection{Tasks and Procedures}

Participants recruited using the professional survey service were directed to the online experimental instrument. The experimental task began with participants reading background information including a brief explanation of material weaknesses, a description of how the ICW disaggregation type can differ, a description of the industry condition, and a brief description of

\footnotetext{
${ }^{9}$ Rennekamp (2012) used 234 Amazon Mechanical Turk participants in a 2x2 design and reported similar standard deviation as used in my power analyses.

${ }^{10}$ The third screening criterion was whether the participant was using a personal computer. This criterion was necessary because the survey would not display properly on mobile devices.

${ }^{11}$ The professional survey service was paid $\$ 8$ per participant.
} 
the company (ANZ Technologies). Participants were then provided with financial statements supplemented with key company and industry ratios after which they were asked to provide their baseline assessments of their overall impression of ANZ as an investment (1-Unfavorable, 7Favorable), the extent to which they would invest their inheritance of $\$ 10,000$ in ANZ, and the likelihood of stock price decrease/increase (-7 High likelihood of a decline, +7 High likelihood of an increase). Afterwards, participants were presented with an IC report that contained the experimental manipulations followed by an opportunity to revise their baseline responses to the same impression, investment decision and investment risk questions as well as a fourth (new) question that prompted participants to provide their perceived risk of misstatement. The dependent variables for the study were the revised (later) assessments from the second stage and the risk of misstatement assessment.

Following the collection of the primary dependent variables, participants were asked manipulation check questions and a processing fluency question. Participants were then exclusively shown the specific ICW disclosed and asked to indicate their overall assessments of severity and likelihood of a future material error for all experimental conditions. For the control deficiency (disaggregate) conditions, once participants assessed the overall severity and likelihood of future material error, they were asked to indicate the severity and likelihood assessments for each control deficiency; recall that participants were also asked to indicate the combined severity and likelihood of future material error related to the combination of the CDs. The collection of both the combined and individual measures was performed to enable analyses of whether the sum of the parts is considered less or more than the whole (combination of CDs vs. MWs). Participants completed questions related to their perceptions of management, the 
internal control report, risk preferences, and their financial literacy. The experiment concluded with participants responding to several post-experimental questions and demographics questions.

\subsection{Statistical Analyses}

\subsubsection{Manipulation Checks}

Two manipulation check questions were asked to determine whether the manipulations are effective. The first manipulation check question (MCQ) asked participants the following: "What was (were) the type of internal control issue(s) indicated in management's report on internal control over financial reporting?” with the options: (i.) Three control deficiencies that are not material individually, but in aggregate, their combination could result in a material misstatement, (ii.) One material weakness that could result in a material misstatement.

1. What was (were) the type of internal control issue(s) indicated in management's report on internal control over financial reporting?

- Three control deficiencies that are not material individually, but in aggregate, their combination could result in a material misstatement

One material weakness that could result in a material misstatement

2. How was the part of the disclosure discussing the above internal control issue(s) formatted $/$ presented?

Identified with bullet point(s)

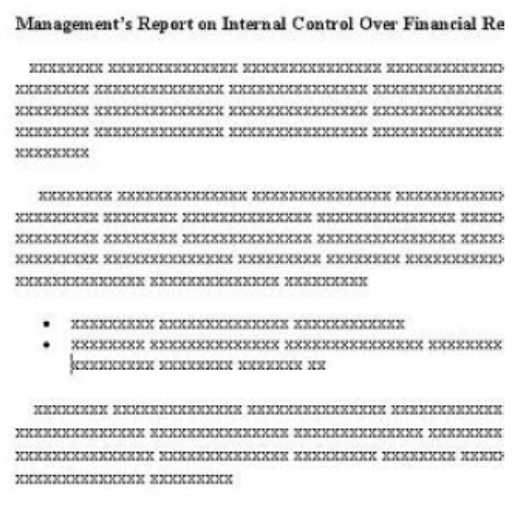

Not identified with bullet point(s)

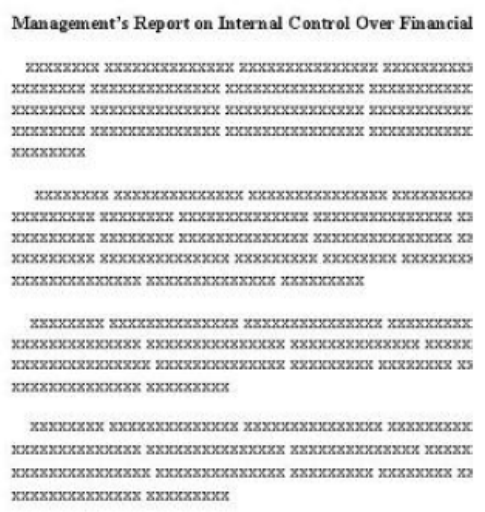

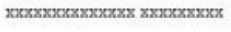

Figure 3. Manipulation Check Questions 
The second MCQ asked participants the following: "How was the part of the disclosure discussing the internal control issue(s) formatted/presented?” The participants were asked to select one of two images of page patterns as depicted in Figure 3: one that appeared to have bulleted lists between two paragraphs, and another that had three paragraphs with no bullets.

\subsubsection{Hypotheses Testing}

Hypothesis 1 posits that there will be a main effect of presentation salience of ICWs disclosed in IC reports on the perceived risk of misstatement. Hypothesis 2 predicts that there will be a main effect of presentation salience of ICWs disclosed in IC reports on investing judgments. Hypothesis testing for $\mathrm{H} 1$ and $\mathrm{H} 2$ is performed using a MANCOVA model followed by ANCOVA analyses on the misstatement risk variable and the likelihood of investing variables.

Hypothesis 1 is tested using the following ANCOVA model to examine the coefficient on the Salience variable. The means of risk of misstatement are also compared between the salient and stealth groups to validate the direction of the significance.

$$
\begin{aligned}
& \text { Risk of Misstatement }=\beta_{0}+\beta_{1} \text { Salience }+\beta_{2} \text { Disaggregation } \\
& +\beta_{3} \text { Salience } * \text { Disaggregation }+ \text { Covariates }
\end{aligned}
$$

Hypothesis 2 is also tested by examining the coefficient on the Salience variable in the model below. The means of each investing judgment variable are also compared between the salient and stealth conditions to validate the direction of the significance.

$$
\begin{aligned}
& \text { Revised Investing Judgments }=\beta_{0}+\beta_{1} \text { Salience }+\beta_{2} \text { Disaggregation } \\
& +\beta_{3} \text { Salience } * \text { Disaggregation }+\beta_{4} \text { Baseline Investing Judgments }+ \text { Covariates }
\end{aligned}
$$


Hypotheses 3 and 4 suggest that the effects of presentation salience and disaggregation on assessments of misstatement risk and investing decisions will be interactive, such that disaggregation will be viewed more favorable when it coincides with salient disclosure and more unfavorable when it coincides with stealth disclosure of ICWs. A MANCOVA model followed by separate ANCOVA models is used to test these hypotheses. This is followed up with posthoc comparison of means to determine if the effect of disaggregation and salience are interactive in the disaggregated conditions.

Hypothesis 3 is tested by examining the coefficient on the interaction between Salience and Disaggregation as shown in the risk of misstatement model that is used to test Hypothesis 1. A post-hoc comparison of means in the two disaggregated conditions will also be performed. Hypothesis 4 is tested by examining the coefficient on the interaction between Salience and Disaggregation as shown in the revised investing judgments model that is used to test Hypothesis 2. A post-hoc comparison of means of revised investing judgments in the two disaggregated conditions is also performed.

\subsection{Pilot Experiment}

A pilot experiment was conducted using 115 U.S. nonprofessional investors on M-Turk. The participants took an average of 18.3 minutes to complete the study. Participants had an average age of 56.32 years and average investing experience of 18.77 years. ${ }^{12}$ They had an average work experience of 25.31 years and had completed an average of 2.38 accounting courses and 1.97 finance courses. The descriptive statistics of the study are included in Table 4.3.

\footnotetext{
12 The relatively higher average age of participants likely resulted from screening out participants who were using mobile devices to complete the survey. The pre-screening criteria of only allowing participants using personal computers was necessary because the online survey would not display correctly on mobile devices.
} 


\begin{tabular}{|c|c|c|c|c|c|c|}
\hline & $\begin{array}{l}\text { Disaggregated } \\
\text { / Salient } \\
\text { Means (s.d. or } \\
\text { percent) } \\
\mathrm{n}=23 \\
\end{array}$ & $\begin{array}{l}\text { Disaggregated } \\
\text { / Stealth } \\
\text { Means (s.d. or } \\
\text { percent) } \\
\text { n = 22 }\end{array}$ & $\begin{array}{l}\text { Aggregated } \\
\text { / Salient } \\
\text { Means (s.d. } \\
\text { or percent) } \\
\mathrm{n}=21 \\
\end{array}$ & $\begin{array}{l}\text { Aggregated } \\
\text { / Stealth } \\
\text { Means (s.d. } \\
\text { or percent) } \\
\mathrm{n}=25 \\
\end{array}$ & $\begin{array}{l}\text { Restatement } \\
\text { / Control } \\
\text { Means (s.d. } \\
\text { or percent) } \\
\mathrm{n}=24 \\
\end{array}$ & $\begin{array}{c}\text { Overall } \\
\text { Sample } \\
\text { Means (s.d. } \\
\text { or percent) } \\
\mathrm{n}=115\end{array}$ \\
\hline Investor horizon & $\begin{array}{c}6.09 \\
(1.41) \\
\end{array}$ & $\begin{array}{c}6.68 \\
(2.03) \\
\end{array}$ & $\begin{array}{c}6.38 \\
(2.06) \\
\end{array}$ & $\begin{array}{c}5.44 \\
(2.69) \\
\end{array}$ & $\begin{array}{c}6.83 \\
(1.99) \\
\end{array}$ & $\begin{array}{c}6.27 \\
(2.12) \\
\end{array}$ \\
\hline $\begin{array}{l}\text { Reliance on } \\
\text { financial advisor }\end{array}$ & $\begin{array}{c}2.87 \\
(1.71) \\
\end{array}$ & $\begin{array}{c}2.00 \\
(1.54) \\
\end{array}$ & $\begin{array}{c}2.38 \\
(1.63) \\
\end{array}$ & $\begin{array}{c}2.48 \\
(1.78) \\
\end{array}$ & $\begin{array}{c}3.00 \\
(2.38) \\
\end{array}$ & $\begin{array}{c}2.56 \\
(1.85) \\
\end{array}$ \\
\hline $\begin{array}{l}\text { Investing } \\
\text { experience (years) }\end{array}$ & $\begin{array}{r}3.83 \\
(4.49) \\
\end{array}$ & $\begin{array}{r}6.36 \\
(4.77) \\
\end{array}$ & $\begin{array}{r}8.90 \\
(7.27) \\
\end{array}$ & $\begin{array}{r}8.56 \\
(6.76) \\
\end{array}$ & $\begin{array}{c}5.46 \\
(5.48) \\
\end{array}$ & $\begin{array}{r}6.61 \\
(6.06) \\
\end{array}$ \\
\hline $\begin{array}{l}\text { Gender } \\
\text { Male } \\
\text { Female }\end{array}$ & $\begin{array}{c}20(87 \%) \\
3(13 \%) \\
\end{array}$ & $\begin{array}{c}15(68 \%) \\
7(32 \%)\end{array}$ & $\begin{array}{c}20(95 \%) \\
1(5 \%) \\
\end{array}$ & $\begin{array}{c}17(68 \%) \\
8(32 \%)\end{array}$ & $\begin{array}{l}20(83 \%) \\
4(17 \%)\end{array}$ & $\begin{array}{l}92(80 \%) \\
23(20 \%)\end{array}$ \\
\hline Age & $\begin{array}{l}27.35 \\
(9.15) \\
\end{array}$ & $\begin{array}{l}29.36 \\
(6.17) \\
\end{array}$ & $\begin{array}{c}34.76 \\
(13.51) \\
\end{array}$ & $\begin{array}{c}34.80 \\
(10.61) \\
\end{array}$ & $\begin{array}{l}30.83 \\
(9.43) \\
\end{array}$ & $\begin{array}{c}31.43 \\
(10.28) \\
\end{array}$ \\
\hline College credits & $\begin{array}{c}99.87 \\
(51.77) \\
\end{array}$ & $\begin{array}{c}155.73 \\
(194.94) \\
\end{array}$ & $\begin{array}{r}89.52 \\
(70.42) \\
\end{array}$ & $\begin{array}{l}110.88 \\
(64.00) \\
\end{array}$ & $\begin{array}{l}124.17 \\
(46.83) \\
\end{array}$ & $\begin{array}{c}116.13 \\
(100.99) \\
\end{array}$ \\
\hline Business degree & $\begin{array}{c}8.00 \\
(35 \%)\end{array}$ & $\begin{array}{c}7.00 \\
(32 \%) \\
\end{array}$ & $\begin{array}{c}4.00 \\
(19 \%)\end{array}$ & $\begin{array}{c}6.00 \\
(24 \%)\end{array}$ & $\begin{array}{c}6.00 \\
(25 \%)\end{array}$ & $\begin{array}{l}31.00 \\
(27 \%) \\
\end{array}$ \\
\hline $\begin{array}{l}\text { Accounting } \\
\text { courses }\end{array}$ & $\begin{array}{c}2.65 \\
(3.72) \\
\end{array}$ & $\begin{array}{c}3.05 \\
(3.95) \\
\end{array}$ & $\begin{array}{c}2.67 \\
(4.78) \\
\end{array}$ & $\begin{array}{c}1.16 \\
(1.43) \\
\end{array}$ & $\begin{array}{c}2.33 \\
(3.00) \\
\end{array}$ & $\begin{array}{c}2.34 \\
(3.50) \\
\end{array}$ \\
\hline Business courses & $\begin{array}{c}4.35 \\
(5.51) \\
\end{array}$ & $\begin{array}{c}6.32 \\
(8.62) \\
\end{array}$ & $\begin{array}{c}3.05 \\
(3.85) \\
\end{array}$ & $\begin{array}{c}4.56 \\
(6.36) \\
\end{array}$ & $\begin{array}{c}5.17 \\
(6.06) \\
\end{array}$ & $\begin{array}{c}4.70 \\
(6.26) \\
\end{array}$ \\
\hline $\begin{array}{l}\text { Duration } \\
\text { (minutes) }\end{array}$ & $\begin{array}{c}14.22 \\
(12.00) \\
\end{array}$ & $\begin{array}{l}13.68 \\
(6.27 \\
\end{array}$ & $\begin{array}{l}14.86 \\
(6.69) \\
\end{array}$ & $\begin{array}{l}12.72 \\
(5.20) \\
\end{array}$ & $\begin{array}{r}9.04 \\
(7.90) \\
\end{array}$ & $\begin{array}{l}12.83 \\
(8.09) \\
\end{array}$ \\
\hline $\begin{array}{l}\text { Risk of stock price } \\
\text { decline }\end{array}$ & $\begin{array}{c}4.48 \\
(1.59) \\
\end{array}$ & $\begin{array}{c}5.36 \\
(1.47) \\
\end{array}$ & $\begin{array}{c}5.24 \\
(1.67) \\
\end{array}$ & $\begin{array}{c}5.28 \\
(1.93) \\
\end{array}$ & $\begin{array}{c}4.92 \\
(1.53) \\
\end{array}$ & \\
\hline $\begin{array}{l}\text { Likelihood of } \\
\text { investing }\end{array}$ & $\begin{array}{c}50.87 \\
(20.65) \\
\end{array}$ & $\begin{array}{c}46.36 \\
(19.89) \\
\end{array}$ & $\begin{array}{c}50.95 \\
(20.47) \\
\end{array}$ & $\begin{array}{l}41.20 \\
(5.20) \\
\end{array}$ & $\begin{array}{c}49.17 \\
(18.86) \\
\end{array}$ & \\
\hline \multicolumn{7}{|c|}{$\begin{array}{l}\text { Investor horizon (short term investing horizon }-1 \text {, long term investing horizon - } 9 \text { ) } \\
\text { Reliance on financial advisor (1-I manage all my investments on my own , 7-I let my financial advisor/planner manage my } \\
\text { investments) } \\
\text { Risk of stock price decline - the risk of a moderate (1-10\%) stock price decline in the next year (1-very low, 9- very high) } \\
\text { Likelihood of investing - likelihood of investing on an } 11 \text { point scale (No chance }=0 \text {, Certain to invest }=100)\end{array}$} \\
\hline
\end{tabular}

Thirty-five out of 115 participants failed all manipulation check questions and only 18 participants were able to answer all the manipulation check questions correctly. One explanation for such a high manipulation failure rate in the pilot study is that participants were presented with 
a remediation report immediately before the questions were asked. ${ }^{13}$ Therefore, participants may have focused on the remediation information when responding to the questions.

The results from the pilot study can be summarized as follows. There is a marginally significant main effect of salience on the likelihood of investing but not on the assessments of investment risk. Investors were less likely to invest when the ICW disclosure salience was low (in-text) than when it was high (bullets), providing preliminary support for H2. There was a main effect of disaggregation on investment risk and likelihood of investing such that disaggregation lead to underweighting of ICWs. There was also a significant interaction between financial literacy and salience and disaggregation. This suggests that additional investigation of financial literacy and inclusion of the variable as a covariate is warranted in the study.

\subsubsection{Lessons Learned from the Pilot Study}

The pilot study helped identify several problems with the instrument that has since been updated in the dissertation.

1. The pilot instrument included analyst forecasts information and presented the case as a restatement setting. The analyst forecast information was removed in the dissertation to reduce noise in the measured dependent variables. The restatement setting was also removed in the dissertation to avoid problems of operational validity.

2. High manipulation check failures are likely to have been caused by poor placement and wording in the MCQs. The questions were improved to address the ambiguity and were placed immediately after the manipulation in the current version of the instrument.

3. It was not clear whether participants were responding to the financial performance or the disclosure of the ICWs. This was addressed by changing the instrument to a pre-post design, where participants' assessments of the company's financials are

\footnotetext{
13 The remediation of ICWs disclosure that was presented after the manipulations was included in the pilot for exploratory purposes and is not included in the dissertation.
} 
captured in the first stage and their assessments to ICWs are captured in the second stage.

4. The restatement setting may have impacted the results such that participants were negatively primed. In a restatement setting, investors are likely to consider ICWs as an explanation for the restatement, and thus should penalize the company less when they are aware of the presence of ICWs. Therefore the pilot results are consistent with the idea that salient ICWs would lead to positive responses and result in investors being more likely to invest. Removing the restatement setting is expected to change the pilot results to the predicted direction. 


\section{RESULTS}

\subsection{Manipulation Checks, Attention Checks, and Final Sample Size}

\subsubsection{Attention Checks}

Attention checks were implemented with the help of the panel service to identify those that were speeding through the experiment and not attending to the task. The question "please select ' 6 ' for this question”' was included in the post-experimental questionnaire to help identify participants who were not attending to the task. Thirty-eight participants were identified as failing this attention check and were removed by the survey company. Eleven participants were identified as speeders and were also excluded by the survey company. After exclusion of the speeders and attention check failures, the data collection service provided 361 observations.

\subsubsection{Manipulation Checks and Final Sample Size}

Out of 361 observations, 109 participants failed the manipulation check question regarding the type of internal control issue (CDs or MWs) and 146 participants failed the manipulation check question regarding the type of presentation format that was used (bullets or in-text). ${ }^{14}$ Despite the relatively high manipulation failures, I was able to collect enough observations to run my statistical analyses using data of participants who passed both the manipulation check questions. The final sample size used in all hypotheses included 164 observations of participants who passed all manipulations check questions.

\footnotetext{
${ }^{14}$ One explanation for the high rate of failure in the manipulation check questions is that the survey company advertised the experiment as a "short 9 minute survey". However, the mean duration of the study as indicated in the descriptive statistics is around 18 minutes.
} 
Eighty-one of the 361 observations provided by the panel service had incomplete data due to the survey company choosing to terminate the sessions for participants who failed the specified manipulation check questions. ${ }^{15}$ Therefore, sensitivity tests that included the manipulation failures and required use of covariates were limited to 280 observations. Table 5.1 compares the descriptive statistics for participants who failed the manipulation check questions with those who passed. Participants who failed the manipulation check questions on average were less educated $(p=.056)$ and had taken a lower number of finance courses $(p<.072)$. Lower means of financial literacy was also associated with participants who failed manipulation check questions ( $p=.002$ ). On the other hand, participants who passed the manipulation check were more familiar with $10 \mathrm{~K}$ reports $(p=.04)$ and on average read MD\&A and Auditor's reports more frequently (based on 1-tailed tests driven by directional expectations, $p<.10$ ). There was also a significant difference in IC knowledge between the participants who failed the manipulation check questions and those who passed. Those who failed the manipulation on average indicated lower understanding of IC ( $p=.099)$ and thought they were less influenced by IC reports $(p=.006)$.

As expected, baseline investing judgment responses were not significantly different between participants who passed and failed manipulation checks. However, means in all the revision investing variables were significantly higher for those who failed manipulation checks $(p<.10)$ indicating that they did not process the IC disclosure. The risk of misstatement means were also significantly lower (1-tailed, $p<.10$ ) for those who failed manipulation checks

\footnotetext{
${ }^{15}$ An agreement for non-payment of manipulation failure observations led to an error on the survey company's programming logic that terminated 81 manipulation failure observations before they responded to the post experimental questionnaire. This issue was corrected half way into the data collection leaving 116 manipulation failure observations with completed responses.
} 


\begin{tabular}{|c|c|c|c|c|c|}
\hline Manipulation checks & Passed & $\mathrm{n}=164$ & Failed & $n=116$ & $p$-value \\
\hline & Mean & Std. dev & Mean & Std. dev & (2-tailed sig.) \\
\hline Duration & 1097.98 & 2104.68 & 955.76 & 760.80 & 0.487 \\
\hline Age & 56.32 & 14.65 & 57.29 & 14.28 & 0.579 \\
\hline Investing experience & 18.77 & 15.37 & 33.57 & 185.75 & 0.311 \\
\hline Work experience & 25.31 & 14.83 & 25.09 & 15.43 & 0.902 \\
\hline Reliance on financial advisors & 3.41 & 2.16 & 3.58 & 2.09 & 0.513 \\
\hline Education (1-none,7-doctorate) & 4.77 & 1.30 & 4.47 & 1.35 & 0.056 \\
\hline Business degree ( $1=$ yes, $0=$ no) & 0.31 & 0.46 & 0.29 & 0.46 & 0.750 \\
\hline Accounting courses & 2.38 & 3.87 & 2.01 & 2.72 & 0.369 \\
\hline Finance courses & 1.97 & 2.89 & 1.42 & 1.82 & 0.072 \\
\hline Financial literacy & 8.41 & 1.96 & 7.62 & 2.26 & 0.002 \\
\hline $\begin{array}{l}\text { Risk preference (0-risk averse, 3- } \\
\text { risk seeking) }\end{array}$ & 0.66 & 0.94 & 0.97 & 1.05 & 0.011 \\
\hline Processing fluency & 4.55 & 1.38 & 4.47 & 1.24 & 0.605 \\
\hline Severity of overall ICW reported & 4.61 & 1.29 & 4.58 & 1.24 & 0.835 \\
\hline $\begin{array}{l}\text { Likelihood of material error of } \\
\text { overall ICW reported }\end{array}$ & 61.16 & 19.36 & 58.45 & 18.01 & 0.236 \\
\hline Familiarity with $10 \mathrm{k}$ reports & 4.16 & 1.54 & 3.78 & 1.43 & 0.040 \\
\hline IC understanding check & 2.85 & 1.42 & 2.97 & 1.29 & 0.468 \\
\hline Self-assessed IC understanding & 3.88 & 1.48 & 3.59 & 1.39 & 0.099 \\
\hline $\begin{array}{l}\text { ICFR influences my investing } \\
\text { decision }\end{array}$ & 5.08 & 1.18 & 4.67 & 1.27 & 0.006 \\
\hline MD\&A reading frequency & 2.37 & 0.87 & 2.21 & 0.82 & 0.125 \\
\hline Audit report reading frequency & 2.21 & 0.91 & 2.36 & 0.94 & 0.183 \\
\hline Footnotes reading frequency & 2.25 & 0.88 & 2.36 & 0.90 & 0.299 \\
\hline Reliability of IC report & 3.70 & 1.38 & 3.74 & 1.39 & 0.811 \\
\hline Management competence & 4.08 & 1.47 & 3.97 & 1.39 & 0.547 \\
\hline Management trustworthiness & 3.91 & 1.44 & 3.89 & 1.35 & 0.876 \\
\hline Risk of misstatement & 6.04 & 1.95 & 5.66 & 1.97 & 0.118 \\
\hline Baseline impression of investment & 4.51 & 1.15 & 4.36 & 1.10 & 0.275 \\
\hline Baseline invested amount & 2314.47 & 2518.00 & 2521.59 & 2582.87 & 0.503 \\
\hline $\begin{array}{l}\text { Baseline likelihood of price } \\
\text { decline/increase }\end{array}$ & 9.84 & 2.08 & 10.06 & 2.02 & 0.381 \\
\hline Revised impression of investment & 3.26 & 1.30 & 3.65 & 1.22 & 0.013 \\
\hline Revised invested amount & 1266.42 & 2091.27 & 1774.57 & 2328.14 & 0.057 \\
\hline $\begin{array}{l}\text { Revised likelihood of price } \\
\text { decline/increase }\end{array}$ & 7.38 & 2.77 & 8.29 & 2.60 & 0.006 \\
\hline
\end{tabular}


indicating that they perceived the investment as lower risk. Participants who failed manipulation checks may not have read, understood, or cared to incorporate the ICW disclosure, providing more rationale to exclude these participants in hypothesis testing.

Processing fluency was also measured after the manipulations by asking participants the following question: "The specific section discussing the internal control issue(s) disclosed was clearly presented/easy to understand" (1-Strongly disagree, 7- Strongly agree). Participants who briefly glanced at the IC report should be able to indicate higher scores than those who failed to attend to the task. To test this notion, I ran separate ANOVA models that test the differences in the mean of processing fluency for the group of participants who failed the manipulation check questions and those who passed the manipulation check. As depicted in Figure 4, participants who passed the manipulation check questions indicated higher processing fluency scores in the salient conditions than in the stealth conditions (significant ANOVA and main effect of salience, $\mathrm{F}=16.419 p<.001$ ). Conversely, participants who failed manipulation check questions indicated no difference in their processing fluency responses and even higher means in the disaggregated condition for stealth conditions rather than the salient condition (insignificant ANOVA and salience is not significant, $\mathrm{F}=.939, p=.334$ ). It is apparent that those who failed the manipulation check question were clearly not paying attention or did not spend ample time reviewing the IC report.

In addition to manipulation and attention check questions, I followed Rose et al. (2010) and asked participants an understanding check question: "How does the presence of internal control weaknesses affect a company's financial reporting system?” (1-Negatively, 7Positively). Similar to Rose et al. (2010), investors' appeared to have an understanding of the 
negative effect of ICWs, indicated by a mean assessment of 2.85 which is less than the mid-point of 4.00 (t-value -10.341, p-value $<.000$ ).

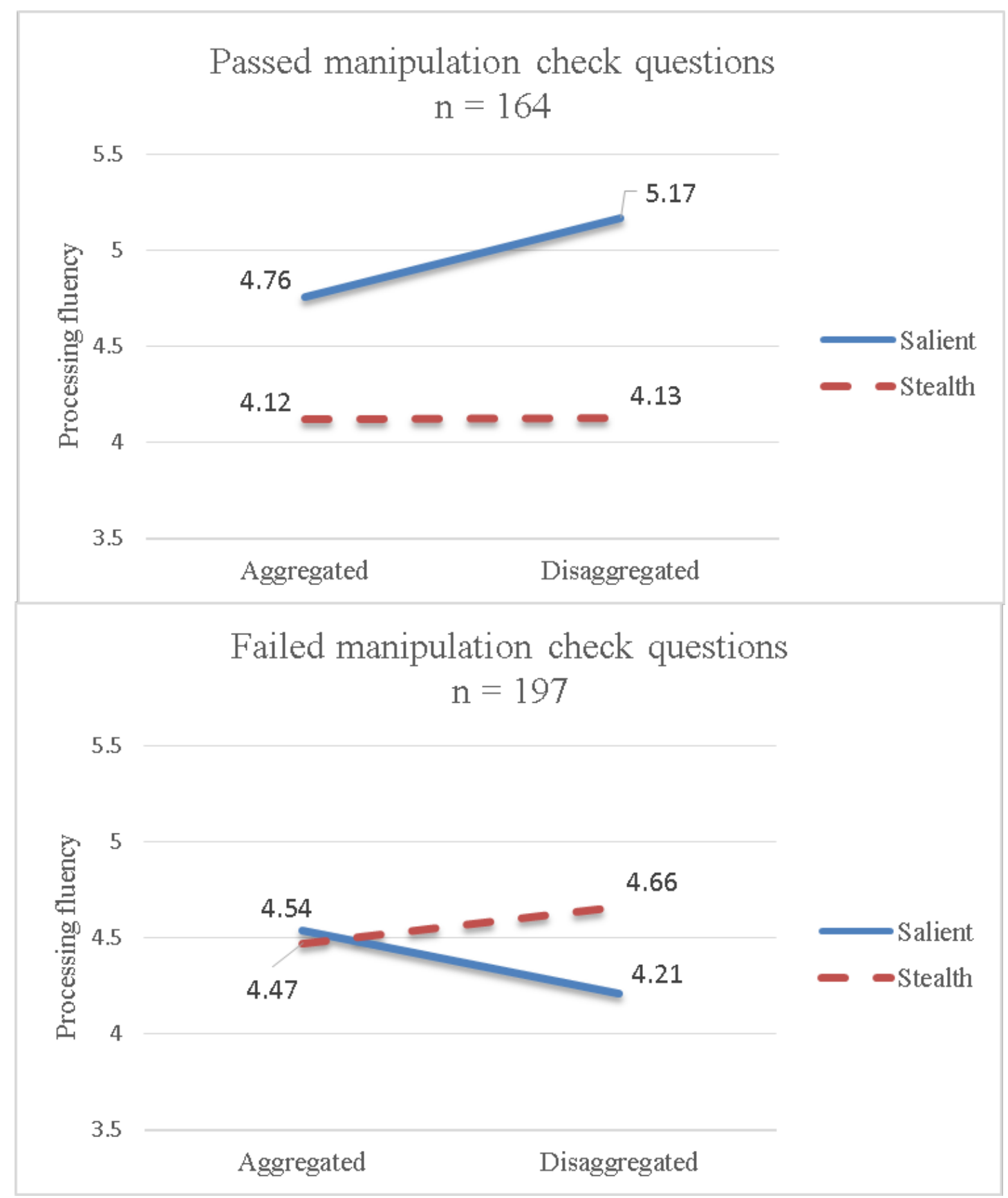

Figure 4. Means of Processing Fluency by Manipulation Check (Fail/Pass) 


\subsection{Demographic Statistics}

Fifty-seven (34.8\%) of the participants were female and 107 (65.2\%) of the participants were male. Participants had an average age of 56.32 years and average work experience of 25.31 years. ${ }^{16}$ They had an average investing experience of 18.77 years and on average indicated 3.41 as the extent to which they would rely on financial advisor/ broker/ planner for investments ( 1- I manage all my investments on my own, 7-I let my financial advisor/planner handle all my investments). The participants' trading frequency was 1.34, a coded figure that refers to an average that is greater than 10 trades per year but less than 100 trades per year (1- Less than 10 trades per year, 2- 10 to 100 trades per year, 3- 100 to 1000 trades per year, 4- Over 1,000 trades per year). In terms of education level, the average participant had more coursework than an associate’s degree, but less than a bachelor's degree. Sixty-two participants (37.8\%) had graduated with a bachelor's degree and 43 participants (26.2\%) had graduated with a master's degree. Fifty-one participants (31.1\%) indicated that they have a business degree. Participants had completed an average of 2.38 accounting courses and 1.97 finance courses. Participants had an average score of 8.41 out of 11 on a financial literacy scale taken from Van Rooij et al.(2011), indicating that they had at least moderate financial literacy as nonprofessional investors. The time to complete the study took an average of 18.3 minutes. The demographics and additional descriptive statistics of the study are included in Table 5.2. A description of the variables used is tabulated on Table 4.2.

\footnotetext{
${ }^{16}$ The relatively higher average age of participants likely resulted from screening out participants who were using mobile devices to complete the survey. The pre-screening criteria of only allowing participants using personal computers was necessary because the online survey would not display correctly on mobile devices.
} 


\begin{tabular}{|c|c|c|c|c|c|c|}
\hline Variables & $\begin{array}{l}\text { Disaggregated } \\
\text { / Salient } \\
(\mathrm{n}=42) \\
\end{array}$ & $\begin{array}{l}\text { Disaggregated } \\
\text { / Stealth } \\
(\mathrm{n}=39) \\
\end{array}$ & $\begin{array}{l}\text { Aggregated } \\
\text { / Salient } \\
(\mathrm{n}=41) \\
\end{array}$ & $\begin{array}{l}\text { Aggregated } \\
\text { / Stealth } \\
(\mathrm{n}=42) \\
\end{array}$ & $\begin{array}{l}\text { Total } \\
(n=164)\end{array}$ & \\
\hline & $\begin{array}{l}\text { Mean (s.d. or } \\
\text { percent) }\end{array}$ & $\begin{array}{l}\text { Mean (s.d. or } \\
\text { percent) }\end{array}$ & $\begin{array}{l}\text { Mean (s.d. } \\
\text { or percent) }\end{array}$ & $\begin{array}{l}\text { Mean (s.d. } \\
\text { or percent) }\end{array}$ & $\begin{array}{l}\text { Mean (s.d. } \\
\text { or percent) }\end{array}$ & \begin{tabular}{|l|}
$p-$ \\
values \\
\end{tabular} \\
\hline $\begin{array}{c}\text { Gender } \\
\text { Female } \\
\text { Male } \\
\end{array}$ & $\begin{array}{l}16(38 \%) \\
26(62 \%) \\
\end{array}$ & $\begin{array}{l}12(31 \%) \\
27(69 \%) \\
\end{array}$ & $\begin{array}{l}15(27 \%) \\
26(63 \%) \\
\end{array}$ & $\begin{array}{l}14(23 \%) \\
28(67 \%) \\
\end{array}$ & $\begin{array}{c}57(35 \%) \\
107(65 \%)\end{array}$ & 0.904 \\
\hline Age & $\begin{array}{c}53.33 \\
(14.906)\end{array}$ & $\begin{array}{c}57.21 \\
(14.893)\end{array}$ & $\begin{array}{c}55.78 \\
(14.015)\end{array}$ & $\begin{array}{c}59.00 \\
(14.723)\end{array}$ & $\begin{array}{c}56.32 \\
(14.654)\end{array}$ & 0.343 \\
\hline $\begin{array}{l}\text { Professional work } \\
\text { experience }\end{array}$ & $\begin{array}{c}25.50 \\
(14.576)\end{array}$ & $\begin{array}{c}25.79 \\
(14.977)\end{array}$ & $\begin{array}{c}23.17 \\
(14.634)\end{array}$ & $\begin{array}{c}26.76 \\
(15.424) \\
\end{array}$ & $\begin{array}{c}25.31 \\
(14.828)\end{array}$ & 0.732 \\
\hline Investing experience & $\begin{array}{c}16.45 \\
(11.89) \\
\end{array}$ & $\begin{array}{c}19.72 \\
(19.216)\end{array}$ & $\begin{array}{c}19.95 \\
(15.643) \\
\end{array}$ & $\begin{array}{c}19.07 \\
(14.438) \\
\end{array}$ & $\begin{array}{c}18.77 \\
(15.366) \\
\end{array}$ & 0.718 \\
\hline $\begin{array}{l}\text { Reliance on } \\
\text { financial advisor }\end{array}$ & $\begin{array}{c}3.71 \\
(2.028)\end{array}$ & $\begin{array}{c}3.03 \\
(2.146)\end{array}$ & $\begin{array}{c}3.17 \\
(2.024)\end{array}$ & $\begin{array}{c}3.69 \\
(2.394)\end{array}$ & $\begin{array}{c}3.41 \\
(2.156)\end{array}$ & 0.351 \\
\hline Trading frequency & $\begin{array}{l}1.45 \\
(.55)\end{array}$ & $\begin{array}{l}1.23 \\
(.485)\end{array}$ & $\begin{array}{c}1.41 \\
(.547)\end{array}$ & $\begin{array}{c}1.26 \\
(.544)\end{array}$ & $\begin{array}{c}1.34 \\
(.536)\end{array}$ & 0.161 \\
\hline Education rank & $\begin{array}{c}4.57 \\
(1.364)\end{array}$ & $\begin{array}{c}5.00 \\
(1.277)\end{array}$ & $\begin{array}{c}4.63 \\
(1.157)\end{array}$ & $\begin{array}{c}4.90 \\
(1.394)\end{array}$ & $\begin{array}{c}4.77 \\
(1.303)\end{array}$ & 0.381 \\
\hline Business degree & $13(31 \%)$ & $14(36 \%)$ & $12(29 \%)$ & $12(29 \%)$ & $51(31 \%)$ & 0.897 \\
\hline Accounting courses & $\begin{array}{c}2.12 \\
(3.329) \\
\end{array}$ & $\begin{array}{c}3.08 \\
(4.521) \\
\end{array}$ & $\begin{array}{c}1.76 \\
(2.606)\end{array}$ & $\begin{array}{c}2.62 \\
(4.685)\end{array}$ & $\begin{array}{c}2.38 \\
(3.871) \\
\end{array}$ & 0.447 \\
\hline Finance courses & $\begin{array}{c}1.62 \\
(2.083)\end{array}$ & $\begin{array}{c}2.69 \\
(4.317)\end{array}$ & $\begin{array}{c}1.80 \\
(2.136)\end{array}$ & $\begin{array}{c}1.81 \\
(2.521)\end{array}$ & $\begin{array}{c}1.97 \\
(2.885)\end{array}$ & 0.346 \\
\hline Financial literacy & $\begin{array}{c}8.21 \\
(2.09)\end{array}$ & $\begin{array}{c}8.46 \\
(2.024)\end{array}$ & $\begin{array}{c}8.34 \\
(1.983)\end{array}$ & $\begin{array}{c}8.62 \\
(1.766)\end{array}$ & $\begin{array}{c}8.41 \\
(1.956)\end{array}$ & 0.810 \\
\hline Risk preference & $\begin{array}{c}0.93 \\
(1.113)\end{array}$ & $\begin{array}{c}0.54 \\
(.822)\end{array}$ & $\begin{array}{c}0.49 \\
(.952)\end{array}$ & $\begin{array}{c}0.67 \\
(.816)\end{array}$ & $\begin{array}{c}0.66 \\
(.943)\end{array}$ & 0.143 \\
\hline Investment horizon & $\begin{array}{c}7.36 \\
(1.206)\end{array}$ & $\begin{array}{c}7.21 \\
(1.852)\end{array}$ & $\begin{array}{c}7.15 \\
(1.636)\end{array}$ & $\begin{array}{c}7.55 \\
(1.533)\end{array}$ & $\begin{array}{c}7.32 \\
(1.562)\end{array}$ & 0.656 \\
\hline $\begin{array}{l}\text { Familiarity with } \\
\text { 10K reports }\end{array}$ & $\begin{array}{c}4.29 \\
(1.293) \\
\end{array}$ & $\begin{array}{c}4.77 \\
(1.307)\end{array}$ & $\begin{array}{c}4.05 \\
(1.731) \\
\end{array}$ & $\begin{array}{c}3.57 \\
(1.595) \\
\end{array}$ & $\begin{array}{c}4.16 \\
(1.543) \\
\end{array}$ & 0.005 \\
\hline Investor inactive & $\begin{array}{c}4.17 \\
(4.752)\end{array}$ & $\begin{array}{c}3.23 \\
(3.602)\end{array}$ & $\begin{array}{c}3.39 \\
(2.999)\end{array}$ & $\begin{array}{c}3.69 \\
(5.825)\end{array}$ & $\begin{array}{c}3.63 \\
(4.424)\end{array}$ & 0.789 \\
\hline $\begin{array}{l}\text { MDNA reading } \\
\text { frequency }\end{array}$ & $\begin{array}{c}2.48 \\
(.833)\end{array}$ & $\begin{array}{c}2.38 \\
(.847)\end{array}$ & $\begin{array}{c}2.49 \\
(.898)\end{array}$ & $\begin{array}{c}2.12 \\
(.889)\end{array}$ & $\begin{array}{c}2.37 \\
(.872)\end{array}$ & 0.183 \\
\hline $\begin{array}{l}\text { Audit Report } \\
\text { reading frequency }\end{array}$ & $\begin{array}{c}2.38 \\
(.936) \\
\end{array}$ & $\begin{array}{c}2.26 \\
(.966) \\
\end{array}$ & $\begin{array}{c}2.27 \\
(.867) \\
\end{array}$ & $\begin{array}{c}1.95 \\
(.825) \\
\end{array}$ & $\begin{array}{c}2.21 \\
(.905) \\
\end{array}$ & 0.159 \\
\hline $\begin{array}{l}\text { Footnotes reading } \\
\text { frequency }\end{array}$ & $\begin{array}{c}2.40 \\
(.767)\end{array}$ & $\begin{array}{c}2.28 \\
(.999)\end{array}$ & $\begin{array}{c}2.27 \\
(.923)\end{array}$ & $\begin{array}{c}2.05 \\
(.825)\end{array}$ & $\begin{array}{c}2.25 \\
(.882)\end{array}$ & 0.313 \\
\hline $\begin{array}{l}\text { Self-assessed IC } \\
\text { understanding }\end{array}$ & $\begin{array}{c}3.90 \\
(1.284)\end{array}$ & $\begin{array}{c}4.28 \\
(1.255)\end{array}$ & $\begin{array}{c}4.00 \\
(1.581) \\
\end{array}$ & $\begin{array}{c}3.38 \\
(1.652) \\
\end{array}$ & $\begin{array}{c}3.88 \\
(1.48) \\
\end{array}$ & 0.046 \\
\hline $\begin{array}{l}\text { ICFR influences my } \\
\text { investing decision }\end{array}$ & $\begin{array}{c}4.95 \\
(.987)\end{array}$ & $\begin{array}{c}5.36 \\
(1.203) \\
\end{array}$ & $\begin{array}{c}5.00 \\
(1.118) \\
\end{array}$ & $\begin{array}{c}5.02 \\
(1.388) \\
\end{array}$ & $\begin{array}{c}5.08 \\
(1.183) \\
\end{array}$ & 0.404 \\
\hline $\begin{array}{l}\text { CDs vs MW } \\
\text { severity rating }\end{array}$ & $\begin{array}{c}4.62 \\
(1.188)\end{array}$ & $\begin{array}{c}4.82 \\
(1.233)\end{array}$ & $\begin{array}{c}4.63 \\
(1.178) \\
\end{array}$ & $\begin{array}{c}4.50 \\
(1.194) \\
\end{array}$ & $\begin{array}{c}4.64 \\
(1.192) \\
\end{array}$ & 0.689 \\
\hline
\end{tabular}




\subsection{Descriptive Statistics of Dependent Variables and other Related Variables}

Table 5.3 shows the means and standard deviation for the dependent variables as well as other covariates. The descriptive statistics on these variables is tabulated for the four experimental conditions along with the overall sample. The mean (s.d.) risk of misstatement for the overall sample is 6.04 (1.95). The aggregated/stealth condition had the highest mean risk of misstatement (6.50) and the aggregated/salient condition had the lowest mean risk of misstatement (5.63). The revised investment judgment dependent variables reflected means that were lower than the midpoint as expected with the scenario of material weakness disclosures (bad news). The means for the salient conditions were higher for revised impression of investment and revised investment amount. The relatively low mean of baseline invested amount of 2,314.47 on a continuous range of possible entries of 0 -to-10,000 indicates that the investment may have not been attractive enough to lead to investing the entire inheritance of $\$ 10,000$. The mean revised investment amount was $1,266.42$. The overall mean for revised likelihood of price decrease/ increase was 7.38, which was also below the midpoint of "8-No change."

Participants’ assessments of processing fluency were higher on average for the salient conditions than the stealth conditions. The mean severity of overall ICW reported was 4.61 on a seven-point Likert scale (1-Very low severity, 7- Very high severity). Assessments of likelihood of material error of overall ICW reported had a mean of 61.1 on a 101 point scale. Participants' average assessment of the reliability of the IC report was 3.70 on a seven-point Likert scale. The mean management competence and trustworthiness were 4.08 and 3.91 respectively on sevenpoint Likert scales. The IC understanding check variable, collected by asking how the presence of internal control weaknesses affects a company's financial reporting system, had a mean of 
2.85 on a seven-point Likert scale (1-Negative, 7-Positive) indicating that participants understood the negative effect of internal control weaknesses on financial reporting. A description of the variables used is tabulated on Table 4.2.

\subsection{Correlations among Dependent Variables and other Related Variables}

The Spearman correlation coefficients between the dependent variables and other covariates are listed in Table 5.4. There is a significant negative correlation between the risk of misstatement and revised investment judgments, reliability, management competence and trust measures. Risk of misstatement is positively correlated with severity and likelihood measures for the ICWs. The moderately strong correlation between the dependent variables indicated that the use of MANCOVA would be necessary. A description of the variables used is tabulated on Table 4.2.

Further examination of the correlation report tabulated in Table 5.4 and additional correlation analyses (not tabulated) between dependent variables and participants' demographics and other possible covariates was necessary to select covariates for the models used in testing the hypotheses. The inclusion criteria for covariates were four fold. First, the potential covariate must be a continuous variable for inclusion in an ANCOVA model. Second, there had to be a significant correlation between the dependent variable and any potential covariates. Third, the correlation between the independent variables and covariates must be low. Four, the correlation between covariates and other covariates must be low to avoid a problem of multi-collinearity. The coefficient threshold value of .20 is used to define low correlation between independent variables and covariates or among covariates (Evans 1996). For instance, baseline invested amount and baseline impression of investment variables are highly correlated (r=.617) and 
therefore preclude the use of revised invested amount and revised impression of investment as dependent variables in the same MANCOVA model.

\begin{tabular}{|c|c|c|c|c|c|c|c|}
\hline \multirow[t]{2}{*}{ Variables } & \multirow{2}{*}{$\begin{array}{l}\begin{array}{l}\text { Disaggrega- } \\
\text { ted / Salient } \\
(\mathrm{n}=42)\end{array} \\
\text { Mean (s.d. } \\
\text { or percent) }\end{array}$} & \multirow{2}{*}{$\begin{array}{l}\begin{array}{l}\text { Disaggrega- } \\
\text { ted / Stealth } \\
(\mathrm{n}=39)\end{array} \\
\begin{array}{c}\text { Mean (s.d. } \\
\text { or percent) }\end{array}\end{array}$} & \multirow{2}{*}{$\begin{array}{c}\begin{array}{c}\text { Aggregated } \\
\text { / Salient } \\
(\mathrm{n}=41)\end{array} \\
\text { Mean (s.d. } \\
\text { or percent) }\end{array}$} & \multirow{2}{*}{$\begin{array}{c}\text { Aggregated } \\
\text { / Stealth } \\
(\mathrm{n}=42)\end{array}$} & \multicolumn{3}{|c|}{$\begin{array}{l}\text { Overall Sample Descriptive } \\
\text { Statistics }(n=164)\end{array}$} \\
\hline & & & & & $\begin{array}{l}\text { Mean (s.d. } \\
\text { or percent) }\end{array}$ & Min & Max \\
\hline $\begin{array}{l}\text { Risk of } \\
\text { misstatement }\end{array}$ & $\begin{array}{c}5.93 \\
1.702 \\
\end{array}$ & $\begin{array}{c}6.08 \\
2.057\end{array}$ & $\begin{array}{c}5.63 \\
2.211\end{array}$ & $\begin{array}{c}6.50 \\
1.757\end{array}$ & $\begin{array}{c}6.04 \\
1.947 \\
\end{array}$ & 0 & 10 \\
\hline $\begin{array}{l}\text { Revised impression } \\
\text { of investment }\end{array}$ & $\begin{array}{c}3.60 \\
(1.326) \\
\end{array}$ & $\begin{array}{c}2.90 \\
(1.021) \\
\end{array}$ & $\begin{array}{c}3.49 \\
(1.381) \\
\end{array}$ & $\begin{array}{c}3.05 \\
(1.343) \\
\end{array}$ & $\begin{array}{c}3.26 \\
(1.301) \\
\end{array}$ & 1 & 7 \\
\hline $\begin{array}{l}\text { Revised invested } \\
\text { amount }\end{array}$ & $\begin{array}{c}1846.43 \\
(2,764.593) \\
\end{array}$ & $\begin{array}{c}974.87 \\
(1,454.899) \\
\end{array}$ & $\begin{array}{c}1351.34 \\
(2,262.366) \\
\end{array}$ & $\begin{array}{c}874.24 \\
(1,482.704) \\
\end{array}$ & $\begin{array}{c}1266.42 \\
(2,091.268)\end{array}$ & 0 & 10000 \\
\hline $\begin{array}{l}\text { Revised likelihood } \\
\text { of stock price } \\
\text { decrease/increase }\end{array}$ & $\begin{array}{c}8.00 \\
(2.585)\end{array}$ & $\begin{array}{c}6.62 \\
(2.943)\end{array}$ & $\begin{array}{c}7.34 \\
(2.652)\end{array}$ & $\begin{array}{c}7.50 \\
(2.813)\end{array}$ & $\begin{array}{c}7.38 \\
(2.768)\end{array}$ & 1 & 14 \\
\hline $\begin{array}{l}\text { Baseline } \\
\text { impression of } \\
\text { investment }\end{array}$ & $\begin{array}{c}4.60 \\
(1.106)\end{array}$ & $\begin{array}{c}4.33 \\
(1.243)\end{array}$ & $\begin{array}{c}4.78 \\
(1.215)\end{array}$ & $\begin{array}{c}4.33 \\
(1.028)\end{array}$ & $\begin{array}{c}4.51 \\
(1.154)\end{array}$ & 1 & 7 \\
\hline $\begin{array}{l}\text { Baseline invested } \\
\text { amount }\end{array}$ & $\begin{array}{c}2703.69 \\
(2900.946)\end{array}$ & $\begin{array}{c}2218.46 \\
(2355.336)\end{array}$ & $\begin{array}{c}2302.56 \\
(2721.35)\end{array}$ & $\begin{array}{c}2026.02 \\
(2043.269)\end{array}$ & $\begin{array}{c}2314.47 \\
(2517.995)\end{array}$ & 0 & 10000 \\
\hline $\begin{array}{l}\text { Baseline likelihood } \\
\text { of stock price } \\
\text { decrease/increase }\end{array}$ & $\begin{array}{c}9.79 \\
(1.317)\end{array}$ & $\begin{array}{c}9.74 \\
(2.468)\end{array}$ & $\begin{array}{c}9.80 \\
(2.502)\end{array}$ & $\begin{array}{c}10.02 \\
(1.932)\end{array}$ & $\begin{array}{c}9.84 \\
(2.084)\end{array}$ & 2 & 15 \\
\hline Processing fluency & $\begin{array}{c}5.17 \\
(1.034) \\
\end{array}$ & $\begin{array}{c}4.13 \\
(1.508) \\
\end{array}$ & $\begin{array}{c}4.76 \\
(1.392) \\
\end{array}$ & $\begin{array}{c}4.12 \\
(1.329) \\
\end{array}$ & $\begin{array}{c}4.55 \\
(1.385) \\
\end{array}$ & 1 & 7 \\
\hline $\begin{array}{l}\text { Severity of overall } \\
\text { ICW reported }\end{array}$ & $\begin{array}{c}4.64 \\
(1.246) \\
\end{array}$ & $\begin{array}{c}4.69 \\
(1.321) \\
\end{array}$ & $\begin{array}{c}4.44 \\
(1.205) \\
\end{array}$ & $\begin{array}{c}4.67 \\
(1.426)\end{array}$ & $\begin{array}{c}4.61 \\
(1.294)\end{array}$ & 1 & 7 \\
\hline $\begin{array}{l}\text { Likelihood of } \\
\text { material error of } \\
\text { overall ICW } \\
\text { reported }\end{array}$ & $\begin{array}{c}60.95 \\
(18.585)\end{array}$ & $\begin{array}{l}62.05 \\
(18.09)\end{array}$ & $\begin{array}{c}60.24 \\
(20.061)\end{array}$ & $\begin{array}{c}61.43 \\
(21.135)\end{array}$ & $\begin{array}{c}61.16 \\
(19.358)\end{array}$ & 10 & 100 \\
\hline $\begin{array}{l}\text { Reliability of IC } \\
\text { report }\end{array}$ & $\begin{array}{c}3.86 \\
(1.336) \\
\end{array}$ & $\begin{array}{c}3.51 \\
(1.449) \\
\end{array}$ & $\begin{array}{c}3.80 \\
(1.47) \\
\end{array}$ & $\begin{array}{c}3.62 \\
(1.268) \\
\end{array}$ & $\begin{array}{c}3.70 \\
(1.375) \\
\end{array}$ & 1 & 7 \\
\hline $\begin{array}{l}\text { Management } \\
\text { competence }\end{array}$ & $\begin{array}{c}4.36 \\
(1.445) \\
\end{array}$ & $\begin{array}{c}3.97 \\
(1.564)\end{array}$ & $\begin{array}{c}3.85 \\
(1.476)\end{array}$ & $\begin{array}{l}4.12 \\
(1.4)\end{array}$ & $\begin{array}{c}4.08 \\
(1.469) \\
\end{array}$ & 1 & 7 \\
\hline $\begin{array}{l}\text { Management } \\
\text { trustworthiness }\end{array}$ & $\begin{array}{c}4.21 \\
(1.474)\end{array}$ & $\begin{array}{c}3.74 \\
(1.428)\end{array}$ & $\begin{array}{c}3.71 \\
(1.504)\end{array}$ & $\begin{array}{c}3.98 \\
(1.352)\end{array}$ & $\begin{array}{c}3.91 \\
(1.442)\end{array}$ & 1 & 7 \\
\hline $\begin{array}{l}\text { IC understanding } \\
\text { check }\end{array}$ & $\begin{array}{c}3.17 \\
(1.36) \\
\end{array}$ & $\begin{array}{c}2.64 \\
(1.423) \\
\end{array}$ & $\begin{array}{c}2.85 \\
(1.459) \\
\end{array}$ & $\begin{array}{c}2.74 \\
(1.432)\end{array}$ & $\begin{array}{c}2.85 \\
(1.42)\end{array}$ & 1 & 7 \\
\hline $\begin{array}{l}\text { Duration of study } \\
\text { (minutes) }\end{array}$ & $\begin{array}{c}16.41 \\
(12.201)\end{array}$ & $\begin{array}{l}17.12 \\
(7.53)\end{array}$ & $\begin{array}{c}13.75 \\
(6.396)\end{array}$ & $\begin{array}{c}25.73 \\
(67.589)\end{array}$ & $\begin{array}{c}18.30 \\
(35.078)\end{array}$ & 4 & 448 \\
\hline
\end{tabular}




\begin{tabular}{|c|c|c|c|c|c|c|c|c|c|c|c|c|c|c|}
\hline & 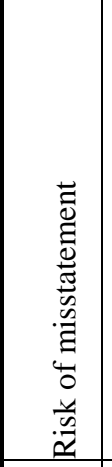 & 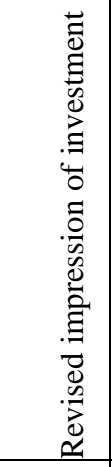 & 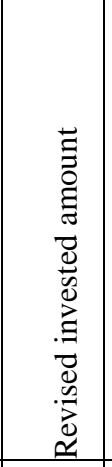 & 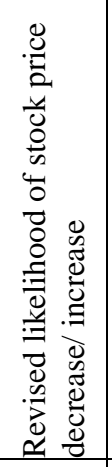 & 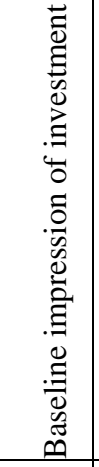 & 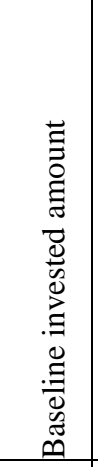 & 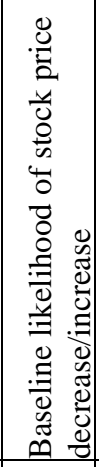 & 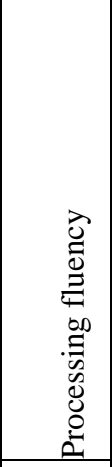 & 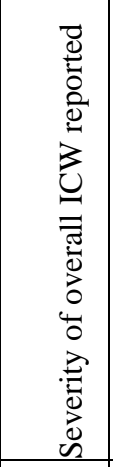 & 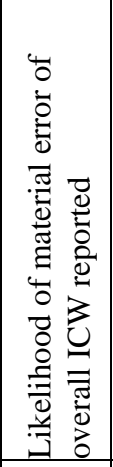 & 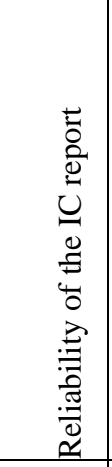 & 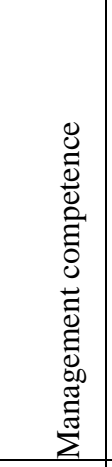 & 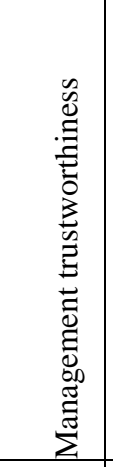 & 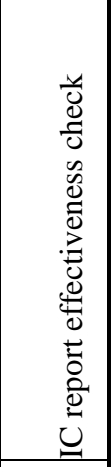 \\
\hline $\begin{array}{l}\text { Risk of } \\
\text { misstatement }\end{array}$ & 1.000 & $-.411^{* *}$ & $-.249^{* *}$ & $-.261^{* *}$ & -.079 & -.015 & .098 & .035 & $.493^{* *}$ & $.409^{* * *}$ & $-.303^{* *}$ & $-.176^{* *}$ & $-.296^{* *}$ & $-.236^{* *}$ \\
\hline $\begin{array}{l}\text { Revised } \\
\text { impression of } \\
\text { investment }\end{array}$ & $-.411^{* *}$ & 1.000 & $.651^{* *}$ & $.616^{* *}$ & $.487^{* *}$ & $.331^{* *}$ & .093 & . 113. & $-.461^{* *}$ & $-.464^{* *}$ & $.460^{* *}$ & $.356^{* *}$ & $.403^{* *}$ & $.230^{* *}$ \\
\hline $\begin{array}{l}\text { Revised } \\
\text { invested amount }\end{array}$ & $-.249^{* *}$ & $.651^{* *}$ & 1.000 & $.579^{* *}$ & $.532^{* *}$ & $.680^{* *}$ & $.287^{* *}$ & $.137^{*}$ & $-.306^{* *}$ & $-.286^{* *}$ & $.376^{* *}$ & $.365^{* *}$ & $.360^{* *}$ & .119 \\
\hline $\begin{array}{l}\text { Revised } \\
\text { likelihood of } \\
\text { stock price } \\
\text { decrease/ } \\
\text { increase }\end{array}$ & $-.261^{* *}$ & $.616^{* *}$ & $.579^{* *}$ & 1.000 & $.360^{* *}$ & $.293^{* *}$ & $.343^{* *}$ & $.155^{* *}$ & $-.331^{* *}$ & $-.247^{* *}$ & $.443^{* *}$ & $.406^{* *}$ & $.465^{* *}$ & $.188^{* *}$ \\
\hline $\begin{array}{l}\text { Baseline } \\
\text { impression of } \\
\text { investment }\end{array}$ & -.079 & $.487^{* *}$ & $.532^{* *}$ & $.360^{* *}$ & 1.000 & $.617^{* *}$ & $.522^{* *}$ & $.318^{* *}$ & -.084 & -.088 & $.216^{* *}$ & $.251^{* *}$ & $.269^{* *}$ & .005 \\
\hline $\begin{array}{l}\text { Baseline } \\
\text { invested amount }\end{array}$ & -.015 & $.331^{* *}$ & $.680^{* *}$ & $.293^{* *}$ & $.617^{* *}$ & 1.000 & $.466^{* *}$ & $.198^{* *}$ & -.021 & -.052 & $.135^{*}$ & $.254^{* *}$ & $.170^{* * *}$ & -.053 \\
\hline $\begin{array}{l}\text { Baseline } \\
\text { likelihood of } \\
\text { stock price } \\
\text { decrease/ } \\
\text { increase }\end{array}$ & .098 & .093 & $.287^{* *}$ & $.343^{* *}$ & $.522^{* *}$ & $.466^{* *}$ & 1.000 & $.244^{* *}$ & .037 & $.185^{* *}$ & .087 & $.262^{* *}$ & .089 & -.031 \\
\hline $\begin{array}{l}\text { Processing } \\
\text { fluency }\end{array}$ & .035 & .113. & $.137^{*}$ & $.155^{* *}$ & $.318^{* *}$ & $.198^{* *}$ & $.244^{* *}$ & 1.000 & .093 & .075 & $.157^{* *}$ & $.234^{* *}$ & $.291^{* *}$ & $-.213^{* *}$ \\
\hline $\begin{array}{l}\text { Severity of } \\
\text { overall ICW } \\
\text { reported }\end{array}$ & $.493^{* * *}$ & $-.461^{* *}$ & $-.306^{* *}$ & $-.331^{* *}$ & -.084 & -.021 & .037 & .093. & 1.000 & $.700^{* *}$ & $-.329^{* *}$ & $-.276^{* *}$ & $-.240^{* *}$ & $-.261^{* *}$ \\
\hline $\begin{array}{l}\text { Likelihood of } \\
\text { material error of } \\
\text { overall ICW } \\
\text { reported }\end{array}$ & $.409^{* *}$ & $-.464^{* *}$ & $-.286^{* *}$ & $-.247^{* *}$ & -.088 & -.052 & $.185^{* *}$ & .075. & $.700^{* *}$ & 1.000 & $-.260^{* *}$ & $-.200^{* *}$ & $-.228^{* *}$ & $-.244^{* *}$ \\
\hline $\begin{array}{l}\text { Reliability of } \\
\text { the IC report }\end{array}$ & $-.303^{* *}$ & $.460^{* *}$ & $.376^{* *}$ & $.443^{* *}$ & $.216^{* *}$ & $.135^{*}$ & .087 & $.157^{* *}$ & $-.329^{* *}$ & $-.260^{* *}$ & 1.000 & $.714^{* *}$ & $.682^{* *}$ & .070 \\
\hline $\begin{array}{l}\text { Management } \\
\text { competence }\end{array}$ & $-.176^{* *}$ & $.356^{* *}$ & $.365^{* *}$ & $.406^{* *}$ & $.251^{* *}$ & $.254^{* *}$ & $.262^{* *}$ & $.234^{* *}$ & $-.276^{* *}$ & $-.200^{* *}$ & $.714^{* *}$ & 1.000 & $.751^{* *}$ & .030 \\
\hline $\begin{array}{l}\text { Management } \\
\text { trustworthiness }\end{array}$ & $-.296^{* *}$ & $.403^{* *}$ & $.360^{* * *}$ & $.465^{* *}$ & $.269^{* *}$ & $.170^{* *}$ & .089 & $.291^{* *}$ & $-.240^{* *}$ & $-.228^{* *}$ & $.682^{* *}$ & $.751^{* *}$ & 1.000 & -.003 \\
\hline $\begin{array}{l}\text { IC report } \\
\text { effectiveness } \\
\text { check }\end{array}$ & $-.236^{* *}$ & $.230^{* *}$ & 119 & $.188^{* *}$ & .005 & -.053 & -.031 & $-.213^{* *}$ & $-.261^{* *}$ & $-.244^{* *}$ & .070 & .030. & -.003 & 1.000 \\
\hline
\end{tabular}




\subsection{Statistical Assumptions}

The statistical tests that were used for hypotheses testing require the use of MANCOVA and ANCOVA. MANCOVA and ANCOVA require certain assumptions to be met to reliably make inferences. The assumptions of MANCOVA include: multivariate normality of the dependent variables and equality of variance-covariance matrices between the experimental conditions for each dependent variable. The assumptions for ANCOVA include normality and homogeneity of variances.

\subsubsection{Tests of Normality}

The multivariate normality assumption of MANCOVA was examined in two ways. First, I examined histogram plots of each dependent variable to determine if the distribution is close to the bell shaped curved. The histogram plots of the four dependent variables are depicted in Figure 5. Examining these plots indicates that the invested amount dependent variable had severe violation of the normality assumption as 78 of the 164 observations had zero values. The rest of the dependent variables appeared to be normally distributed for the overall plots as well as the plots by treatment condition (not depicted). Second, I performed the Shapiro-Wilks test of normality across the treatment conditions. The invested amount dependent variable was not normally distributed across all experimental conditions as assessed by the Shapiro-Wilks test $(\mathrm{p}<.001)$. The Shapiro-Wilks test also revealed that the revised impression of investment was not normally distributed as indicated by significance in the stealth conditions $(\mathrm{p}<.01)$ and salient conditions $(\mathrm{p}<.05)$. Risk of misstatement was normally distributed across all conditions ( $\mathrm{p}>.05)$. Revised likelihood of price decrease/ increase was normally distributed in all but one condition ( $>$.05) - the distribution of this variable in the aggregated/salient condition had a slight normality violation $(\mathrm{p}=.049)$. 


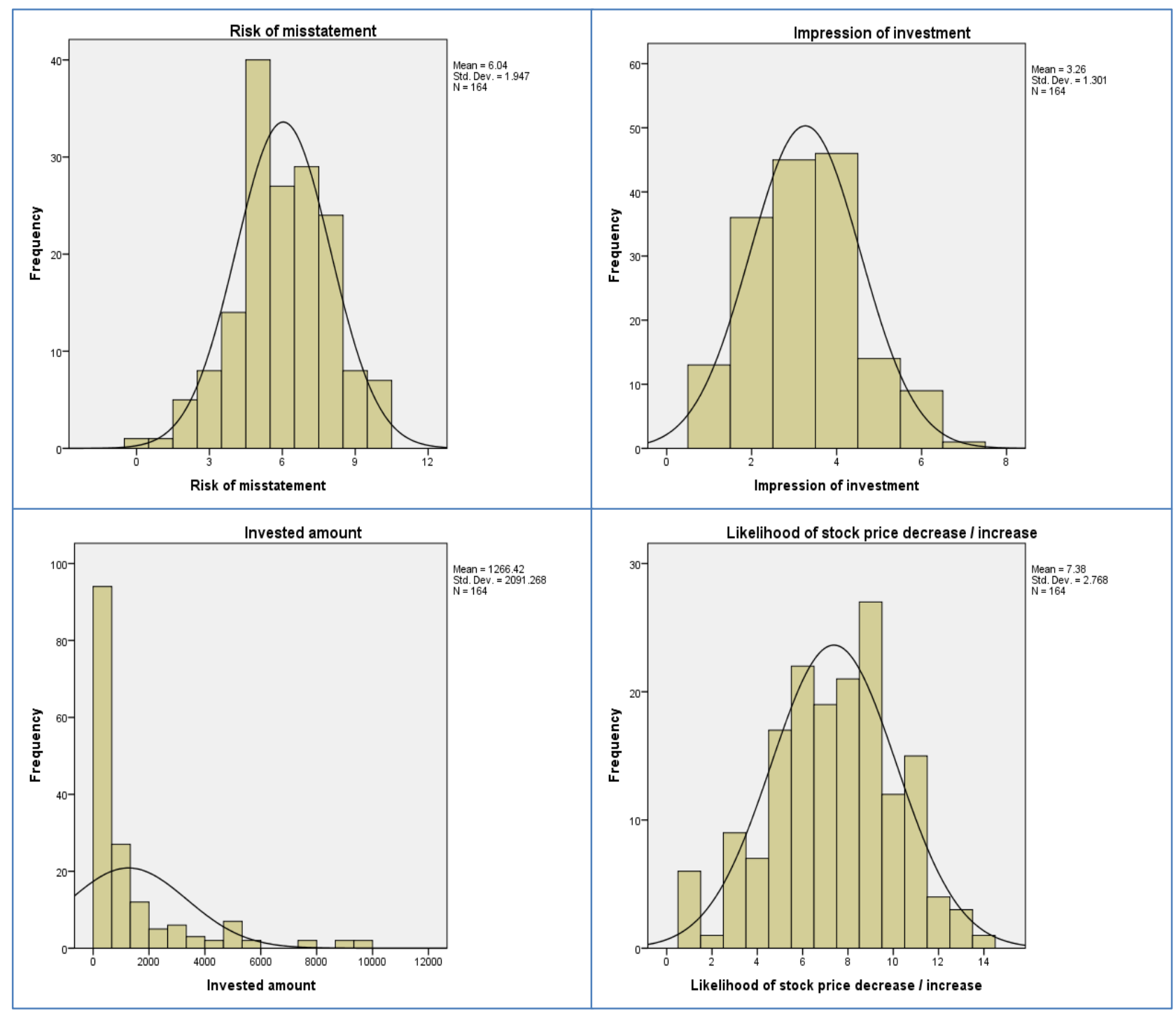

Figure 5. Normality Histogram Plots

MANCOVA and ANCOVA are robust to the normality assumption if the violation of normality is not severe. I was able to judge whether the violation of normality was severe by examining the histogram plots for the variables that were flagged by the significance in the Shapiro-Wilks test of normality. The histograms depicted on Figure 5 indicate that the 
distribution of the impression of investment variable was close to normal ${ }^{17}$; however, the distribution of invested amount was negatively skewed and an extreme violation of normality. As a result, I chose not to rely on the robustness assumption for such an extreme violation of normality and did not include the invested amount variable in the MANCOVA models.

\subsubsection{Tests of Homogeneity of Variance-Covariance Matrices and Equality of Error Variances}

I tested the homogeneity of variance-covariance matrices and the equality of error variances across conditions for MANCOVA and ANCOVA assumptions, respectively. The homogeneity of variance-covariance matrices for dependent variables risk of misstatement, revised impression of investment, and revised likelihood of stock price decrease/increase was assessed using the Box’s M test. Box’s M test is very sensitive and is normally considered significant if the p-value is lower than .001 (Tabachnick and Fidell 2001). The results from Box's test indicated that there is no evidence of violation of homogeneity of variance-covariance matrices $(p=.002)$.

I performed the Levene's test of equality of error variances to test the assumptions for the ANCOVAs that were run following the MANCOVA test. This test was performed on all four dependent variables, including the revised invested amount variable, since outcome differences across experimental conditions were also tested using ANCOVA models. The results on the Levene's test of equality of error variances indicates that the equality of error variances assumption was not violated for any dependent variable ( $\mathrm{p}>.05)$.

\footnotetext{
${ }^{17}$ Exclusion of the impression of investment variable leads to qualitatively similar (stronger) results and the MANCOVA model/interaction remain significant (stronger).
} 


\subsection{Tests of Hypotheses}

Hypothesis testing was performed using a MANCOVA model followed by separate ANCOVA analyses on the misstatement risk variable and the investing judgment variables. The dependent variables that are initially tested in the MANCOVA model are risk of misstatement, revised impression of investment, and revised likelihood of stock price decrease/increase ${ }^{18}$. The MANCOVA (as opposed to a MANOVA) model in the pre-post experimental design is necessary because the interest of this study is in interpreting the final investing judgments, ceteris paribus, which would require controlling for baseline assessments. I use the revised assessments as dependent variables and control for the baseline statistically instead of constructing difference scores in the dependent variable. The reasoning for using the revision dependent variables with baseline covariates is the benefit of allowing the coefficient on each observation to vary rather than assuming that the coefficient is fixed. Additionally, the use of difference scores between dependent variables has the draw back that assumes that revisions are similar regardless of whether the initial baseline is closer to the floor or ceiling of the scales and follows the assumption that all participants are affected similarly by their initial assessments regardless of their baseline scores).

Hypothesis 1 and 2 posit that there will be a main effect of presentation salience of ICWs disclosed in IC reports on the risk of misstatement and investing judgments such that nonprofessional investors viewing an IC report that clearly identifies the diagnostic information (bulleted material weakness disclosure) will respond less negatively to the internal control weakness than those viewing an IC report that less clearly identifies the diagnostic information

\footnotetext{
${ }^{18}$ The revised invested amount variable was left out of the MANCOVA model due to severe violation of normality and inability to use its related baseline invested amount variable as a covariate due to multi-collinearity concerns.
} 
(in-text material weakness disclosure). As a preliminary step, I used Spearman coefficients of correlation to conduct univariate tests between the salience independent variable and each of the four dependent variables. Salience was significantly correlated with revised impression of investment ( $\mathrm{p}=.009)$ and revised invested amount $(\mathrm{p}=.085)$. Salience was marginally significantly correlated with revised likelihood of stock price decrease/increase $(\mathrm{p}=.104)$ and risk of misstatement ( $\mathrm{p}=.103)$. The descriptive statistics tabulated on Table 5.5 indicate that the means in the salient conditions for the dependent variables are more favorable than the means in stealth conditions. ANOVA tests on the revised and baseline investment judgment variables indicate that salience was significant (one-tailed $\mathrm{p}<.05$ ) across all the revised dependent variables and the baseline variable for impression of investment $(\mathrm{p}<.05)$. An ANCOVA model testing the main effect of salience on revised impression of investment with salience included as a factor and baseline of impression of investment inserted as a covariate returns a significant overall model $(\mathrm{p}<.001)$, and salience remains significant $(\mathrm{p}=.035)$. The preliminary evidence of the main effect of salience on the risk of misstatement and investing judgments was followed by controlled multivariate tests.

The dependent variables that are included in the MANCOVA test are risk of misstatement, revised impression of investment, and revised likelihood of stock price decrease/increase. The result of the MANCOVA test is included in Table 5.6. There was a significant interaction between salience and disaggregation in the MANCOVA model $(\mathrm{p}<.10)$. This indicates that there are statistically significant differences in the means across the conditions even after accounting for the correlation among the dependent variables in the study. To further investigate the significance of the interaction between the two independent variables, individual ANCOVA models are required to tease out the dependent variables that might be driving the 
results. The main effects in the MANCOVA are not interpretable when the interaction is significant; however, if the interaction in a subsequent ANCOVA test is not significant, the main effects can be interpreted to test Hypotheses.

\begin{tabular}{|c|c|c|c|c|c|c|c|c|}
\hline \multicolumn{9}{|c|}{ Panel A. Descriptive statistics by presentation salience } \\
\hline \multicolumn{2}{|c|}{ Presentation salience } & $\begin{array}{c}\text { Risk of } \\
\text { misstatement }\end{array}$ & $\begin{array}{l}\text { Revised } \\
\text { impression } \\
\text { of } \\
\text { investment }\end{array}$ & $\begin{array}{c}\text { Revised } \\
\text { invested } \\
\text { amount }\end{array}$ & $\begin{array}{l}\text { Revised } \\
\text { likelihood } \\
\text { of stock } \\
\text { price } \\
\text { decrease/ } \\
\text { increase } \\
\end{array}$ & $\begin{array}{l}\text { Baseline } \\
\text { impression } \\
\text { of } \\
\text { investment }\end{array}$ & $\begin{array}{c}\text { Baseline } \\
\text { invested } \\
\text { amount }\end{array}$ & $\begin{array}{c}\text { Baseline } \\
\text { likelihood } \\
\text { of stock } \\
\text { price } \\
\text { decrease/ } \\
\text { increase }\end{array}$ \\
\hline \multirow[t]{3}{*}{ Stealth } & Mean & 6.30 & 2.98 & 922.69 & 7.07 & 4.33 & 2118.68 & 9.89 \\
\hline & S.d. & $(1.907)$ & (1.193) & $(1461.059)$ & $(2.893)$ & $(1.129)$ & $(2187.267)$ & $(2.197)$ \\
\hline & $\mathrm{N}$ & 81 & 81 & 81 & 81 & 81 & 81 & 81 \\
\hline \multirow[t]{3}{*}{ Salient } & Mean & 5.78 & 3.54 & 1601.87 & 7.67 & 4.69 & 2505.54 & 9.80 \\
\hline & S.d. & $(1.963)$ & $(1.346)$ & (2525.913) & $(2.623)$ & $(1.157)$ & $(2803.750)$ & $(1.980)$ \\
\hline & $\mathrm{N}$ & 83 & 83 & 83 & 83 & 83 & 83 & 83 \\
\hline \multirow{2}{*}{$\begin{array}{l}\text { Difference } \\
\text { (Salient } \\
\text { vs. } \\
\text { Stealth) }\end{array}$} & Diff. & -0.51 & 0.57 & 679.18 & 0.60 & 0.35 & 386.86 & -0.09 \\
\hline & $\begin{array}{l}\text { Sig. (1- } \\
\text { tailed) }\end{array}$ & $p=0.046$ & $p=0.003$ & $p=0.019$ & $p=0.083$ & $p=0.025$ & $p=0.164$ & $p=0.387$ \\
\hline \multicolumn{9}{|c|}{ Panel B. Spearman coefficient of correlation } \\
\hline \multicolumn{2}{|c|}{$\begin{array}{l}\text { Independent } \\
\text { variable }\end{array}$} & $\begin{array}{c}\text { Risk of } \\
\text { misstatement }\end{array}$ & $\begin{array}{l}\text { Revised } \\
\text { impression } \\
\text { of } \\
\text { investment }\end{array}$ & $\begin{array}{c}\text { Revised } \\
\text { invested } \\
\text { amount }\end{array}$ & $\begin{array}{l}\text { Revised } \\
\text { likelihood } \\
\text { of stock } \\
\text { price } \\
\text { decrease/ } \\
\text { increase } \\
\end{array}$ & $\begin{array}{l}\text { Baseline } \\
\text { impression } \\
\text { of } \\
\text { investment }\end{array}$ & $\begin{array}{c}\text { Baseline } \\
\text { invested } \\
\text { amount }\end{array}$ & $\begin{array}{c}\text { Baseline } \\
\text { likelihood } \\
\text { of stock } \\
\text { price } \\
\text { decrease/ } \\
\text { increase }\end{array}$ \\
\hline \multirow{3}{*}{ Salience } & Coefficient & -.128 & 0.202 & .127 & .135 & .153 & .032 & -.053 \\
\hline & $\begin{array}{l}\text { Sig. (2- } \\
\text { tailed) }\end{array}$ & .103 & .009 & .104 & .085 & .051 & .683 & .497 \\
\hline & $\mathrm{N}$ & 164 & 164 & 164 & 164 & 164 & 164 & 164 \\
\hline
\end{tabular}

The purpose of MANCOVA and ANCOVA differ in that while MANCOVA tries to explain the variation in the latent unobserved construct represented by the dependent variables, ANCOVA directly tests whether the means of each observed dependent variable varies across 
the treatment conditions (Haase and Ellis 1987; Huberty and Morris 1989; Warne 2014).

Therefore, while the MANCOVA can help us understand whether salience and disaggregation affect all investing judgments, the ANCOVA can determine which one of the investing judgments are affected by the factors or a combination of the factors. Additionally, independent ANCOVAs have the advantage of additional power since one can include (exclude) certain variables that may only be related to some dependent variables but not related to others.

\begin{tabular}{|c|c|c|c|c|c|c|}
\hline \multicolumn{2}{|l|}{ Effect } & Value & $\mathrm{F}$ & Hypothesis df & Error df & Sig. \\
\hline \multirow{2}{*}{ Intercept } & Pillai's Trace & 0.374 & $31.049^{b}$ & 3 & 156 & 0.000 \\
\hline & Wilks' Lambda & 0.626 & $31.049^{b}$ & 3 & 156 & 0.000 \\
\hline \multirow{2}{*}{$\begin{array}{l}\text { Baseline likelihood of } \\
\text { stock price decrease/ } \\
\text { increase }\end{array}$} & Pillai's Trace & 0.204 & $13.291^{b}$ & 3 & 156 & 0.000 \\
\hline & Wilks' Lambda & 0.796 & $13.291^{\mathrm{b}}$ & 3 & 156 & 0.000 \\
\hline \multirow{2}{*}{$\begin{array}{l}\text { Baseline impression of } \\
\text { investment }\end{array}$} & Pillai's Trace & 0.287 & $20.960^{b}$ & 3 & 156 & 0.000 \\
\hline & Wilks' Lambda & 0.713 & $20.960^{b}$ & 3 & 156 & 0.000 \\
\hline \multirow{2}{*}{ Disaggregated } & Pillai's Trace & 0.000 & $.024^{\mathrm{b}}$ & 3 & 156 & 0.995 \\
\hline & Wilks' Lambda & 1.000 & $.024^{\mathrm{b}}$ & 3 & 156 & 0.995 \\
\hline \multirow{2}{*}{ Salience } & Pillai's Trace & 0.024 & $1.256^{\mathrm{b}}$ & 3 & 156 & 0.292 \\
\hline & Wilks' Lambda & 0.976 & $1.256^{\mathrm{b}}$ & 3 & 156 & 0.292 \\
\hline \multirow{2}{*}{ Disaggregated*Salience } & Pillai's Trace & 0.042 & $2.267^{b}$ & 3 & 156 & 0.083 \\
\hline & Wilks' Lambda & 0.958 & $2.267^{\mathrm{b}}$ & 3 & 156 & 0.083 \\
\hline \multicolumn{7}{|c|}{$\begin{array}{l}\text { a. Risk of misstatement, revised likelihood of stock price decrease/ increase, revised impression of investment: Intercept + baseline } \\
\text { likelihood of stock price decrease/ increase + baseline impression of investment + disaggregated + salience + disaggregated * salience } \\
\text { b. Exact statistic }\end{array}$} \\
\hline
\end{tabular}

\subsubsection{Risk of Misstatement (Tests of Hypotheses 1 and 3)}

I ran a separate ANCOVA model to test whether there was a main effect of ICW presentation salience on risk of misstatement. The covariate inclusion criteria that was discussed in the correlation analysis section (5.4) was followed to select covariates. The following covariates are significantly correlated with risk of misstatement: Severity of overall ICW reported, Likelihood of material error of overall ICW reported, Reliability of IC report, 
Management trustworthiness, Management competence, IC understanding check, ICFR influences my investing decision, and MD\&A reading frequency. Upon further investigation of these potential covariates, multiple correlation analysis indicated that several variables were highly correlated (coefficients $>$.60): (i) Severity of overall ICW reported with Likelihood of material error of overall ICW reported, (ii) Reliability of IC report with Management trustworthiness, and Management competence. Since these variables possibly measured the same construct, I included just Severity of overall ICW reported and Reliability of IC report in subsequent models. Additionally, to satisfy the conditions of an effective ANCOVA, any significant correlation between a covariate and the independent variables or another covariate that exceeded a coefficient of .20 led to the removal of that covariate (Evans 1996) ${ }^{19}$.

Inclusion of the potential covariates in an ANCOVA model revealed that several variables that were significantly correlated with risk of misstatement were not significant. Other potential covariates that were correlated with each other were included in the model one at the time. The most parsimonious model that is listed below was used to test the hypotheses related to the risk of misstatement $(\mathrm{H} 1 \& \mathrm{H} 3)$. Table 5.7 shows that the main effect of salience was significant in the model $(p<.10)$. Therefore, in a multivariate setting that incorporates ICW disaggregation type, I find support for Hypothesis 1 that presentation salience of ICWs leads to a lower perception of risk of misstatement by nonprofessional investors.

Risk of Misstatement $=\beta_{0}+$ Salience + Disaggregation

+ Salience $*$ Disaggregation + Severity of overall ICW reported + MD\&A reading frequency

\footnotetext{
${ }^{19}$ Covariates that were correlated were each included in the original pre-post model without other covariates. None
} of the covariates included led to loss of significance on the factors and led to qualitatively similar findings. 


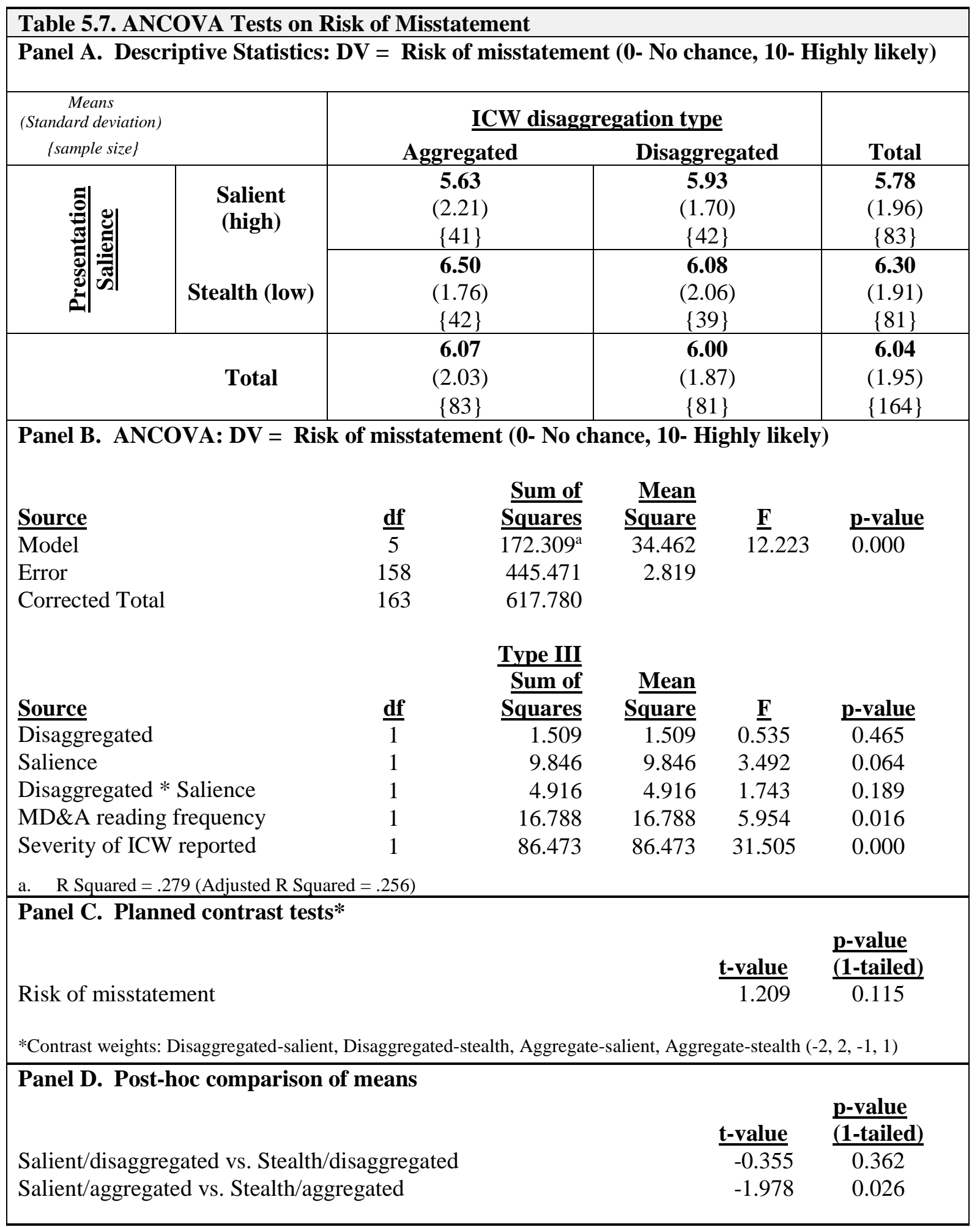


Hypothesis 3 posits that there will be an interaction between ICW presentation salience and ICW disaggregation type such that the mean risk of misstatement differs by salience only when the ICW disaggregation type is disaggregated (multiple control deficiencies that aggregate to one material weakness). Table 5.7 presents the model used to test whether the interaction was significant in the ANCOVA model. The lack of significance on the interaction between salience and disaggregation indicates that the effect of salience on the risk of misstatement does not depend on whether the ICW is disaggregated $(p=.12)$. A planned contrast test of the patterns predicted in hypothesis 3 (in conjunction with hypothesis 1 ) was also not significant $(p>.10)^{20}$; thus, no support is provided for Hypothesis 3. Figure 6 depicts the findings related to risk of misstatement.

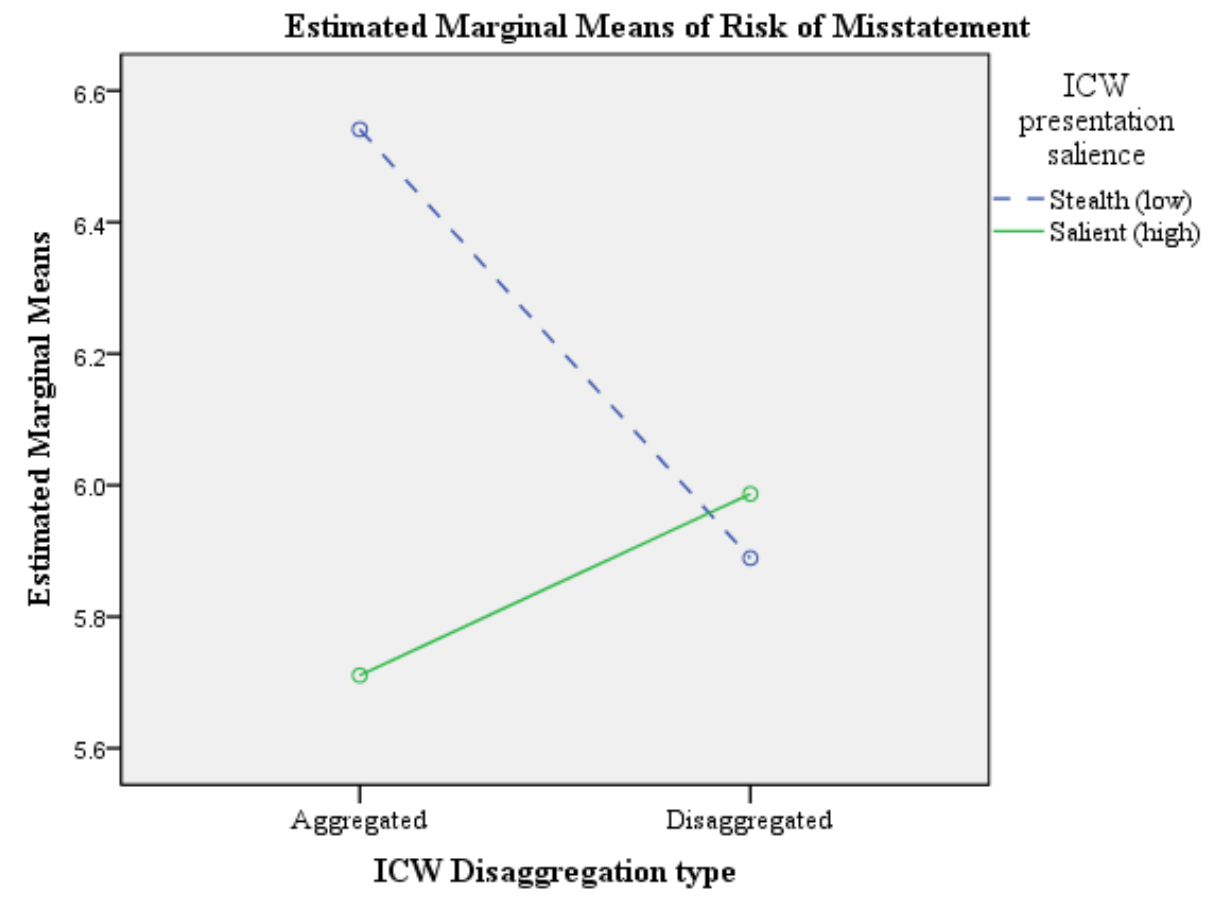

Figure 6. Means of Risk of Misstatement

\footnotetext{
${ }^{20}$ The planned contrast was likely closer to significance due to the main effect test of salience built into the test. Contrast weights: Disaggregated-salient, Disaggregate-stealth, Aggregate-salient, Aggregate-stealth $(-2,2,-1,1)$
} 
In a search for an alternative explanation for the nearly significant interaction variable and pattern depicted on Figure 6, I performed two post-hoc t-tests ${ }^{21}$ by comparing salient/aggregated vs. stealth/aggregated and salient/disaggregated vs. stealth/disaggregated. The 1-tailed t-test statistic was not significant in the test that compared salient/disaggregated vs. stealth/disaggregated $(\mathrm{p}=.362)$. Interestingly, the 1-tailed t-test (one-tailed) was significant in the test that compared salient/aggregated vs. stealth/aggregated ( $p=.026)$. This finding provides support for the notion that there is an interaction between salience and disaggregation; however, salience is only important when the ICW is in an aggregated format. One potential explanation for the result that aggregation matters is likely due to the operationalization of aggregation. Higher risk of misstatement is likely associated with aggregation since the ICW is disclosed as a material weakness in the aggregated condition. Therefore, in considering the risk of a "material" misstatement, investors may be primed to think of materiality, and thus may be more likely to be affected when a "material" weakness is present. Moreover, this should lead investors to expect a weakness that is material (important in this sense) to be presented saliently but not so when the material weakness is a result of multiple control deficiencies.

\subsubsection{Investing Judgments (Tests of Hypotheses 2 and 4)}

Hypotheses 2 and 4 deal with the effect of ICW presentation salience and ICW disaggregation type on investing judgments. These hypotheses were tested using separate ANCOVA models for the three investing judgment dependent variables that were captured. Similar to the risk of misstatement model, covariates included for each dependent variable were determined based on multiple correlational analyses. The covariate inclusion criteria that were

\footnotetext{
${ }^{21}$ I performed two planned test instead of pairwise comparisons to avoid testing comparisons that are not of interest. Performing pairwise comparisons reduces power to control for the experiment wise error rate.
} 
discussed in the correlation analysis section (5.4) were followed to select covariates. The results for the tests of Hypotheses 2 and 4 will be presented following the subsections discussing the separate tests on the investing judgment dependent variables.

\subsubsection{Impression of investment}

Multiple correlational analyses between impression of investing and possible covariates indicated that the dependent variable has significant correlation with: Severity of overall ICW reported, Likelihood of material error of overall ICW reported, Reliability of IC report, Management trustworthiness, Management competence, IC understanding check, ICFR influences my investing decision, Risk preference, Trading frequency, and Investor dormant (months). Trading frequency was significantly correlated with the salience factor and was subsequently removed after noting that the ANCOVA model with only baseline impression is not qualitatively affected by including trading frequency as an additional covariate. As indicated before, likelihood of material error and the management trust and competence variables were removed from the ANCOVA model to avoid multi-collinearity issues. Due to the significant correlations among Severity of overall ICW reported, IC understanding check and Reliability of IC report, the variables were included in the model one at a time. The effect of each variable was quantitatively similar; therefore, I selected the severity variable based on theoretical expectations and literature that indicates severity as an important variable. . The most parsimonious model for the tests performed using impression of investment as a dependent is listed below and included on Table 5.8.

$$
\begin{aligned}
& \text { Revised Impression of Investment }=\beta_{0}+\text { Salience }+ \text { Disaggregation } \\
& + \text { Salience } * \text { Disaggregation }+ \text { Baseline Impression of Investment } \\
& + \text { Severity of overall ICW reported }+ \text { Investor dormant }
\end{aligned}
$$




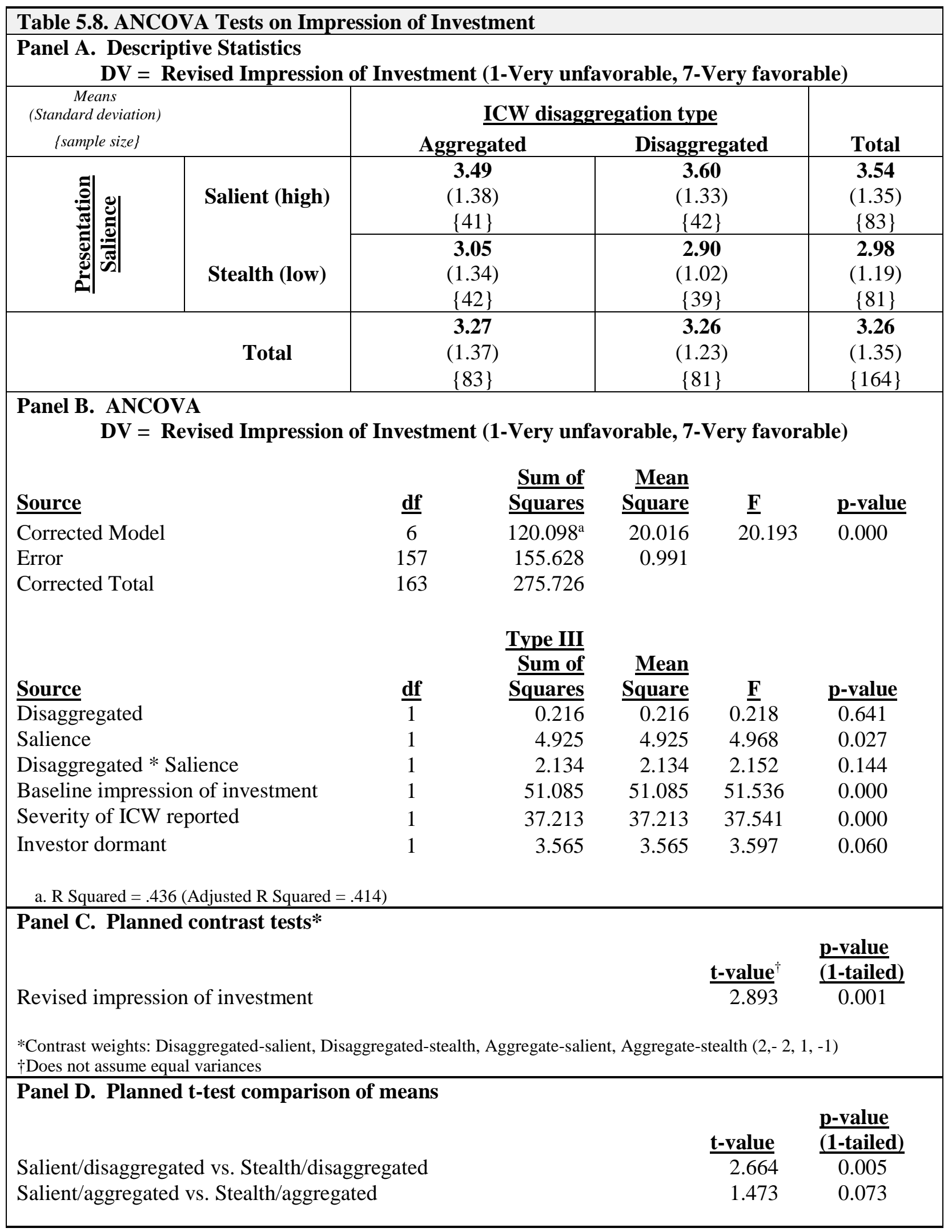


Tests of significance on the main effect of salience on investing judgments (Hypothesis $2)$ is supported for the impression of investment measure $(p=.027)$. The presentation of diagnostic ICW information in a salient manner was viewed favorably by participants when compared to the less salient form of communicating the same ICW information. This finding provides support for hypothesis 2 as it relates to the impression of investment variable. Tests of the interaction of salience and disaggregation indicated that the interaction variable was not significant in the ANCOVA model.

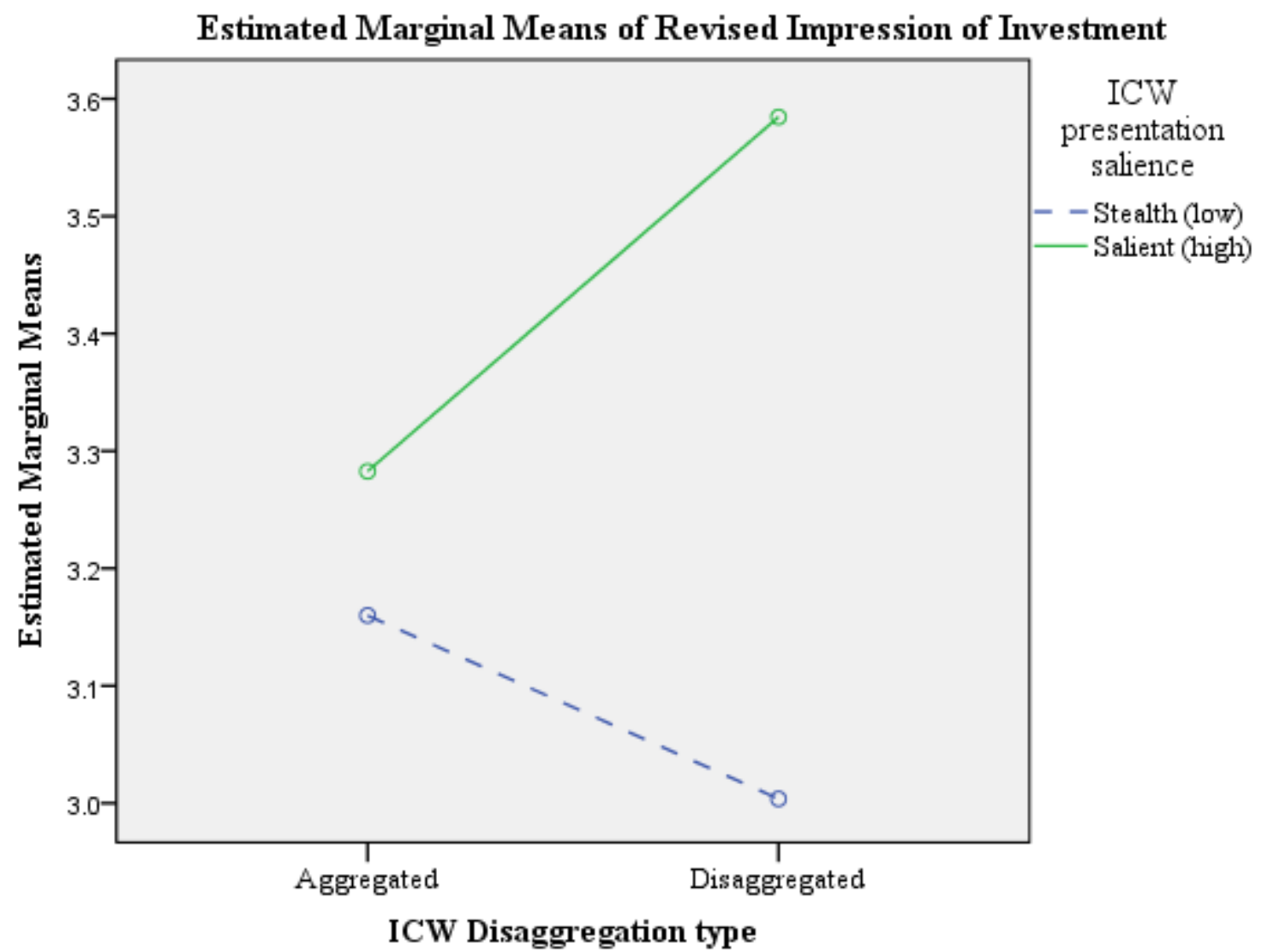

Figure 7. Means of Revised Impression of Investment 
A planned contrast test was performed to test Hypothesis 4 as it relates to impression of investment ${ }^{22}$. The planned contrast test that is presented in Panel C of Table 5.8 provides support for Hypothesis 4, in that the effect of salience on investing was amplified when the disaggregation type is disaggregated ( $p=.002)$. Additional post-hoc Bonferroni comparison of means (not tabulated) indicates that the only significant difference $(p=.046)$ between salient and stealth conditions was when these conditions were of disaggregated type (MW due to combination of control deficiencies). Hypothesis 4 as it related to impression of investment was supported. Figure 7 depicts the means of impression of investment across the experimental conditions.

\subsubsection{Likelihood of stock price decrease / increase}

Multiple correlational analyses between likelihood of stock price decrease/increase and possible covariates indicated that this dependent variable was significantly correlated with: Severity of overall ICW reported, Likelihood of material error of overall ICW reported, Reliability of IC report, Management trustworthiness, Management competence, IC understanding check, ICFR influences my investing decision, Risk preference, Reliance on financial advisors, and Investor dormant (months). As indicated before, likelihood of material error and the management trust and competence variables were removed from the ANCOVA model to avoid multi-collinearity issues. Risk preference and IC report understanding check were not significant in the model and were consequently removed. Due to the significant correlation between Severity of overall ICW reported and Reliability of IC report, the variables were inserted one at a time and produced qualitatively similar results on the significance of the

\footnotetext{
22 Planned contrast weights for all investing judgment models: Disaggregated-salient, Disaggregate-stealth, Aggregate-salient, Aggregate-stealth (2, -2, 1, -1)
} 
factors. The most parsimonious model for the tests performed using revised likelihood of stock price decrease/increase as a dependent variable is presented below Table 5.9.

\begin{tabular}{|c|c|c|c|c|}
\hline \multicolumn{5}{|c|}{$\begin{array}{l}\text { Panel A. Descriptive statistics: DV = Revised likelihood of price decrease / increase (-7 High } \\
\text { likelihood of decline, } 0 \text { No change, }+7 \text { High likelihood of price increase; recoded as 1-15) }\end{array}$} \\
\hline \multirow{2}{*}{\multicolumn{2}{|c|}{$\begin{array}{c}\text { Means } \\
\text { (Standard deviation) } \\
\text { \{sample size } \\
\end{array}$}} & \multirow{2}{*}{\multicolumn{2}{|c|}{$\begin{array}{l}\frac{\text { ICW disaggregation type }}{\text { Aggregated }} \quad \text { Disaggregated }\end{array}$}} & \multirow{3}{*}{$\begin{array}{c}\text { Total } \\
7.67 \\
(2.62) \\
\{83\} \\
\end{array}$} \\
\hline & & & & \\
\hline \multirow{2}{*}{ 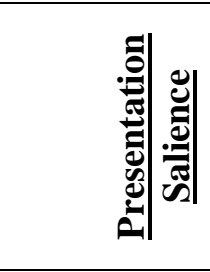 } & Salient (high) & $\begin{array}{c}7.34 \\
(2.65) \\
\{41\} \\
\end{array}$ & $\begin{array}{c}\mathbf{8 . 0 0} \\
(2.59) \\
\{42\} \\
\end{array}$ & \\
\hline & Stealth (low) & $\begin{array}{c}7.50 \\
(2.81) \\
\{42\} \\
\end{array}$ & $\begin{array}{c}\mathbf{6 . 6 2} \\
(2.94) \\
\{39\} \\
\end{array}$ & $\begin{array}{c}7.07 \\
(2.89) \\
\{81\} \\
\end{array}$ \\
\hline \multicolumn{2}{|r|}{ Total } & $\begin{array}{c}7.42 \\
(2.72) \\
\{83\} \\
\end{array}$ & $\begin{array}{c}7.33 \\
(2.83) \\
\{81\} \\
\end{array}$ & $\begin{array}{c}7.38 \\
(2.77) \\
\{164\} \\
\end{array}$ \\
\hline
\end{tabular}

Panel B. ANCOVA: DV = Revised likelihood of price decrease $/$ increase $(-7$ High likelihood of decline, 0 No change, +7 High likelihood of price increase; recoded as 1-15)

\begin{tabular}{|c|c|c|c|c|c|}
\hline Source & $\underline{\text { df }}$ & $\underline{\text { Sum of }}$ & $\underline{\text { Mean }}$ & $\underline{\mathbf{F}}$ & p-value \\
\hline Corrected Model & 6 & $359.732^{\mathrm{a}}$ & 59.955 & 10.590 & 0.000 \\
\hline Error & 157 & 888.829 & 5.661 & & \\
\hline \multirow[t]{2}{*}{ Corrected Total } & 163 & 1248.561 & & & \\
\hline & df & $\frac{\text { Type III }}{\text { Sum of }}$ & $\underline{\text { Mean }}$ & $\mathbf{F}$ & p-value \\
\hline$\overline{\text { Disaggregated }}$ & $\overline{1}$ & 0.064 & 0.064 & $0 . \overline{011}$ & 0.915 \\
\hline Salience & 1 & 12.222 & 12.222 & 2.159 & 0.144 \\
\hline Disaggregated * Salience & 1 & 16.162 & 16.162 & 2.855 & 0.093 \\
\hline $\begin{array}{l}\text { Baseline likelihood of price } \\
\text { decrease/increase }\end{array}$ & 1 & 140.513 & 140.513 & 24.820 & 0.000 \\
\hline Severity of ICW reported & 1 & 106.046 & 106.046 & 18.732 & 0.000 \\
\hline Reliance on financial advisors & 1 & 35.633 & 35.633 & 6.294 & 0.013 \\
\hline
\end{tabular}

a. R Squared $=.288$ (Adjusted R Squared $=.261$ )

\section{Panel C. Planned contrast tests*}

Revised likelihood of price decrease/increase

${\frac{\text { t-value }^{\dagger}}{1.915}}^{\dagger} \quad \frac{\begin{array}{c}\text { p-value } \\ \text { (1-tailed) }\end{array}}{0.029}$

*Contrast weights: Disaggregated-salient, Disaggregated-stealth, Aggregate-salient, Aggregate-stealth (2,- 2, 1, -1) $\dagger$ Assumes equal variances

Panel D. Post-hoc comparison of means

Salient/disaggregated vs. Stealth/disaggregated

\begin{tabular}{lc} 
Tests & $\begin{array}{l}\text { p-value } \\
\text { (1-tailed) }\end{array}$ \\
\hline Bonferonni & 0.075 \\
Tukey & 0.056
\end{tabular}


Revised Likelihood of Stock Price Decrease/Increase $=\beta_{0}+$ Salience + Disaggregation

+ Salience $*$ Disaggregation + Baseline Likelihood of Stock Price Decrease/Increase

+ Severity of overall ICW reported + Relianceon financial advisors

The results of the ANCOVA analyses listed on Table 5.9 indicate that there was a significant interaction between salience and disaggregation $(p<.10)$. The main effect of salience is not significant in the ANCOVA model ( $p=.144)$. Hypothesis 2 predicting a main effect of salience on investing judgments is not supported for this dependent variable. Hypothesis 4 predicts that there is an interaction such that the type of disaggregation determines the importance of salience. Support for Hypothesis 4 is confirmed through a Bonferonni post-hoc comparison of means $(p=.075)$ and a planned contrast test $(p=.029)$. Hypothesis 4 is supported for this dependent variable. The pattern of means for the revised likelihood of stock price decrease/increase variable is depicted on Figure 8.

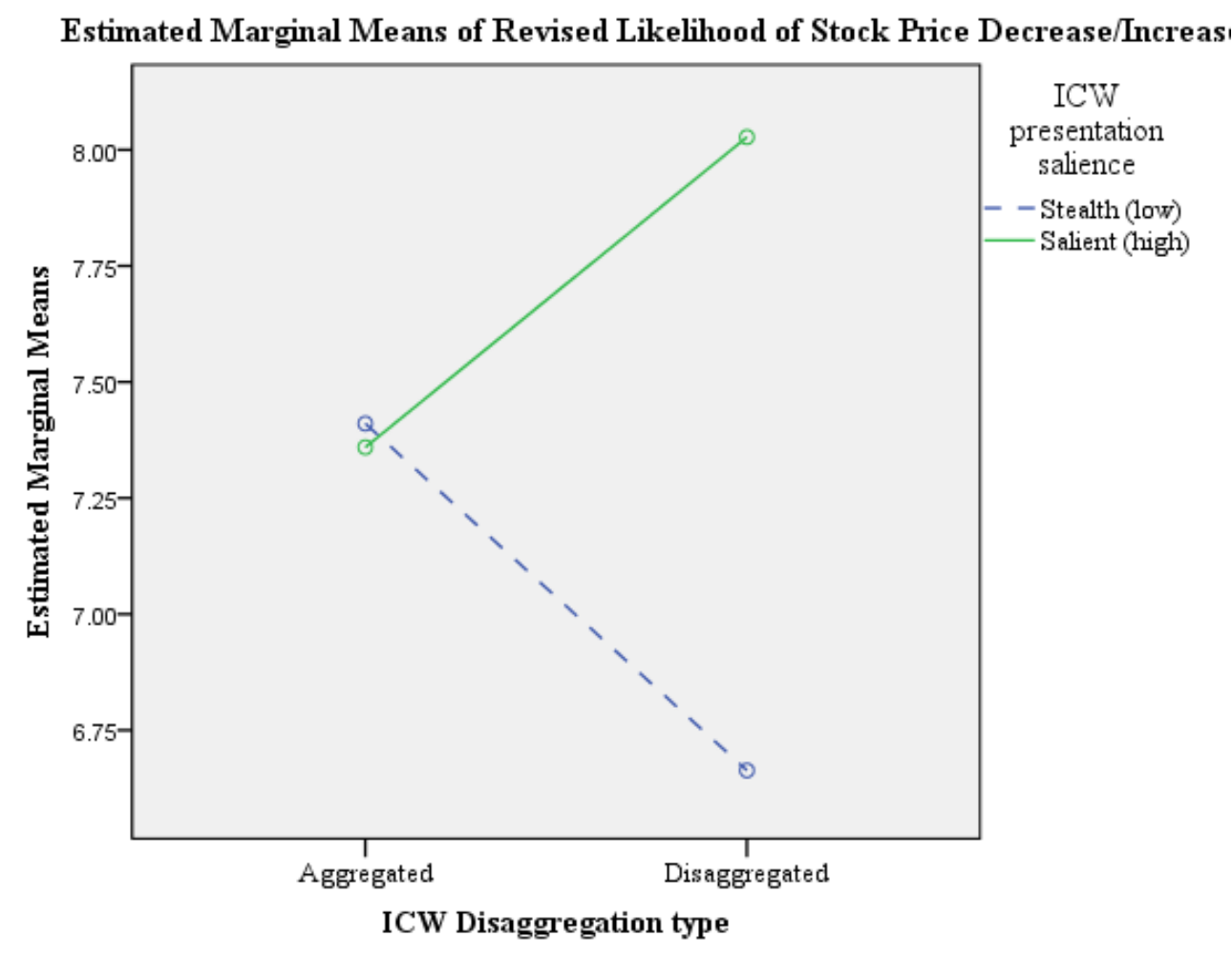

Figure 8. Means of Revised Likelihood of Stock Price Decline/Increase 


\subsubsection{Investment amount}

The investing amount dependent variable was not included in the MANCOVA that was initially performed due to severe violation of normality. Further investigation of the data revealed that there were 36 participants who initially stated that they would not invest any of their \$10,000 inheritance (baseline investment amount) prior to the revelation of a material weakness disclosure. This floor effect prevented 36 of the participants from revising the investment amount downward and accounted for 36 of the 78 zeros that were contributing to the zero inflation problem on the revised investment amount variable. To confirm that the floor effect was driven due to risk preferences of the participants, a comparison of means of the risk preferences covariate was performed between the participants who initially chose not to invest their inheritance and those who selected an amount greater than zero. The results of the one-way ANOVA indicated that the mean risk preference for the group that chose not to invest was .22 which was significantly lower than the mean of .78 for the group that initially chose to invest $(p=.001)$. Although ANCOVA is robust to violations of normality, I analyzed the data with both the full sample and the non-zero baseline sample of 128 observations ${ }^{23}$ on subsequent analysis to provide confidence of the effectiveness of the ANCOVA on the revised investment dependent variable.

Multiple correlational analyses was used to identify variables that were significantly correlated with the revised investment amount dependent variable. Severity of overall ICW reported, Likelihood of material error of overall ICW reported, Reliability of IC report, Management trustworthiness, Management competence, IC understanding check, Risk preference, and Reliance on financial advisors were significantly correlated with Revised

\footnotetext{
${ }^{23}$ ANCOVA models using the entire dataset produced qualitatively similar results and salience remains significant $(\mathrm{p}=.032)$.
} 
investment amount. IC understanding check was correlated with both Risk preference and Severity of overall ICW reported. Reliance on financial advisors and Risk preference were not significant in the model and were subsequently removed. The parsimonious model that is shown below is used to perform statistical tests that are included in Table 5.10.

Revised Investment Amount $=\beta_{0}+$ Salience + Disaggregation + Salience $*$ Disaggregation + Baseline Investment Amount + Severity of overall ICW reported

The results of the ANCOVA test indicated that the overall model was significant $(p<.001)$. The effect of salience was statistically significant $(p=.041)$ and indicated that the mean investment amount in salient conditions was significantly higher than that in stealth conditions. Hypothesis 2 was supported as it related to the investment amount dependent variable. A planned contrast test was performed to test Hypothesis 4 and Hypothesis 2 together. The planned contrast indicated that the model is statistically significant in the predicted direction of means across conditions ( $p=.0195$, one-tailed). Additionally, two planned t-test comparisons were performed to test whether the salient and stealth conditions were significantly different only in the disaggregated conditions. The difference between salience and stealth conditions was significant within the disaggregated conditions ( $p=.039$, one-tailed) but not in the aggregated conditions ( $p=.131)$. Hypothesis 4 was supported as it related to the investment amount dependent variable. Figure 9 depicts the pattern of the means of revised invested amount dependent variable. 


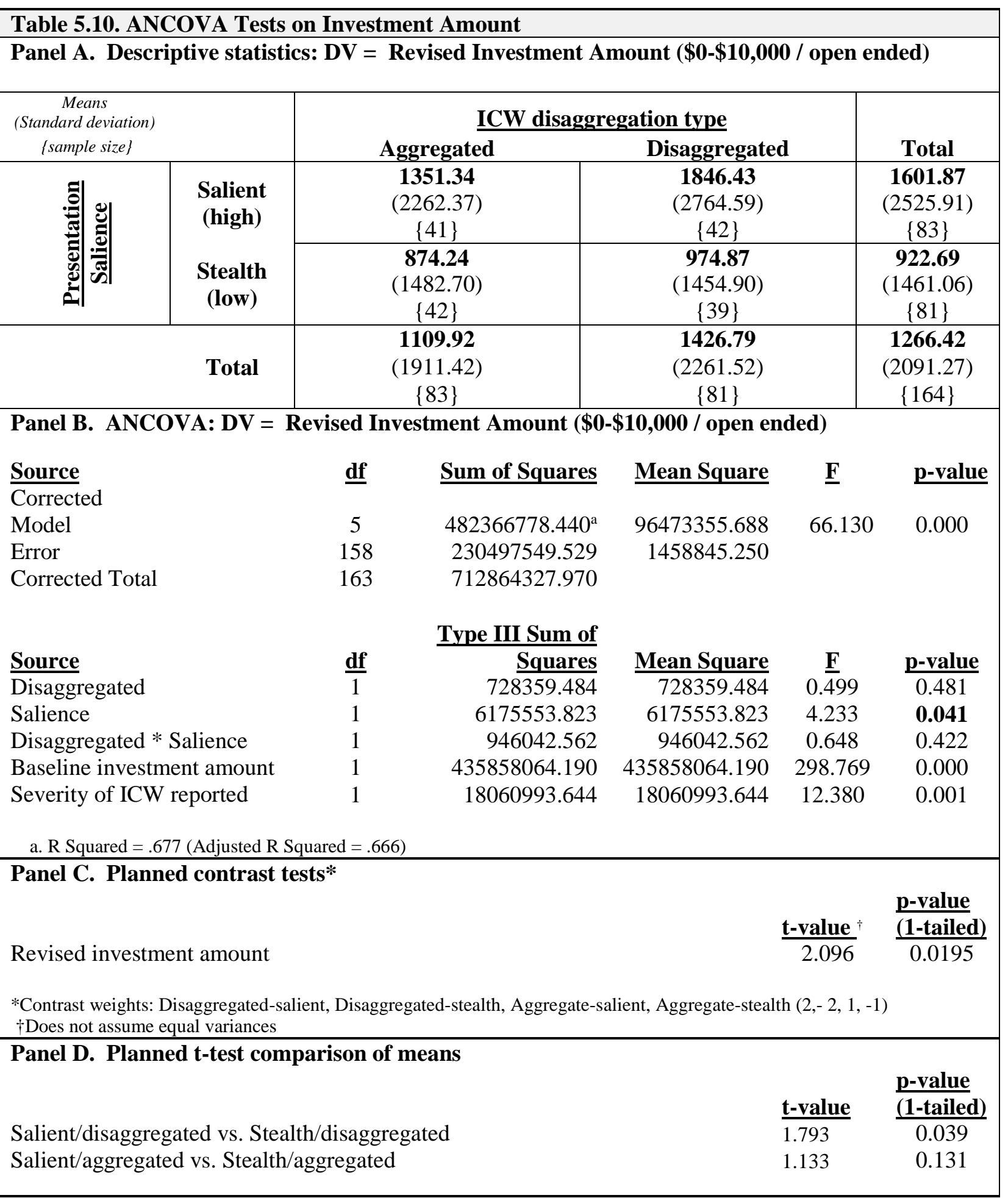


Estimated Marginal Means of Revised Investment Amount

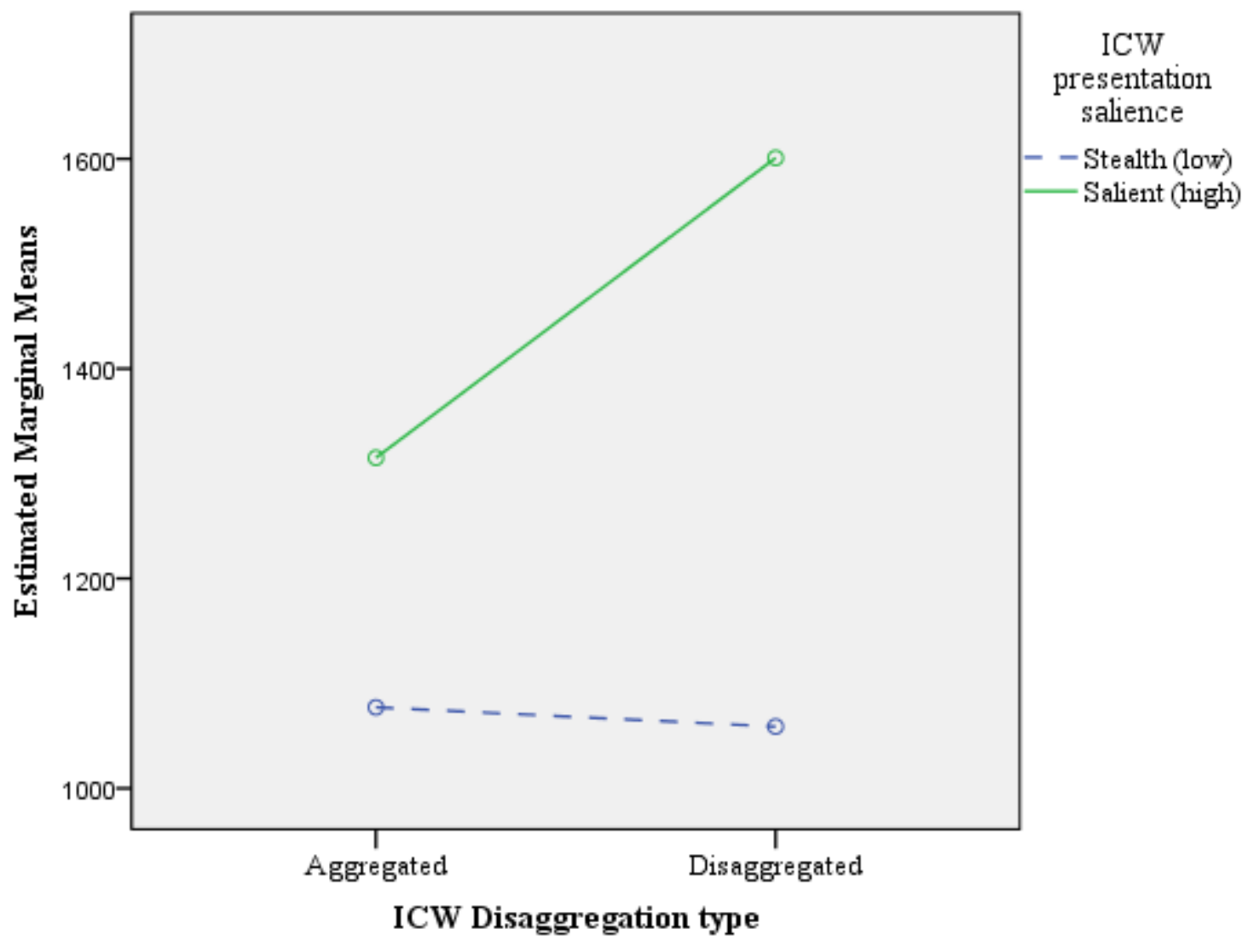

Figure 9. Means of Revised Investment Amount

\subsubsection{Summary of hypotheses tests on investing judgments}

Hypothesis 2 predicting a favorable main effect of salience on investing judgments is supported by some but not all investment judgment dependent variables. The test of the main effect of salience on the judgment of the overall impression of an investment and the decision to allocate an investment amount was significant. However, the test of the main effect of salience on the investment outlook measured by the likelihood of the stock price decrease/increase was not significant.

Hypothesis 4 predicted an interaction between salience and disaggregation of ICW diagnostic information such that the effect of salience is amplified when the disclosed ICW is 
disaggregated because investors expect disaggregated ICW to be disclosed saliently. Hypothesis 4 was supported such that there was an interactive effect of salience and disaggregation on the investment outlook measured by the likelihood of the stock price decrease/increase and on the decision to allocate an investment amount by nonprofessional investors. In contrast, there was no significant support of an interactive effect of salience and disaggregation on nonprofessional investors’ overall impression of the investment. Hypothesis 4 was not supported as it related to the impression of investment dependent variable. 


\section{ADDITIONAL ANAL YSIS}

\subsection{The Effect of Nonprofessional Investor Sophistication (Experience, Confidence, and Financial Literacy)}

Libby and Emett (2014) suggest that investing expertise and financial literacy may also work to mitigate the presentation formatting effects on investment judgments documented by Rennekamp (2012). The literature on the use of numerosity heuristics also suggests that domain knowledge and expertise should attenuate the unpacking effects of disaggregation (Pelham et al. 1994). Unlike professional investors, nonprofessional investors are less able to integrate the relation between sections of reports such as financial statements (Maines and McDaniel 2000). Therefore, it is reasonable to expect that the combined effect of presentation salience and disaggregation will be different for sophisticated and unsophisticated nonprofessional investors.

Three coarse measures of nonprofessional investor sophistication were collected in this study: investing experience, reliance on financial advisors, and financial literacy. Reliance on financial advisors likely measures investor confidence, which is expected to be related to sophistication. Financial literacy score was significantly positively correlated with years of investing experience and negatively correlated with reliance on financial advisors. However, reliance on financial advisors and investing experience are not significantly correlated. I constructed a measure of investor sophistication by combining these three variables using a twostep procedure. First, I performed a median split on all three variables and created three dummy variables. Second, I created a dichotomous sophistication variable which classified participants based on the majority classification on the original three categorical variables (2 out of 3). 
A 2 × 2 × 2 MANCOVA model (not tabulated) was used to control for the correlation between perceptions of risk of misstatement, impressions of the investment, and likelihood of price increase/decrease. Sophistication (Low=0, High=1) was added as the third factor to investigate interaction effects. Adding sophistication to the MANCOVA model improved the significance on the interaction between disaggregation and salience $(p=.062)^{24}$. This indicates that the results that were obtained previously are not due to sophistication differences. The three way interaction among the factors was also significant ( $p=.079)$, indicating that the extent to which our factors jointly affect nonprofessional investors depends on their sophistication level.

A series of $2 \times 2 \times 2$ ANCOVA models were used to obtain further insight on whether sophistication helps participants that fall prey to presentation and formatting effects of ICW disclosures. Sophistication (Low=0, High=1) was included as the third factor and interacted with the independent variables in the prior ANCOVA models for each of the four dependent variables.

Table 6.1 contains the means of risk of misstatement and the ANCOVA model that incorporates sophistication as a third factor. There was a main effect of salience that remained significant, but no interaction between salience and disaggregation was observed. Neither the main effect of sophistication nor the interaction between salience and sophistication was significant. This result indicates that sophistication does not help nonprofessional investors to mitigate the presentation format effects of salience on their perceptions of misstatement risk. There was a significant three-way interaction between salience, disaggregation, and sophistication $(p=.072)$.

\footnotetext{
${ }^{24}$ I also included investing experience, reliance on financial advisors and financial literacy as covariates and find qualitatively similar results on the interaction between salience and disaggregation $(p<.10)$.
} 
As shown in Figure 10 the patterns of the means were different for unsophisticated and sophisticated nonprofessional investors. Further planned contrast tests indicated that the predicted pattern for Hypotheses 1 and 3 holds for the higher sophistication group $(p=.020)$ but was not significant for the lower sophistication group $(p=.229)$. Unsophisticated nonprofessional investors appeared to be considering material weaknesses as more important and expect material weaknesses to be disclosed saliently.

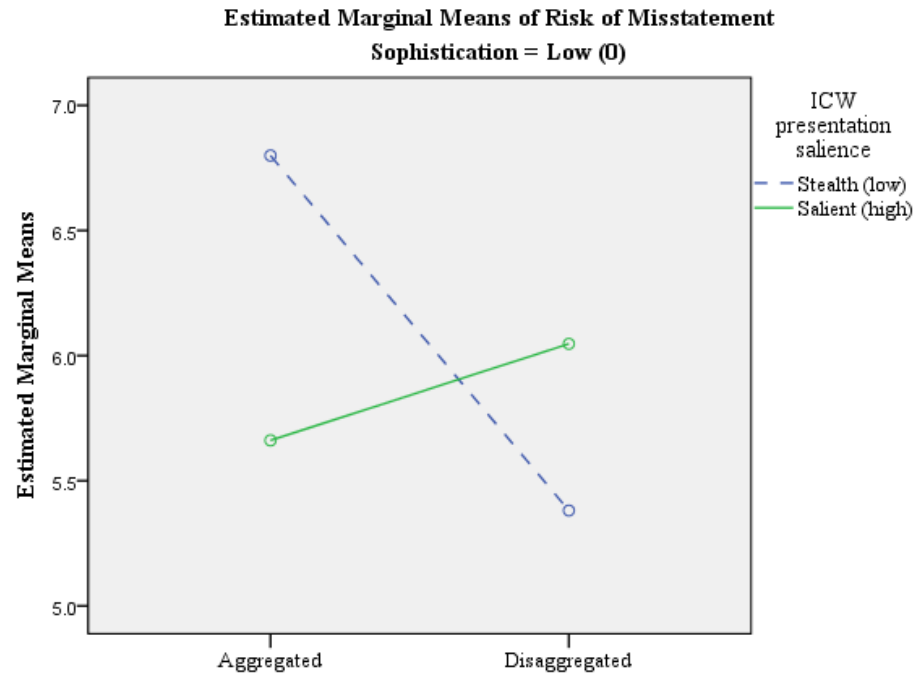

ICW Disaggregation type

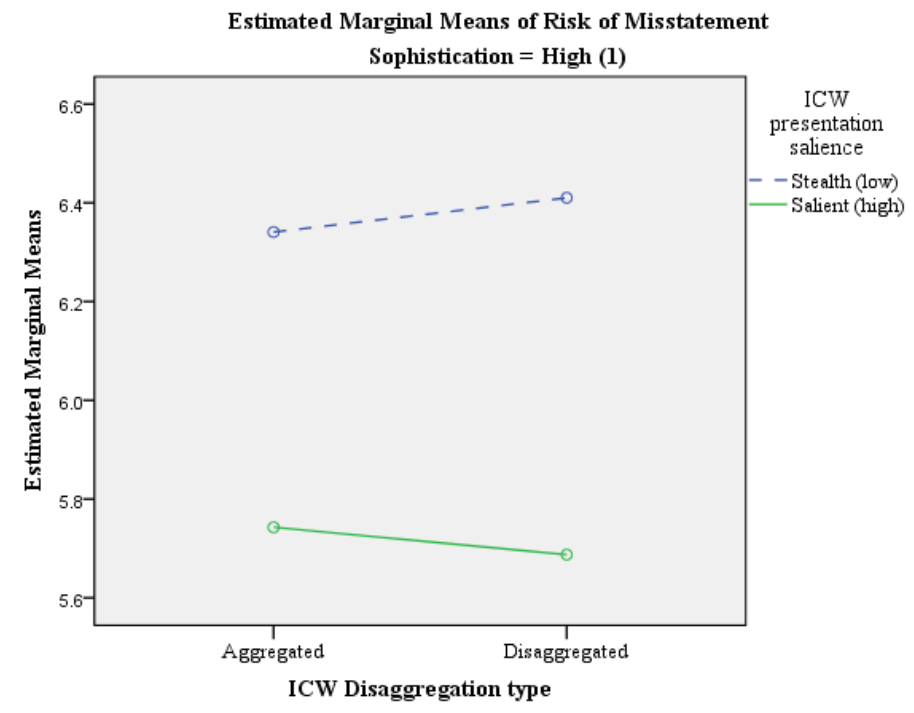

Figure 10. Means of Risk of Misstatement by Sophistication 


\begin{tabular}{|c|c|c|c|c|c|c|c|}
\hline Panel A. & Descriptive Sta & tistics: DV = Ris & of mis & isstatement (0 & Jo chance & 10-Highly & ikely) \\
\hline $\begin{array}{l}\text { Means } \\
\text { (Standard de }\end{array}$ & eviation) & $\underline{\underline{\mathrm{ICW}}}$ & & $\underline{\text { ICW }}$ & aggregati & type & \\
\hline \{sample size & & salience & & Aggregated & Disag & regated & Total \\
\hline •ฮี & & Salient (high) & & $\begin{array}{c}5.50 \\
(2.33) \\
\{18\}\end{array}$ & & $\begin{array}{l}.19 \\
.75) \\
21\}\end{array}$ & $\begin{array}{c}5.87 \\
(2.04) \\
\{39\} \\
\end{array}$ \\
\hline 氙 & $\begin{array}{c}\text { Less } \\
\text { Sophisticated }\end{array}$ & Stealth (low) & & $\begin{array}{c}\mathbf{6 . 6 8} \\
(1.46) \\
\{19\} \\
\end{array}$ & & $\begin{array}{l}.07 \\
.98) \\
15\} \\
\end{array}$ & $\begin{array}{c}5.97 \\
(1.87) \\
\{34\} \\
\end{array}$ \\
\hline 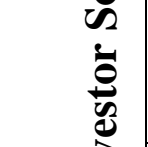 & & Total & & $\begin{array}{c}\mathbf{6 . 1 1} \\
(2.00) \\
\{37\} \\
\end{array}$ & & $\begin{array}{l}.72 \\
.91) \\
36\} \\
\end{array}$ & $\begin{array}{c}5.92 \\
(1.95) \\
\{73\} \\
\end{array}$ \\
\hline 总 & & Salient (high) & & $\begin{array}{c}\mathbf{5 . 7 4} \\
(2.16) \\
\{23\}\end{array}$ & & $\begin{array}{l}.67 \\
.65) \\
21\} \\
\end{array}$ & $\begin{array}{c}\mathbf{5 . 7 0} \\
(1.91) \\
\{44\}\end{array}$ \\
\hline ·욜 & $\begin{array}{c}\text { More } \\
\text { Sophisticated }\end{array}$ & Stealth (low) & & $\begin{array}{c}\mathbf{6 . 3 5} \\
(1.99) \\
\{23\} \\
\end{array}$ & & $\begin{array}{l}71 \\
.88) \\
24\} \\
\end{array}$ & $\begin{array}{c}\mathbf{6 . 5 3} \\
(1.92) \\
\{47\} \\
\end{array}$ \\
\hline 高 & & Total & & $\begin{array}{c}\mathbf{6 . 0 4} \\
(2.08) \\
\{46\}\end{array}$ & & $\begin{array}{l}.22 \\
.83) \\
45\}\end{array}$ & $\begin{array}{c}\mathbf{6 . 1 3} \\
(1.95) \\
\{91\}\end{array}$ \\
\hline Panel B. & ANCOVA: DV & $=$ Risk of misst & ement & t (0-No chanc & 10-Highls & likely) & \\
\hline & & & & $\underline{\text { Sum of }}$ & Mean & & \\
\hline Source & & & $\underline{\text { df }}$ & Squares & Square & $\underline{\mathbf{F}}$ & p-value \\
\hline$\overline{\text { Correctec }}$ & Model & & $\overline{9}$ & $\overline{185.442^{\mathrm{a}}}$ & $\overline{20.605}$ & $7 . \overline{3} 39$ & 0.000 \\
\hline Error & & & 154 & 432.339 & 2.807 & & \\
\hline Correctes & Total & & 163 & 617.780 & & & \\
\hline & & & & $\frac{\text { Type III }}{\underline{\text { Sum of }}}$ & $\underline{\text { Mean }}$ & & \\
\hline Source & & & df & $\underline{\text { Squares }}$ & Square & $\underline{\mathbf{F}}$ & p-value \\
\hline$\overline{\text { Disaggre }}$ & gated & & $\overline{1}$ & 2.587 & 2.587 & $0 . \overline{9} 21$ & 0.339 \\
\hline Salience & & & 1 & 7.868 & 7.868 & 2.803 & 0.096 \\
\hline Disaggre & gated * Salience & & 1 & 7.021 & 7.021 & 2.501 & 0.116 \\
\hline Sophistic & ation & & 1 & 0.209 & 0.209 & 0.075 & 0.785 \\
\hline Sophistic & ation * Disaggre & ated & 1 & 2.725 & 2.725 & 0.971 & 0.326 \\
\hline Sophistic & ation * Salience & & 1 & 1.777 & 1.777 & 0.633 & 0.428 \\
\hline Sophistic & ation * Disaggre & ated * Salience & 1 & 9.215 & 9.215 & 3.283 & 0.072 \\
\hline MD\&A & Reading Frequenc & & 1 & 14.345 & 14.345 & 5.110 & 0.025 \\
\hline Severity & of ICW reported & & 1 & 122.537 & 122.537 & 43.648 & 0.000 \\
\hline a. R Squ & ared $=.300$ (Adjustec & $\mathrm{R}$ Squared $=.259$ ) & & & & & \\
\hline Panel C & - Planned contr & ist tests by Soph & ticatic & & & t-value & $\begin{array}{l}\text { p-value } \\
\text { (1-tailed) }\end{array}$ \\
\hline Risk of $\mathrm{N}$ & Misstatement at Sc & phistication $=\mathrm{Lc}$ & $v(0)$ & & & $\overline{-0.748}$ & 0.229 \\
\hline Risk of $\mathrm{N}$ & Misstatement at Sc & phistication $=\mathrm{H}$ & h (1) & & & 2.089 & 0.020 \\
\hline
\end{tabular}


Table 6.2 contains the means of revised impression of investment and the ANCOVA model that incorporates sophistication as a third factor. There was a main effect of salience that remained significant after inclusion of sophistication in the model. Sophistication and its interaction with the other factors were all insignificant. Additional planned contrast tests indicated that nonprofessional investors with low sophistication behaved in the manner predicted in the hypotheses as it related to impression of investment $(p=.014)$ and similar to those with high sophistication ( $p=.052)$. Independent t-tests between the salient and stealth conditions were significant for the low sophistication group in both aggregated $(p=.029)$ and disaggregated conditions ( $p=.015$ ). However, independent t-tests between the salient and stealth conditions for the high sophistication group were significantly different for only the disaggregated condition ( $p=.033$ ) and not the aggregated condition $(p=.454)$. It appears that the results for the more sophisticated group provide support for Hypothesis 3 as it relates to impression of the investment. Sophistication did not appear to be mitigating the effects of presentation format on investing judgments as it relates to participants' impression of the investment in the disaggregated format. Figure 11 depicts the means of impressions of the investment for each group of sophistication level.
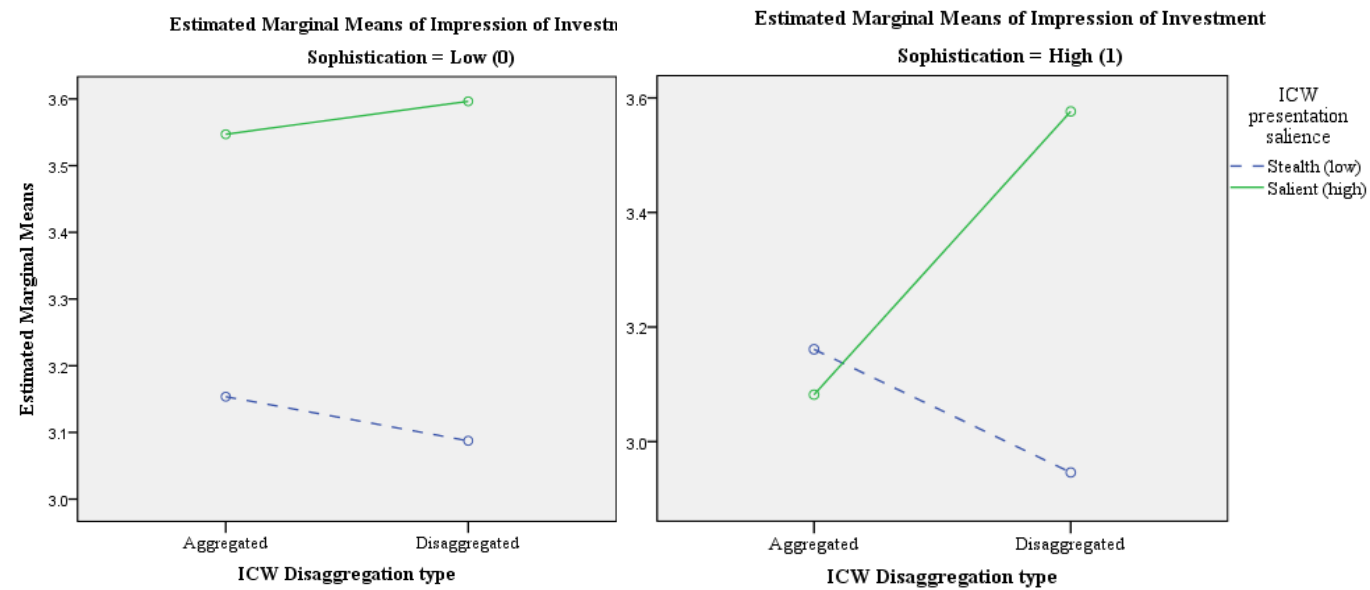

Figure 11. Means of Revised Impression of Investment by Sophistication 


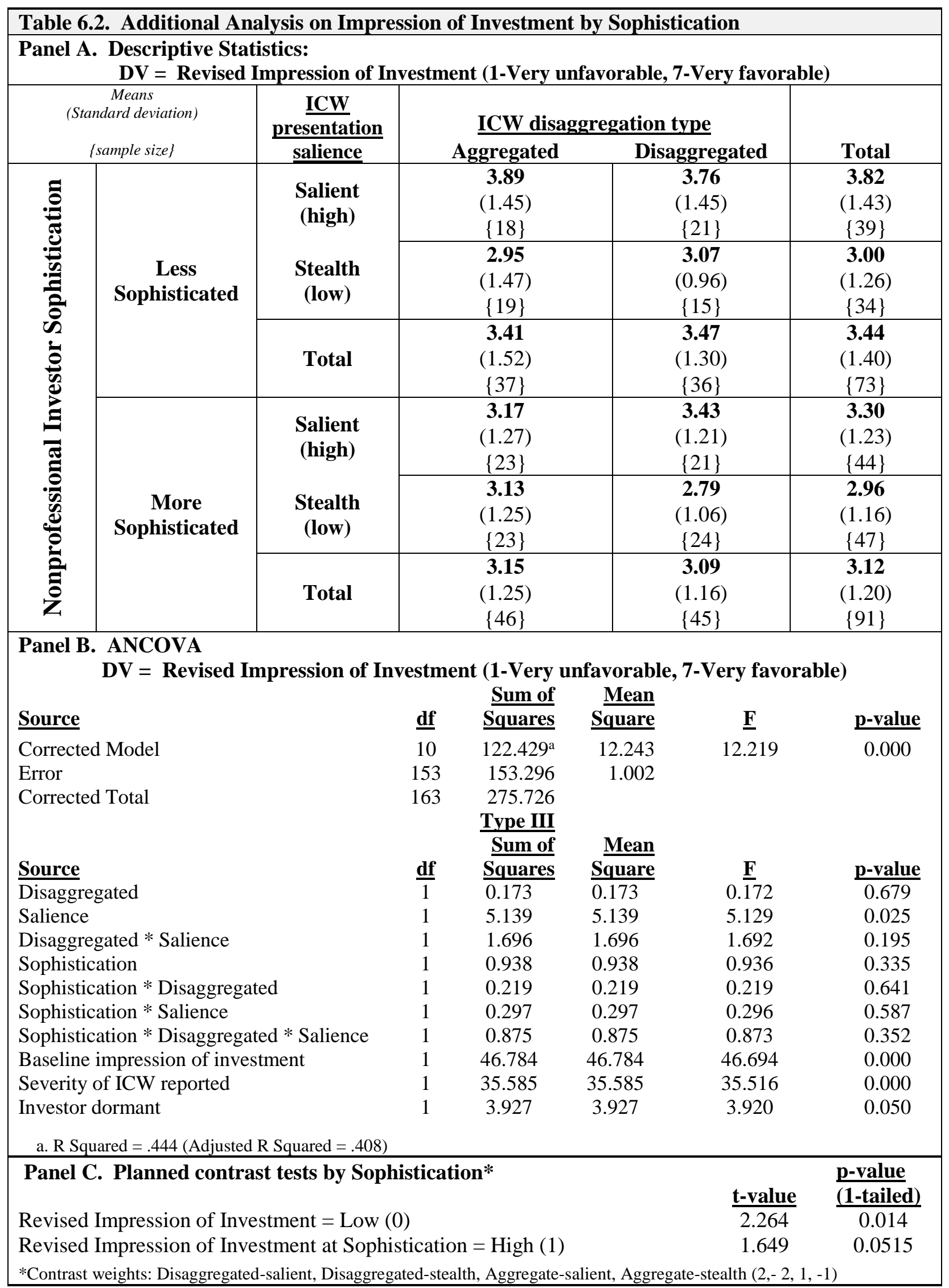


Table 6.3 contains the means of revised likelihood of stock price decrease/increase and the ANCOVA model that incorporates sophistication as a third factor. The interaction between salience and disaggregation that was observed in the original model remained significant $(p=.050)$. Additionally, there was a significant interaction between salience and sophistication. Planned contrasts test performed on both groups indicated that the predicted model was significant for participants with low sophistication but not for those with high sophistication. Further analyses using independent t-tests indicated that sophisticated investors expected an aggregated MW to be presented in a less salient format ( $p=.093$ ) but were not significantly affected (although in the predicted direction) by their expectations of having an MW disaggregated as a combination of control deficiencies to be presented saliently $(p=.204)$. As indicated in Figure 12, it appears that sophistication and presentation formats interact but in a slightly different way than initially predicted for the likelihood of stock price increase/decrease.
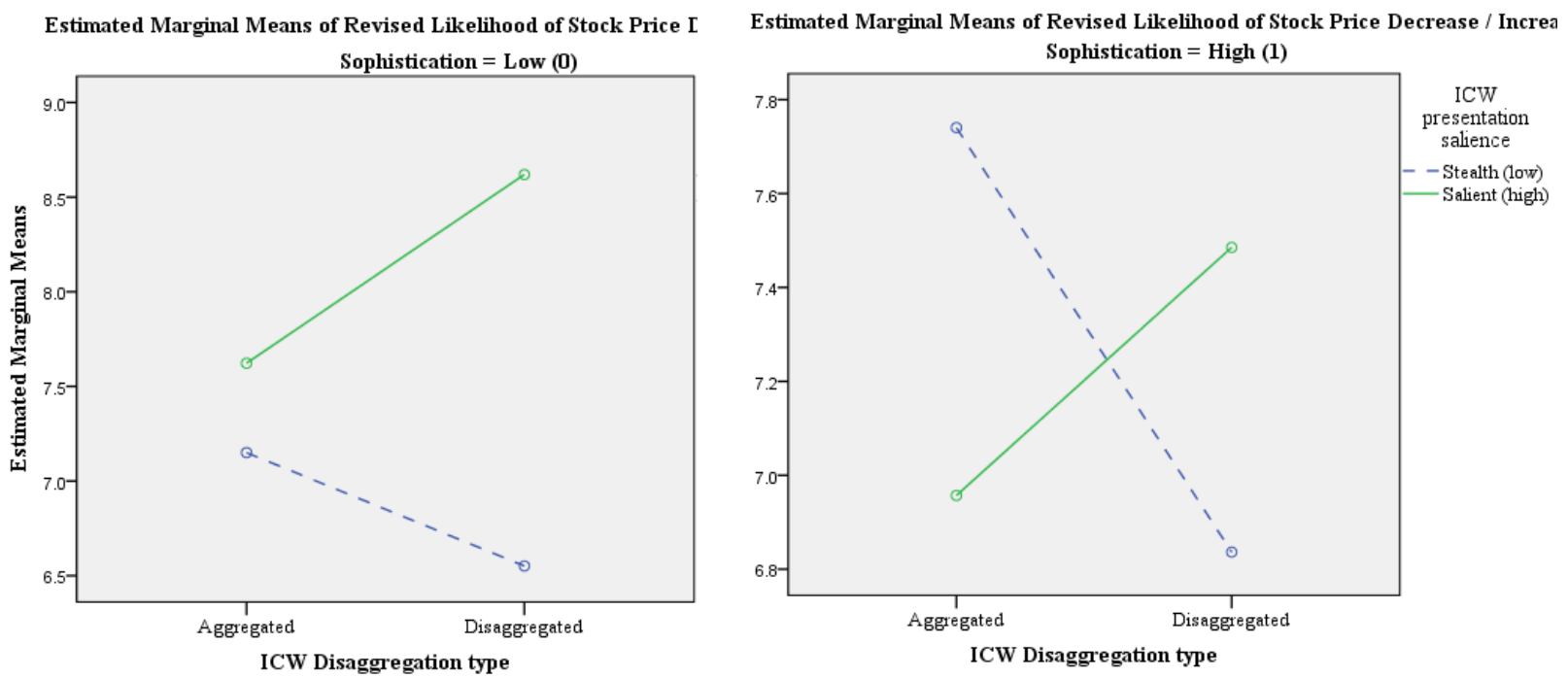

Figure 12. Means of Revised Likelihood of Stock Price Decrease/Increase by Sophistication 


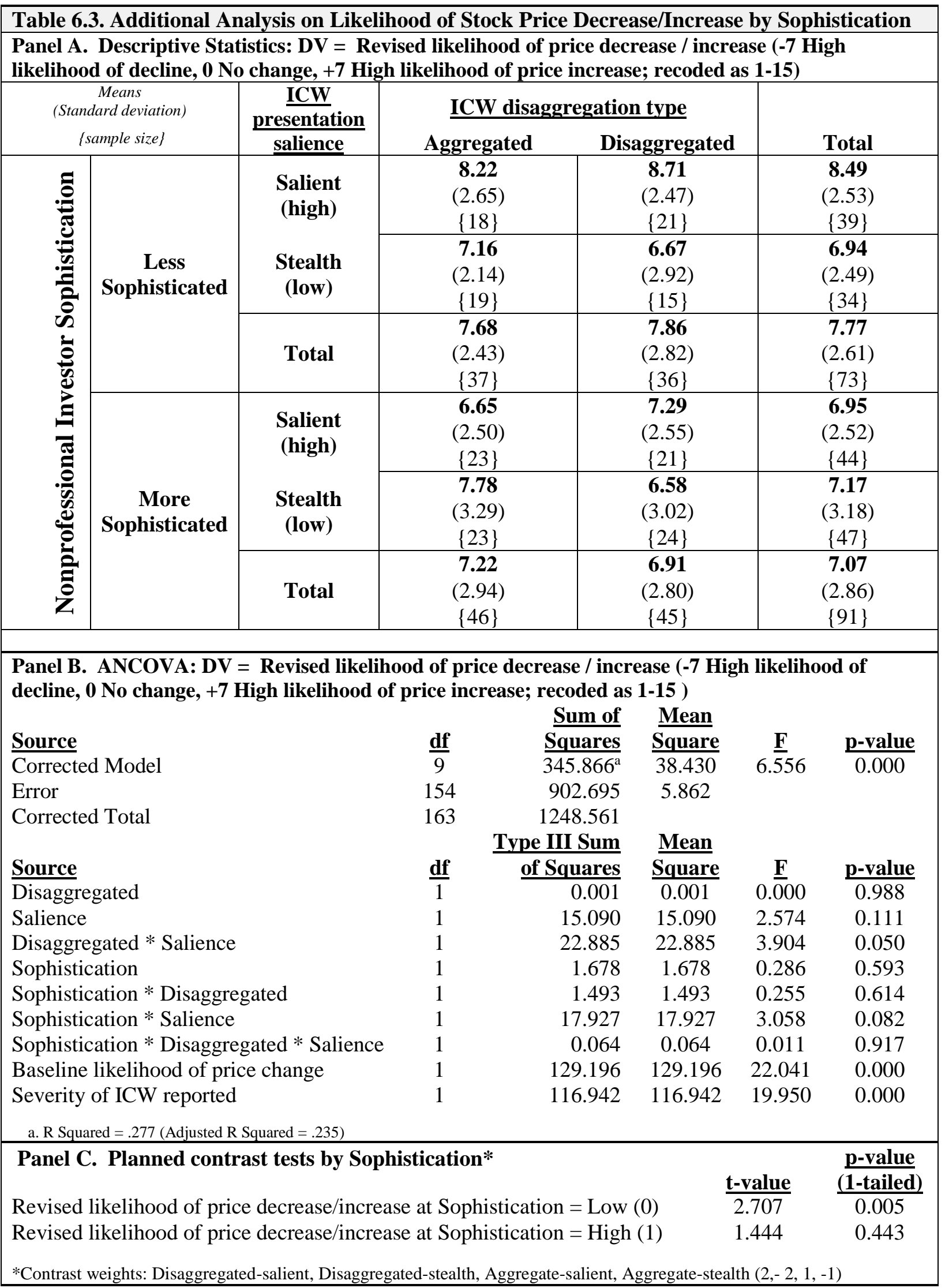


Table 6.4 contains the means assessments of revised investment amount and the ANCOVA model that incorporates sophistication as a third factor. Salience remained significant as was initially observed in the original model $(p=.039)$. There were no significant interactions between sophistication and the factors. However, planned contrast tests performed on both groups indicated that the predicted model was only significant when sophistication was low $(p=.003)$. Further analyses using independent t-tests indicated that unsophisticated nonprofessional investors were affected by salience both in the aggregated and disaggregated conditions ( $p=.017, p=.036$ respectively), but sophisticated nonprofessional investors were not affected by salience in either levels of disaggregation. This finding indicates that sophistication appears to be mitigating the effects of presentation format on investing decisions, at least in the aggregated conditions. Figure 13 displays the means of revised investment amounts by sophistication level.
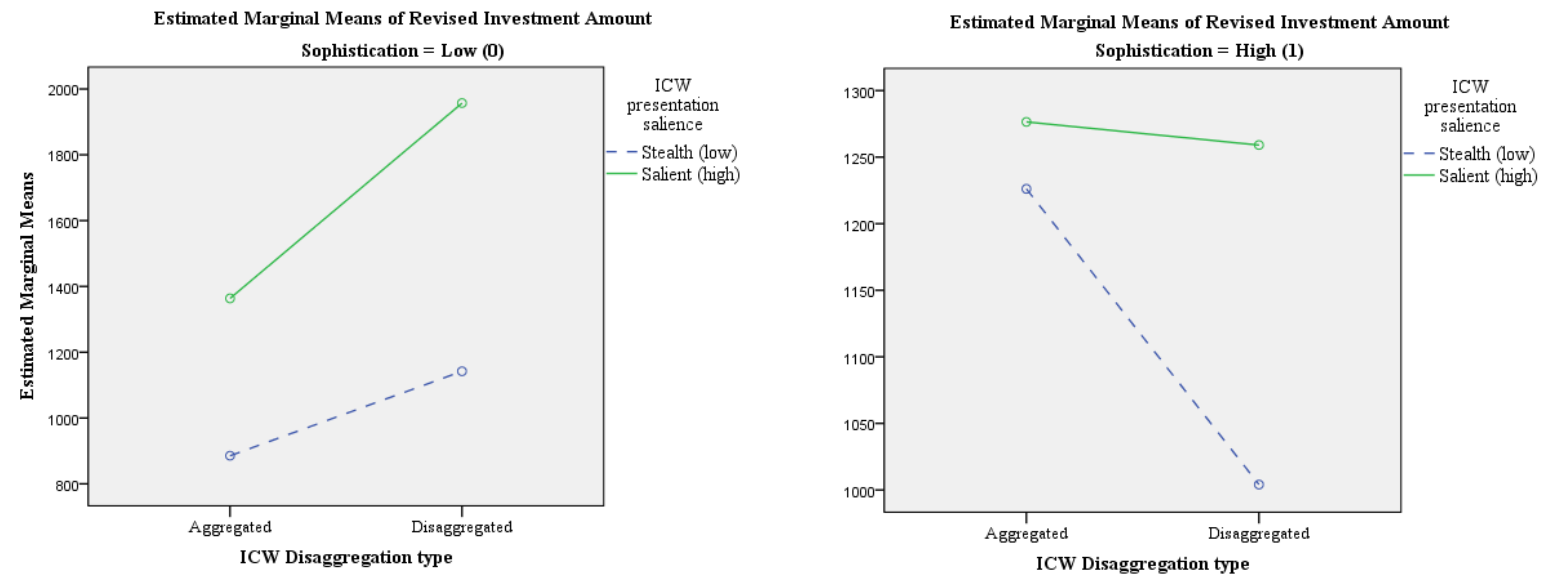

Figure 13. Means of Revised Investment Amount by Sophistication 


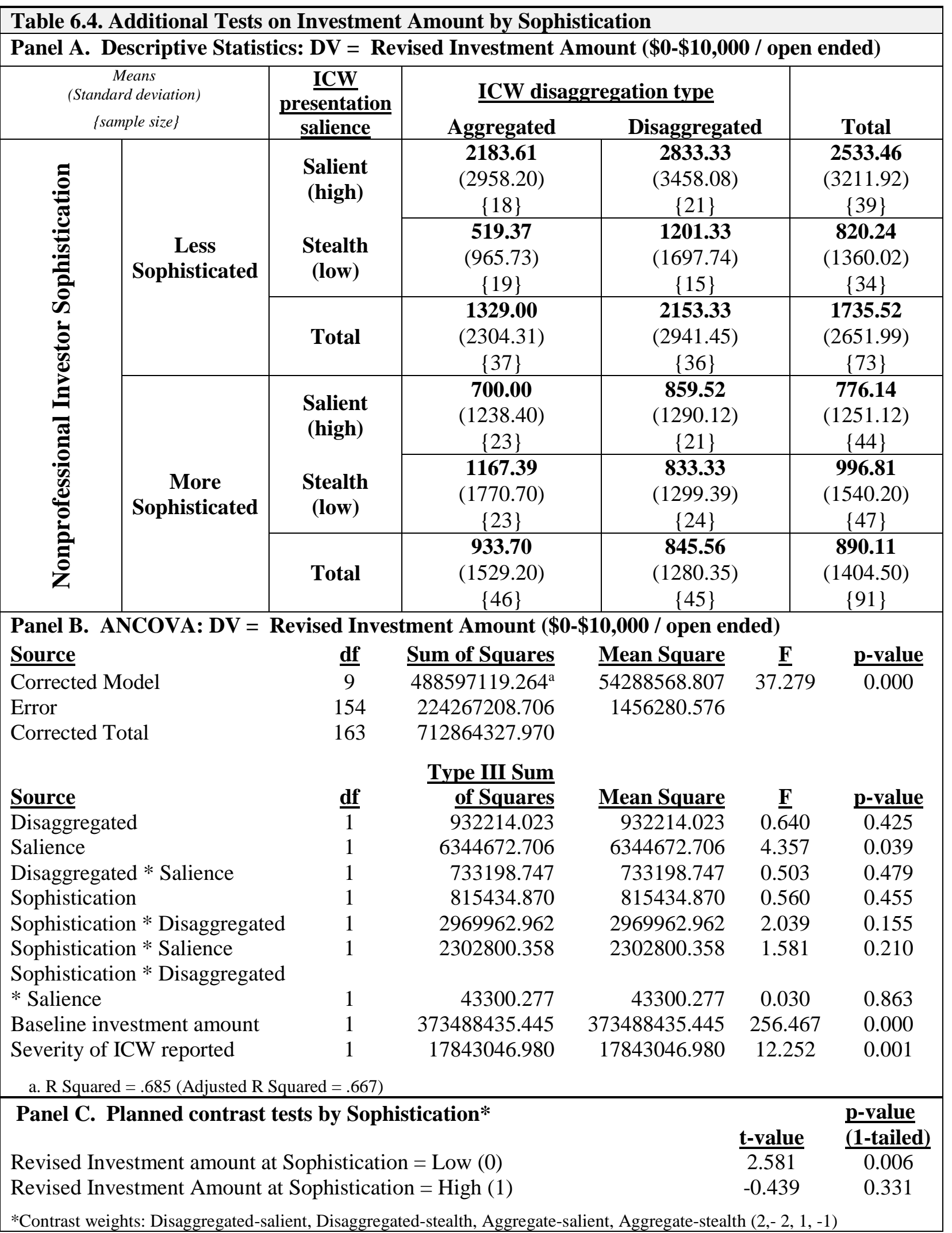




\subsection{Management Trust, Competence, and Credibility}

Management trust, competence, and credibility were collected to provide additional support on the effect of presentation salience on nonprofessional investors' impressions of management. The arguments that led to the directional hypotheses of a positive effect of processing fluency in a bad news setting relies on the assumption that report users will have positive perceptions of management's characteristics and management credibility. The predictions of an interaction between salience and disaggregation are also heavily reliant on report users’ perceptions of management trust and credibility.

I performed a series of three separate ANCOVA tests to determine whether perceptions of management trust, management competence, and management credibility were different across the experimental conditions. The results of the ANCOVA tests are presented in Table 6.5. All three models were statistically significant $(p<.05)$. The interaction between disaggregation and salience was significant in the management trustworthiness model ( $p=.076)$ and the management credibility model ( $p=.07)$, and marginally significant in the management competence model ( $p=.109)$. I performed a series of two tests for each management characteristic variable comparing the means in the salient condition with the means in the stealth condition for aggregated and disaggregated conditions separately. The results of the tests disaggregated/salient > disaggregated/stealth were significant in the predicted directions for management trustworthiness $(p=.072)$ and management credibility ( $p=.081)$, but not significant for management competence ( $p=.122)$. The means were not significantly different for the means in the aggregated conditions $(p<.10)$. 


\begin{tabular}{|c|c|c|c|c|c|}
\hline \multicolumn{6}{|c|}{ Panel A. ANCOVA: DV = Management Trustworthiness (1-Strongly disagree, 7- Strongly agree) } \\
\hline Source & $\underline{\text { df }}$ & $\underline{\text { Sum of }}$ & Mean Square & $\underline{\mathbf{F}}$ & p-value \\
\hline Corrected Model & 4 & $24.852^{\mathrm{a}}$ & 6.213 & 3.147 & 0.016 \\
\hline Error & 159 & 313.953 & 1.975 & & \\
\hline Corrected Total & 163 & 338.805 & & & \\
\hline Source & df & $\frac{\text { Type III Sum }}{\text { of Squares }}$ & Mean Square & $\mathbf{F}$ & p-value \\
\hline Disaggregated & $\overline{1}$ & 1.137 & 1.137 & $0 . \overline{576}$ & 0.449 \\
\hline Salience & 1 & 0.174 & 0.174 & 0.088 & 0.767 \\
\hline Disaggregated * Salience & 1 & 6.311 & 6.311 & 3.196 & 0.076 \\
\hline Severity of ICW reported & 1 & 18.018 & 18.018 & 9.125 & 0.003 \\
\hline \multicolumn{6}{|c|}{ Panel B. ANCOVA: DV = Management Competence (1-Strongly disagree, 7- Strongly agree) } \\
\hline Source & df & $\underline{\text { Sum of }} \underline{\text { Squares }}$ & Mean Square & $\underline{\mathbf{F}}$ & p-value \\
\hline Corrected Model & 4 & $37.456^{\mathrm{a}}$ & 9.364 & 4.734 & 0.001 \\
\hline Error & 159 & 314.513 & 1.978 & & \\
\hline Corrected Total & 163 & 351.970 & & & \\
\hline & & Type III Sum & & & \\
\hline Source & $\underline{\text { df }}$ & of Squares & Mean Square & $\underline{\mathbf{F}}$ & p-value \\
\hline$\overline{\text { Disaggregated }}$ & $\overline{1}$ & 1.953 & 1.953 & $0 . \overline{98} 7$ & 0.322 \\
\hline Salience & 1 & 0.005 & 0.005 & 0.003 & 0.959 \\
\hline Disaggregated * Salience & 1 & 5.142 & 5.142 & 2.599 & 0.109 \\
\hline Severity of ICW reported & 1 & 31.631 & 31.631 & 15.991 & 0.000 \\
\hline \multicolumn{6}{|c|}{ Panel C. ANCOVA: DV = Management Credibility (AVG of trust and competence) } \\
\hline & & Sum of & & & \\
\hline Source & df & $\overline{\text { Squares }}$ & Mean Square & $\underline{\mathbf{F}}$ & p-value \\
\hline Corrected Model & $\overline{4}$ & $30.622^{\mathrm{a}}$ & 7.656 & 4.457 & 0.002 \\
\hline Error & 159 & 273.126 & 1.718 & & \\
\hline \multirow[t]{2}{*}{ Corrected Total } & 163 & 303.748 & & & \\
\hline & & Type III Sum & & & \\
\hline Source & df & of Squares & Mean Square & $\underline{\mathbf{F}}$ & p-value \\
\hline$\overline{\text { Disaggregated }}$ & $\overline{1}$ & 1.517 & 1.517 & $0 . \overline{8} 83$ & 0.349 \\
\hline Salience & 1 & 0.060 & 0.060 & 0.035 & 0.852 \\
\hline Disaggregated * Salience & 1 & 5.711 & 5.711 & 3.325 & 0.070 \\
\hline Severity of ICW reported & 1 & 24.349 & 24.349 & 14.175 & 0.000 \\
\hline
\end{tabular}




\subsection{The Effect of Salience on Information Acquisition in IC Reports}

Additional analyses was performed to determine whether salience in IC reports improves the ability of nonprofessional investors to extract the diagnostic information disclosed. CroelProell et al. (2014) indicates that presentation salience helps nonprofessional investors to incorporate costly information into their judgments. In the ICW setting, improvement of diagnostic information access would mean that IC report users can more easily determine the type of MW disclosed, the number of MWs (CDs) disclosed, and the severity of the ICD disclosed.

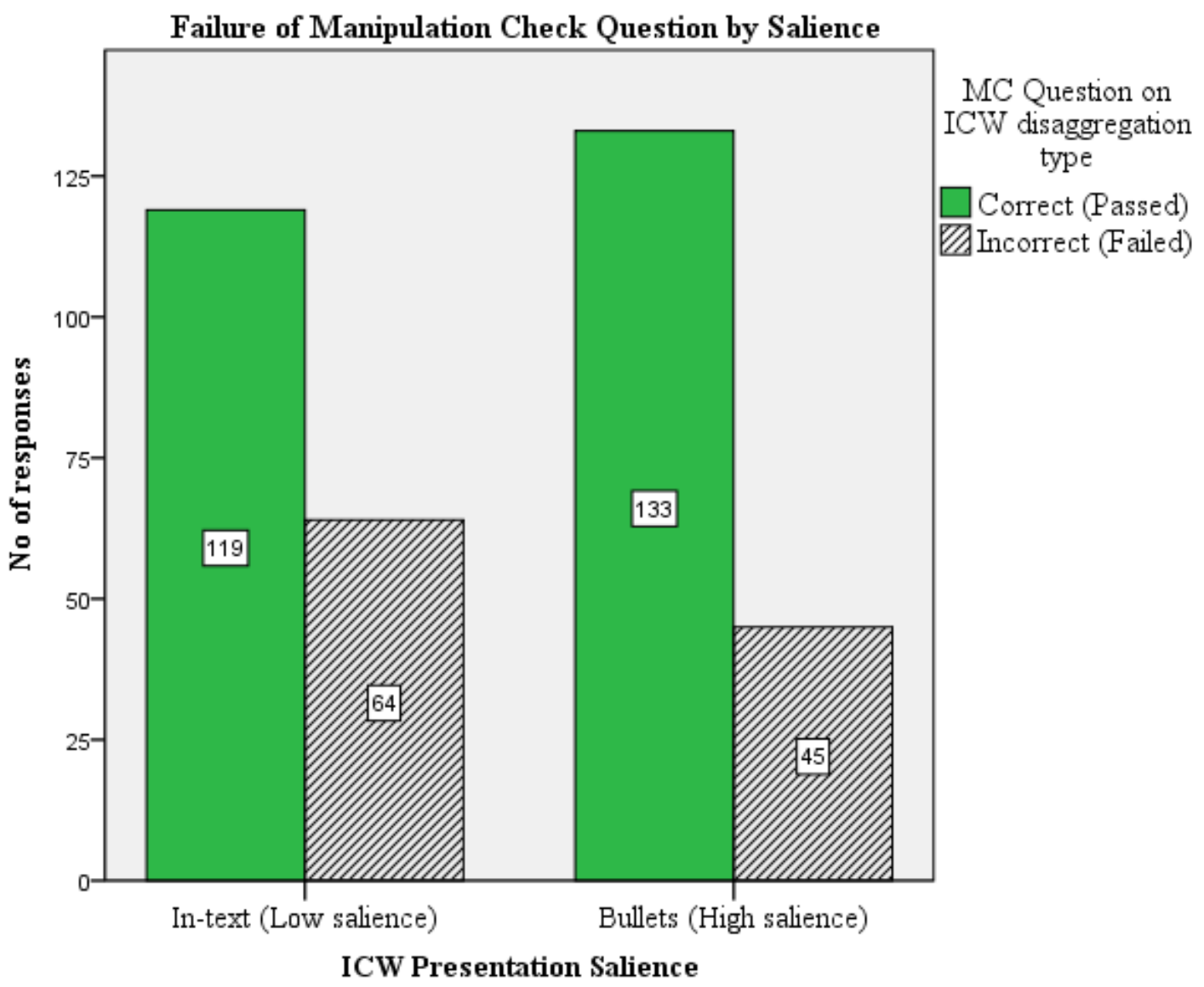

Figure 14. Performance on ICW type Manipulation Check by Salience 
Figure 14 depicts the number of participants who passed and failed the manipulation check question that related to identifying the type of ICD that was disclosed by salience levels. I investigate the proportion of manipulation failures to this question by collapsing the salient and stealth conditions. This analysis helps determine whether presentation salience helped the participants in this study to identify the type of ICW that was disclosed by increasing ICW information access in IC reports. Comparison between low salience and high salience conditions are performed using a chi-squared test. The results indicate that the high presentation salience (bulleted) condition has significantly lower proportion of manipulation failure on the ICD identification question than the low presentation salience (in-text) condition $\left(\chi^{2}=4.02, p<.05\right)$. Therefore, presentation salience may help nonprofessional investors access the diagnostic information in ICW disclosures. 


\section{DISCUSSION AND CONCLUSION}

\subsection{Summary}

Using a controlled behavioral experiment, this dissertation tested whether ICW presentation salience and ICW disaggregation differentially affect nonprofessional investor perceptions. The results indicate a dysfunctional effect of presentation salience on investing judgments in that it led to increased effects of ease of information access when combined with disaggregation of the disclosed information. This effect of presentation salience on investing judgments was amplified when the disclosed information was in an unpacked form. Specifically, when a material weakness that arises from a combination of control deficiencies is presented in a bulleted format, it was perceived more positively for investing judgments than when the same information was disclosed in an in-text format. A summary of the results of the tests of hypotheses is presented in Table 7.1.

\begin{tabular}{|l|c|c|}
\hline Table 7.1. Summary of the Results of the Hypotheses Tests \\
\hline Dependent Variable & $\begin{array}{c}\text { Test of H1 } \\
\text { Salience } \rightarrow \downarrow \text { Risk of } \\
\text { Misstatement }\end{array}$ & $\begin{array}{l}\text { Test of H3 } \\
\text { Salience } \mathbf{x} \text { Disaggregation } \\
\text { Risk of Misstatement }\end{array}$ \\
\hline Risk of Misstatement & $\begin{array}{c}\text { Supported } \\
\text { (ANCOVA) }\end{array}$ & $\begin{array}{c}\text { Not Supported } \\
\text { (ANCOVA and Planned contrast) }\end{array}$ \\
\hline \hline Dependent Variable & $\begin{array}{c}\text { Test of H2 } \\
\text { Salience } \rightarrow \uparrow \text { Investing } \\
\text { Judgments }\end{array}$ & $\begin{array}{l}\text { Test of H4 } \\
\text { Salience x Disaggregation } \\
\text { Investing Judgments }\end{array}$ \\
\hline Impression of investment & $\begin{array}{c}\text { Supported } \\
\text { (ANCOVA) }\end{array}$ & $\begin{array}{c}\text { Supported } \\
\text { (Planned contrast) }\end{array}$ \\
\hline $\begin{array}{l}\text { Likelihood of price } \\
\text { decline/increase }\end{array}$ & $\begin{array}{c}\text { Not Supported } \\
\text { (ANCOVA) }\end{array}$ & $\begin{array}{c}\text { Supported } \\
\text { (ANCOVA and Planned contrast) }\end{array}$ \\
\hline Investment amount & $\begin{array}{c}\text { Supported } \\
\text { (ANCOVA) }\end{array}$ & $\begin{array}{c}\text { Supported } \\
\text { (Planned contrast) }\end{array}$ \\
\hline
\end{tabular}


This effect of salience on investing judgments was predicted and found to be more severe for nonprofessional investors when displayed in a disaggregated format. Nonprofessional investors likely overweight an ICW that is in a disaggregated format because presentation of such material requires cognitive effort to combine heuristic cues and has lower processing fluency. Thus, in this experiment processing fluency was decreased by disaggregation. The second manipulation also affected processing fluency; decreasing it in a stealth (in-text) presentation format and increasing it in the bulleted (salient) presentation format. Additionally, as predicted, an ICW that arises from a combination of control deficiencies was attributed to higher management competence and trust when it is disclosed saliently than when it is disclosed in a stealth manner.

Similar directional hypotheses were posited regarding the effect of salience and disaggregation on nonprofessional investors' assessments of misstatement risk. The results indicated that salience was associated with lower assessments of risk of misstatement. Interestingly, the planned contrast tests and additional results indicated that nonprofessional investors expected "material” weaknesses to be displayed in a salient format and rewarded management that disclosed the aggregated ICW saliently. The result indicates that the task of analyzing risk of misstatement leads nonprofessional investors to form expectations of the material weakness to be saliently disclosed only when that disclosure is of the aggregated type (MW). The result was consistent with predictions of attribution theory.

\subsection{Contribution}

The dissertation shows that increased ease of access to information and disaggregation may not always be as desirable as the SEC and the FASB's financial statement presentation framework advocates. Although the information contained in the ICW disclosure is expected to 
be negative, increased ease of access to such negative information appears to mitigate the negative response to ICW disclosures. This positive effect of presentation salience to negative information disclosure may not be desirable since it results purely from the presentation of the information.

The findings of this study contribute to the literature on ICW disclosures, nonprofessional investor behavior, and presentation formats of nonfinancial information disclosures. Academics who currently study the effects of ICW disclosures on investing and risk of material misstatement do not control for either ICW disaggregation or ICW presentation salience. The results provide support for the inclusion of these variables and opens avenues to future archival research that replicates studies in the ICW literature. The stream of literature on presentation formats of corporate nonfinancial information is also informed regarding the positive effect of presentation salience in a bad news setting of the disclosure of internal control weaknesses. Specifically, presentation salience of bad news leads to a more positive interpretation of the information cue regardless of the valence of the information. This result is contrary to the findings of Rennekamp (2012), which is related to the investing effects of processing fluency on earnings announcements (negative effect for bad news and positive for good news).

The study also contributes to practice since the different ICW formats that are tested in this dissertation are present in the 10-K reports that are currently being filed with the SEC. Management currently using one of the ICW formats to prepare ICW disclosures can be made aware of the unintended consequences of the format used to prepare the ICW disclosure section on nonprofessional investor behavior. Management may want to use a salient presentation format particularly when it has material weaknesses that arise from a combination of control deficiencies. The findings indicate that nonprofessional investors respond significantly less 
negatively in their investing judgments and perceived management as more credible when a material weakness that arises from a combination of control deficiencies is disclosed using a salient (bulleted) format than when it is disclosed using a stealth (in-text) format.

The findings also have implications to the design used for the auditor's standard report and some of the proposed changes to the level of detail that need to be included by the auditor. Specifically, the format and structure of the presentation of detailed significant audit findings and disaggregation of audit procedures may lead investors to weight that information differently. Standard setters may need to consider a stylistic standard to avoid unintended differences in weighting information that is contained in an update that expands the standard audit report.

\subsection{Limitations}

The study has several limitations that are acknowledged here. First, the operationalization of disaggregation assumes that a material weakness is equivalent to the three control deficiencies. To alleviate this concern, the multiple control deficiencies that were disclosed in the disaggregate setting were also briefly included in the description of the material weakness. Additionally, the results observed for the specific type of material weakness may not hold true for other types of material weaknesses. Second, due to the methods used by the panel survey service and participants’ limited attention, a high rate of manipulation failure in this study was observed. The high failure rate indicates that some participants may not even read the entire internal control report as documented in Arnold et al. (2011). The findings of this dissertation are therefore limited to the group of nonprofessional investors that are not fatigued by some of the longer IC reports that may have a higher non-diagnostic information to diagnostic information ratio. Third, the use of a survey panel combined with an online instrument sacrificed some experimental control that would have otherwise been available in a laboratory 
setting. Participants may therefore have been distracted, interrupted, or performed other tasks while completing the study.

\subsection{Future Research}

Professional and nonprofessional investors have differences in their approaches to information access, information processing, and information evaluation (Elliott 2006; Maines and McDaniel 2000; Anderson 1988; Frederickson and Miller 2004). Professional investors use a directed search strategy and have mental models of the cues that help identify firm performance (Frederickson and Miller 2004; Bouwman et al. 1987). Unlike professional investors, nonprofessional investors use a sequential search strategy to access information, rely on the use of heuristics, and have ill-defined valuation models (Maines and McDaniel 2000).

Studies comparing the performance of professional and nonprofessional investors indicate that professional investors are better able to extract information such as ICW information from annual reports, use valuation models instead of simple heuristics, are better able to recognize the relation between different sections of a financial report, and are less influenced by unaudited information (Elliott 2006; Arnold et al. 2011; Maines and McDaniel 2000; Frederickson and Miller 2004; Hirst and Hopkins 1998; Dilla et al. 2012). However, professional investors are also susceptible to location effects of information (Hirst and Hopkins 1998; Dilla et al. 2012).

Nonprofessional and professional investors are likely to process ICW information differently because, unlike professionals, nonprofessional investors access information sequentially and have ill-defined valuation models (Maines and McDaniel 2000). However, while professional investors are able to access information in a directed manner and possess better defined mental valuation models, they have been documented to be susceptible to 
formatting effects (Hirst and Hopkins 1998). Therefore, it is unclear how these investor groups will differ in their reaction to alternative ICW presentation formats. Future research can investigate whether the favorable effects of ICW presentation salience and the interaction documented in this study will hold for the professional investor group. 


\section{REFERENCES}

Adelberg, Arthur Harris. 1979. Narrative disclosures contained in financial reports: Means of communication or manipulation? Accounting and Business Research 9, (35): 179-90.

Ahmed, Anwer S., Mary Lea McAnally, Stephanie Rasmussen, and Connie D. Weaver. 2010. How costly is the sarbanes oxley act? Evidence on the effects of the act on corporate profitability. Journal of Corporate Finance 16, (3) (6): 352-69.

Alter, A. L., and D. M. Oppenheimer. 2009. Uniting the tribes of fluency to form a metacognitive nation. Personality and Social Psychology Review: An Official Journal of the Society for Personality and Social Psychology, Inc 13, (3) (Aug): 219-35.

Anderson, Matthew J. 1988. A comparative analysis of information search and evaluation behavior of professional and non-professional financial analysts. Accounting, Organizations and Society 13, (5): 431-46.

Arnold, Vicky, Jean C. Bedard, Jillian R. Phillips, and Steve G. Sutton. 2011. Do section 404 disclosures affect investors' perceptions of information systems reliability and stock price predictions? International Journal of Accounting Information Systems 12, (4): 243-58.

Asare, Stephen K., Brian C. Fitzgerald, Lynford E. Graham, Jennifer R. Joe, Eric M. Negangard, and Christopher J. Wolfe. 2012. Auditors' internal control over financial reporting decisions: Analysis, synthesis, and research directions. Auditing: A Journal of Practice \& Theory 32, (sp1): 131-66.

Asare, Stephen K., and Arnold M. Wright. 2012. The effect of change in the reporting threshold and type of control deficiency on equity analysts' evaluation of the reliability of future financial statements. Auditing 31, (2) (May 2012): 1-17.

Ashbaugh-Skaife, Hollis, Daniel W. Collins, and Ryan Lafond. 2009. The effect of SOX internal control deficiencies on firm risk and cost of equity. Journal of Accounting Research 47, (1): $1-43$.

Bedard, Jean C., and Lynford Graham. 2011. Detection and severity classifications of sarbanesoxley section 404 internal control deficiencies. The Accounting Review 86, (3): 825-55.

Bedard, Jean C., Rani Hoitash, Udi Hoitash, and Kimberly Westermann. 2012a. Material weakness remediation and earnings quality: A detailed examination by type of control deficiency. Auditing 31, (1) (Feb 2012): 57-78. 
Bedard, Jean C., Steve G. Sutton, Vicky Arnold, and Jillian R. Phillips. 2012b. Another piece of the "Expectations gap": What do investors know about auditor involvement with information in the annual report? Current Issues in Auditing 6, (1): A17-30.

Beneish, Messod Daniel, Mary Brooke Billings, and Leslie D. Hodder. 2008. Internal control weaknesses and information uncertainty. The Accounting Review 83, (3): 665-703.

Bloomfield, Robert J. 2002. The “incomplete revelation hypothesis” and financial reporting. Accounting Horizons 16, (3): 233-43.

Boritz, J. Efrim, Louise Hayes, and Jee-Hae Lim. 2012. What do Auditor's reports on internal control tell us about IT control weaknesses in financial reporting systems? Paper presented at CAAA Annual Conference, .

Bouwman, Marinus J., Patricia A. Frishkoff, and Paul Frishkoff. 1987. How do financial analysts make decisions? A process model of the investment screening decision. Accounting, Organizations and Society 12, (1): 1-29.

Bowen, Robert M., Angela K. Davis, and Dawn A. Matsumoto. 2005. Emphasis on pro forma versus GAAP earnings in quarterly press releases: Determinants, SEC intervention, and market reactions. The Accounting Review 80, (4): 1011-38.

Brink, Alisa Gabrielle. 2013. Nonprofessional investors’ perceptions of corporate governance factors. Journal of Accounting, Ethics \& Public Policy 14, (2): 289-330.

Browning, ES, Pui-Wing Tam, and Aaron Lucchetti. 1999. As stock funds lag, investors are taking control of their money. Wall Street Journal: Al.

Clor-Proell, Shana M., Chad A. Proell, and Terry D. Warfield. 2014. The effects of presentation salience and measurement subjectivity on nonprofessional investors' fair value judgments. Contemporary Accounting Research 31, (1): 45-66.

Coates IV, John C., and Suraj Srinivasan. 2014. SOX after ten years: A multidisciplinary review. Accounting Horizons, Forthcoming.

Cohen, Jeffrey R., Colleen Hayes, Ganesh Krishnamoorthy, Gary S. Monroe, and Arnold M. Wright. 2012. The effectiveness of SOX regulation: An interview study of corporate directors. Behavioral Research in Accounting 25, (1): 61-87.

Cohen, Jeffrey, Ganesh Krishnamoorthy, and Arnie Wright. 2010. Corporate governance in the Post-Sarbanes-Oxley era: Auditors’ experiences*. Contemporary Accounting Research 27, (3): 751-86.

Costello, Anna M., and Regina Wittenberg Moerman. 2010. The impact of financial reporting quality on debt contracting: Evidence from internal control weakness reports. Rochester, Rochester: Social Science Research Network. 
Courtis, John K. 1998. Annual report readability variability: Tests of the obfuscation hypothesis. Accounting, Auditing \& Accountability Journal 11, (4): 459.

Courtis, John K. 2004. Corporate report obfuscation: Artefact or phenomenon? The British Accounting Review 36, (3) (9): 291-312.

Crabtree, Aaron, PhD, and John J. Maher PhD. 2012. Credit ratings, cost of debt, and internal control disclosures: A comparison of SOX 302 and SOX 404. Journal of Applied Business Research 28, (5) (Sep/Oct 2012): 885-902.

Dhaliwal, Dan, Chris Hogan, Robert Trezevant, and Michael Wilkins. 2011. Internal control disclosures, monitoring, and the cost of debt. The Accounting Review 86, (4): 1131-56.

Dilla, William N., Diane J. Janvrin, and Cynthia Jeffrey. 2012. The impact of graphical displays of pro forma earnings information on professional and nonprofessional investors' earnings judgments. Behavioral Research in Accounting 25, (1): 37-60.

Doidge, Craig, G. Andrew Karolyi, and Rene M. Stulz. 2010. Why do foreign firms leave US equity markets? The Journal of Finance 65, (4): 1507-53.

Elliott, W. Brooke. 2006. Are investors influenced by pro forma emphasis and reconciliations in earnings announcements? The Accounting Review 81, (1): 113-33.

Engel, Ellen, Rachel M. Hayes, and Xue Wang. 2007. The Sarbanes-Oxley act and firms' goingprivate decisions. Journal of Accounting and Economics 44, (1-2) (9): 116-45.

Evans, James D. 1996. Straightforward statistics for the behavioral sciences Brooks/Cole.

Farkas, Maia, and Uday S. Murthy. 2014. Nonprofessional investors' perceptions of the incremental value of continuous auditing and continuous controls monitoring: An experimental investigation. International Journal of Accounting Information Systems 15, (2): 102-21.

Files, Rebecca, Edward P. Swanson, and Senyo Tse. 2009. Stealth disclosure of accounting restatements. The Accounting Review 84, (5): 1495-520.

Foster, Benjamin P., William Ornstein, and Trimbak Shastri. 2007. Audit costs, material weaknesses under SOX section 404. Managerial Auditing Journal 22, (7): 661.

Frederickson, James R., and Jeffrey S. Miller. 2004. The effects of pro forma earnings disclosures on analysts' and nonprofessional investors' equity valuation judgments. The Accounting Review 79, (3): 667-86.

Gao, Feng, Joanna Shuang Wu, and Jerold Zimmerman. 2009. Unintended consequences of granting small firms exemptions from securities regulation: Evidence from the SarbanesOxley act. Journal of Accounting Research 47, (2): 459-506. 
Ge, Weili, and Sarah McVay. 2005. The disclosure of material weaknesses in internal control after the sarbanes-oxley act. Accounting Horizons 19, (3) (Sep 2005): 137-58.

Ghosh, Aloke, and Robert Pawlewicz. 2009. The impact of regulation on auditor fees: Evidence from the sarbanes-oxley act. Auditing: A Journal of Practice \& Theory 28, (2): 171-97.

Gupta, Parveen P., and Nandkumar Nayar. 2007. Information content of control deficiency disclosures under the sarbanes-oxley act: An empirical investigation. International Journal of Disclosure and Governance 4, (1) (Feb 2007): 3-23.

Haase, Richard F., and Michael V. Ellis. 1987. Multivariate analysis of variance. Journal of Counseling Psychology 34, (4): 404.

Hammersley, Jacqueline S., Linda A. Myers, and Catherine Shakespeare. 2008. Market reactions to the disclosure of internal control weaknesses and to the characteristics of those weaknesses under section 302 of the sarbanes oxley act of 2002. Review of Accounting Studies 13, (1) (Mar 2008): 141-65.

Hammersley, Jacqueline S., Linda A. Myers, and Jian Zhou. 2012. The failure to remediate previously disclosed material weaknesses in internal controls. Auditing 31, (2) (May 2012): 73-111.

Hirst, D. Eric, and Patrick E. Hopkins. 1998. Comprehensive income reporting and analysts' valuation judgments. Journal of Accounting Research: 47-75.

Hoag, Matthew L., and Carl W. Hollingsworth. 2011. An intertemporal analysis of audit fees and section 404 material weaknesses. Auditing 30, (2) (May 2011): 173-200.

Hochberg, Yael V., Paola Sapienza, and ANNETTE VISSING-JØRGENSEN. 2009. A lobbying approach to evaluating the Sarbanes-Oxley act of 2002. Journal of Accounting Research 47, (2): 519-83.

Hogarth, Robin M. 1987. Judgement and choice: The psychology of decision .John Wiley \& Sons.

Holder, Anthony D., Khondkar E. Karim, and Ashok Robin. 2013. Was dodd-frank justified in exempting small firms from section 404b compliance? Accounting Horizons 27, (1) (Mar 2013): 1.

Hostak, Peter, Thomas Lys, Yong George Yang, and Emre Carr. 2013. An examination of the impact of the Sarbanes-Oxley act on the attractiveness of US capital markets for foreign firms. Review of Accounting Studies 18, (2): 522-59.

Huberty, Carl J., and John D. Morris. 1989. Multivariate analysis versus multiple univariate analyses. Psychological Bulletin 105, (2): 302. 
Iliev, Peter. 2010. The effect of SOX section 404: Costs, earnings quality, and stock prices. The Journal of Finance 65, (3): 1163-96.

Jonas, G., A. Rosenberg, M. Doss, and G. Cihak. 2005. Section 404 reporting on internal control: Our early experience. Moody's Investors Service.

Kamar, Ehud, Pinar Karaca-Mandic, and Eric Talley. 2009. Going-private decisions and the sarbanes-oxley act of 2002: A cross-country analysis. Journal of Law, Economics, and Organization 25, (1): 107-33.

Kaplan, Steven E., Janet A. Samuels, and Jeffrey Cohen. 2015. An examination of the effect of CEO social ties and CEO reputation on nonprofessional investors' say-on-pay judgments. Journal of Business Ethics 126, (1): 103-17.

Keane, Matthew J., Randal J. Elder, and Susan M. Albring. 2012. The effect of the type and number of internal control weaknesses and their remediation on audit fees. Review of Accounting \& Finance 11, (4): 377-99.

Kim, Jeong-Bon, Byron Y. Song, and Liandong Zhang. 2011. Internal control weakness and bank loan contracting: Evidence from SOX section 404 disclosures. The Accounting Review 86, (4): 1157-88.

Kinney Jr, William R., Roger D. Martin, and Marcy L. Shepardson. 2013. Reflections on a decade of SOX 404 (b) audit production and alternatives. Accounting Horizons 27, (4): 799813.

Klamm, Bonnie K., Kevin W. Kobelsky, and Marcia Weidenmier Watson. 2012. Determinants of the persistence of internal control weaknesses. Accounting Horizons 26, (2) (Jun 2012): 307-33.

Klamm, Bonnie K., and Marcia Weidenmier Watson. 2009. SOX 404 reported internal control weaknesses: A test of COSO framework components and information technology. Journal of Information Systems 23, (2) (Fall 2009): 1-23.

Krishnan, Jagan, Dasaratha Rama, and Yinghong Zhang. 2008a. Costs to comply with SOX section 404. Auditing 27, (1) (May 2008): 169-86.

. 2008b. Costs to comply with SOX section 404. Auditing: A Journal of Practice \& Theory 27, (1): 169-86.

Li, Feng. 2008. Annual report readability, current earnings, and earnings persistence. Journal of Accounting \& Economics 45, (2/3) (Aug 2008): 221.

Libby, Robert, and Scott A. Emett. 2014. Earnings presentation effects on manager reporting choices and investor decisions. Accounting and Business Research 44, (4): 410-38. 
Maines, Laureen A., and Linda S. McDaniel. 2000. Effects of comprehensive-income characteristics on nonprofessional investors' judgments: The role of financial-statement presentation format. The Accounting Review 75, (2): 179-207.

Merkl-Davies, Doris M., and Niamh M. Brennan. 2007. Discretionary disclosure strategies in corporate narratives: Incremental information or impression management? Journal of Accounting Literature 26, : 116-94.

Miller, Brian P. 2010. The effects of reporting complexity on small and large investor trading. Rochester, Rochester: Social Science Research Network.

Munsif, Vishal, K. Raghunandan, Dasaratha V. Rama, and Meghna Singhvi. 2011. Audit fees after remediation of internal control weaknesses. Accounting Horizons 25, (1) (Mar 2011): $87-105$.

Nisbett, Richard E., Henry Zukier, and Ronald E. Lemley. 1981. The dilution effect: Nondiagnostic information weakens the implications of diagnostic information. Cognitive Psychology 13, (2): 248-77.

Parker, LD. 1982. Corporate annual reporting: A mass communication perspective. Accounting and Business Research 12, (48): 279-86.

Payne, John W. 1982. Contingent decision behavior. Psychological Bulletin 92, (2): 382.

Pelham, Brett W., Tin T. Sumarta, and Laura Myaskovsky. 1994. The easy path from many to much: The numerosity heuristic. Cognitive Psychology 26, (2): 103-33.

Public Company Accounting Oversight Board (PCAOB). 2007. An audit of internal control over financial reporting that is integrated with an audit of financial statements. Vol. PCAOB Release No. 2007-005A. Washington, DC: Public Company Accounting Oversight Board (PCAOB).

R. Mithu Dey, and Mary W. Sullivan. 2012. Was dodd-frank justified in granting internal control audit exemption to small firms? Managerial Auditing Journal 27, (7): 666-92.

Raghunandan, K., and Dasaratha V. Rama. 2006. SOX section 404 material weakness disclosures and audit fees. Auditing 25, (1) (May 2006): 99-114.

Redden, Joseph P., and Shane Frederick. 2011. Unpacking unpacking: Greater detail can reduce perceived likelihood. Journal of Experimental Psychology: General 140, (2): 159.

Rennekamp, Kristina. 2012. Processing fluency and investors' reactions to disclosure readability. Journal of Accounting Research 50, (5): 1319-54. 
Rice, Sarah C., and David P. Weber. 2012. How effective is internal control reporting under SOX 404? Determinants of the (non-) disclosure of existing material weaknesses. Journal of Accounting Research 50, (3): 811-43.

Rice, Sarah, David Weber, and Biyu Wu. 2013. Does SOX 404 have teeth? Consequences of the failure to report existing internal control weaknesses. Consequences of the Failure to Report Existing Internal Control Weaknesses (March 1, 2013).

Rose, Jacob M., Carolyn Strand Norman, and Anna M. Rose. 2010. Perceptions of investment risk associated with material control weakness pervasiveness and disclosure detail. The Accounting Review 85, (5) (Sep 2010): 1787-807.

Schneider, Arnold, Audrey A. Gramling, Dana R. Hermanson, and Zhongxia (Shelly) Ye. 2009. A review of academic literature on internal control reporting under SOX. Journal of Accounting Literature 28, : 1-46.

Securities and Exchange Commission (SEC). 2003. Final rule: Management's reports on internal control over financial reporting and certification of disclosure in exchange act periodic reports. Retrieved July 24, : 2008.

1998. A plain english handbook: How to create clear SEC disclosure. SEC Office of Investor Education and Assistance. Retrieved from the SEC's Website: Http://www.Sec.gov/pdf/handbook.Pdf.

Shah, Anuj K., and Daniel M. Oppenheimer. 2011. Grouping information for judgments. Journal of Experimental Psychology: General 140, (1): 1.

- 2008. Heuristics made easy: An effort-reduction framework. Psychological Bulletin 134, (2): 207.

. 2007. Easy does it: The role of fluency in cue weighting. Judgment and Decision Making 2, (6): 371-9.

Shepardson, Marcy L., and Jr Kinney William R. 2011. Do control effectiveness disclosures require SOX 404(b) internal control audits? A natural experiment with small U.S. public companies. Journal of Accounting Research 49, (2) (May 2011): 413-48.

Simon, Herbert A. 1990. Invariants of human behavior. Annual Review of Psychology 41, (1): 120.

Stone, Gerard, and Lee D. Parker. 2013. Developing the flesch reading ease formula for the contemporary accounting communications landscape. Qualitative Research in Accounting and Management 10, (1): 31-59.

Tabachnick, Barbara G., and Linda S. Fidell. 2001. Using multivariate statistics. 
Tackett, James A., Fran Wolf, and Gregory A. Claypool. 2006. Internal control under sarbanesoxley: A critical examination. Managerial Auditing Journal 21, (3): 317-23.

Tan, Hun-Tong, Elaine Wang, and Bo Zhou. 2013. How does readability influence investors' judgments? Consistency of benchmark performance matters. Consistency of Benchmark Performance Matters (July 8, 2013).

Tversky, Amos, and Derek J. Koehler. 1994. Support theory: A nonextensional representation of subjective probability. Psychological Review 101, (4): 547.

Tversky, A., and D. Kahneman. 1974. Judgment under uncertainty: Heuristics and biases. Science (New York, N.Y.) 185, (4157) (Sep 27): 1124-31.

US House of Representatives. 2012. Jumpstart our business startups act. public law 112-106 [HR 3606].

2010. Dodd-frank wall street reform and consumer protection act. public law 111-203 [HR 4173].

—. 2002. The sarbanes-oxley act of 2002. public law 107-204 [HR 3763].

Van Boven, Leaf, and Nicholas Epley. 2003. The unpacking effect in evaluative judgments: When the whole is less than the sum of its parts. Journal of Experimental Social Psychology 39, (3) (5): 263-9.

Van Rooij, Maarten, Annamaria Lusardi, and Rob Alessie. 2011. Financial literacy and stock market participation. Journal of Financial Economics 101, (2): 449-72.

Warne, Russell T. 2014. A primer on multivariate analysis of variance (MANOVA) for behavioral scientists. Practical Assessment, Research \& Evaluation 19, (17): 1-10.

You, Haifeng, and Xiao-jun Zhang. 2009. Financial reporting complexity and investor underreaction to 10-K information. Review of Accounting Studies 14, (4): 559-86.

Zhang, Ivy Xiying. 2007. Economic consequences of the Sarbanes-Oxley act of 2002. Journal of Accounting and Economics 44, (1-2) (9): 74-115. 
APPENDICES 


\section{Appendix A: Experimental Instrument}

\section{SCREENING QUESTIONS}

Have you bought or sold individual stocks (not including mutual funds) within the past 2 years?

$\begin{array}{cc}\text { Yes } & \text { No } \\ 0 & 0\end{array}$

Have you bought or sold stocks or other securities as part of your profession (e.g. broker, analyst, financial advisor etc.)?

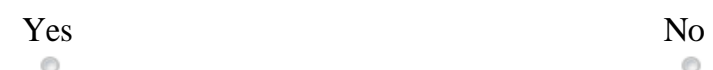

What type of device are you using to complete this survey?
Laptop / Desktop
Tablet
Mobile device / Smartphone

\section{INSTRUCTIONS}

Thank you for your participation in this research study. The purpose of this study is to obtain information about how investors make judgments and decisions. You will be asked to assume the role of an investor throughout the study. You will read information regarding a publicly traded company and respond to questions as a potential investor in this company. The information provided is intended to be representative rather than complete. Please be sure to base your opinions and perceptions only on the information provided in this case. There are no right or wrong answers. Carefully read all information provided before responding to the questions. Please refrain from pressing the "BACK" button as you are not allowed to go back to a previous screen.

Please note that you are only allowed to take this study once without any interruption. Your participation in the study is completely voluntary. You may discontinue participation in this study at any time. Your responses are confidential and no identifying information will be used.

The person in charge of this research study is Amanuel Tadesse, the Principal Investigator. However, other research staff may be involved and can act on behalf of the person in charge. This research is considered minimal risk. The risks from participating in this study are not more than would be encountered in everyday life. Your participation in this study will help advance the body of knowledge regarding investors' judgments. Please do NOT discuss the study with your friends, co-workers, or others who may also participate in this study since doing so may invalidate the results of this research.

This study, titled “Disclosures and Investing Decisions,” is an approved IRB study \#Pro00018003. If you have any questions or concerns about this study, please contact Amanuel Tadesse at 813-974-7721. If you have questions about your rights as a participant in this study, general questions, or have complaints, concerns or issues you want to discuss with someone outside the research staff, call the Division of Research Integrity and Compliance at the University of South Florida at 813-974-5638.

Please check the box below if you agree to participate in this study.

I agree to participate in this study 


\section{TASK DESCRIPTION}

You are asked to assume the role of a potential investor throughout the study. You will receive information about a small publicly traded company, ANZ Technologies. You will read and evaluate company information such as the financial statements, management's report on internal controls, and key ratio statistics for this company. Based on the information provided in the case, you will be asked to provide your perceptions and investing judgments regarding the company.

\section{COMPANY INFORMATION}

ANZ Technologies Corp (NYSE MKT: ANZT) provides electronic contract manufacturing services to advanced technology companies in the United States. It specializes in the custom manufacture of complex circuit cards and system-level assemblies for use in various products, such as military and aerospace systems, medical devices, industrial equipment, and transportation products. It is also involved in the testing and detection of counterfeit electronic parts, as well as component risk mitigation and advanced failure analysis.

\section{INDUSTRY}

The electronic semiconductor equipment market is very competitive and market demand is very volatile. Although last year saw contractions in this market, global revenues are expected to grow 4-6\% over the next year.

\section{INTERNAL CONTROLS}

Management is required by law to assess internal controls in the organization and annually report on the effectiveness of the controls over financial reporting. Internal controls are expected to provide reasonable assurance that an organization's financial statements are free of material misstatements.

\section{MATERIAL WEAKNESSES}

A material weakness is a control deficiency, or a combination of control deficiencies, in internal control over financial reporting such that there is a reasonable possibility that a material misstatement of the annual or interim financial statements will not be prevented or detected on a timely basis.

As defined above, a material weakness can either be:

- one control deficiency that is severe enough to pose the risk of material misstatement in the financial statements, or

- a combination of multiple control deficiencies that are not severe individually but when considered in aggregate pose the risk of material misstatement in the financial statements

Please note that control deficiencies are normally considered the least severe form of deficiencies in internal control and are not required to be disclosed to the public unless they rise to the severity level of a material weakness.

In the following page, please examine ANZ's provided information and respond to the questions provided. 
ANZ Technologies Corp. (NYSE MKT: ANZT)

Close price $\$ \mathbf{2 . 0 2}$

Key statistics and ratios

2014

\begin{tabular}{lll} 
& ANZT & Industry Average \\
\hline Earnings Per Share (EPS) & $\$ 0.21$ & $\$ 0.18$ \\
Price to Earnings (P/E) & 9.62 & 10.50 \\
Return on Equity (ROE) & $2.64 \%$ & $2.55 \%$ \\
Net profit margin & $2.32 \%$ & $2.30 \%$ \\
Current Ratio & 1.78 & 1.80
\end{tabular}

\section{ANZ Technologies Corporation Annual Report Form 10-K filing}

Part II, Item 8, Financial Statements and Supplementary Data

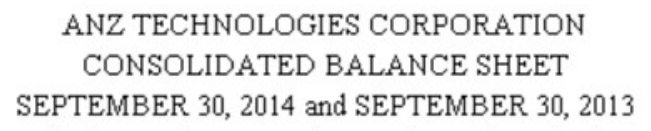

(in thousands, except share and per share data)

\begin{tabular}{|c|c|c|c|c|}
\hline & \multicolumn{2}{|c|}{$\begin{array}{r}\text { September 30, } \\
2014 \\
\end{array}$} & \multicolumn{2}{|c|}{$\begin{array}{r}\text { September } 30 \text {, } \\
2013 \\
\end{array}$} \\
\hline \multicolumn{5}{|l|}{ ASSETS } \\
\hline Current assets & $\$$ & 42,318 & $\$$ & 41,213 \\
\hline Noncurrent assets & & 45,414 & & 44,607 \\
\hline Total assets & $\$$ & 87,732 & $\$$ & 85,820 \\
\hline \multicolumn{5}{|l|}{$\begin{array}{l}\text { LIABILITIES AND STOCKHOLDERS' } \\
\text { EQUITY }\end{array}$} \\
\hline Current liabilities & & 23,687 & & 23,921 \\
\hline Long-term debt & & 21,192 & & 21,213 \\
\hline Total liabilities & & 44,879 & & 45,134 \\
\hline \multicolumn{5}{|l|}{ STOCKHOLDERS' EQUITY } \\
\hline Common stock, $\$ 0.01$ par value: & & 108 & & 108 \\
\hline Additional paid-in capital & & 40,660 & & 40,660 \\
\hline Retained Earnings & & 3,670 & & 1,353 \\
\hline Treasury stock, at cost: $1,015,458$ shares & & $(1,585)$ & & $(1,435)$ \\
\hline Total stockholders' equity & & 42,853 & & 40,686 \\
\hline Total liabilities and stockholders' equity & $\$$ & 87,732 & $\$$ & 85,820 \\
\hline
\end{tabular}




\section{ANZ TECHNOLOGIES CORPORATION}

CONSOLIDATED INCOME STATEMENT

YEARS ENDED SEPTEMBER 30, 2014 and SEPTEMBER 30, 2013

(in thousands)

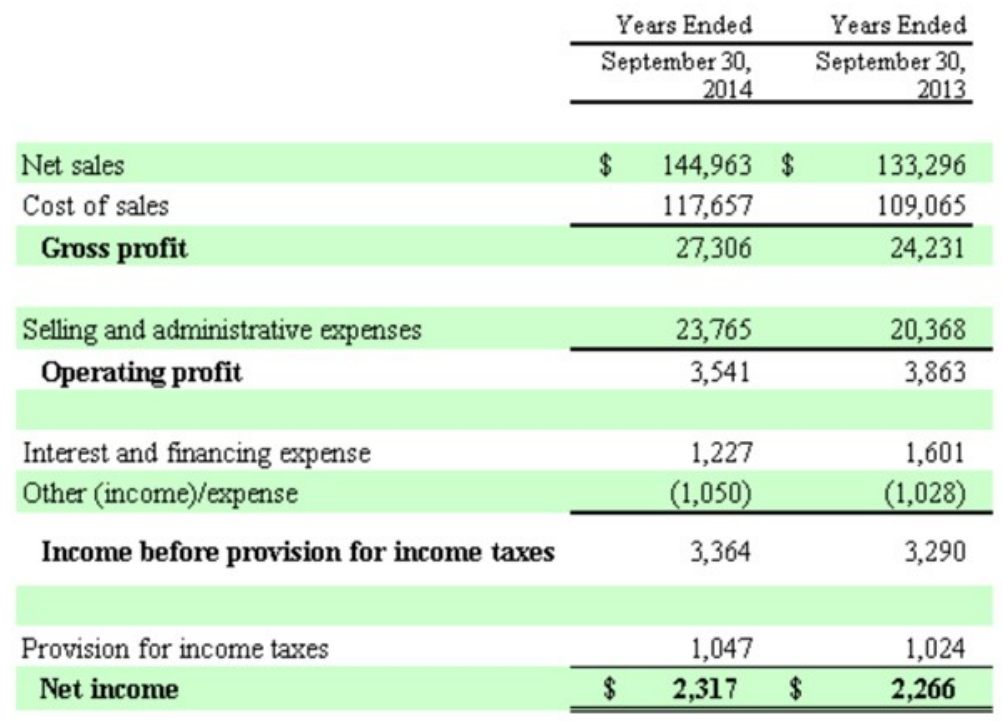

Please assume that this information was disclosed to the public today.

1. What is your overall impression of ANZ as an investment?

Very

Unfavorable

1

○

2

2

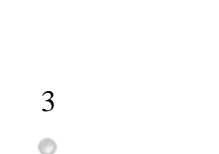

4

$\odot$
Very

Favorable

7

○

2. Assume that you recently inherited $\$ 10,000$ from a distant relative and you wanted to invest it in stocks; how much of $\$ 10,000$ would you invest in ANZ's stock?

Please enter your investment ( 0 - 10,000):

3. What is the likelihood of a moderate stock price change (1-10\%) in ANZ's stock within the next year?

Highest likelihood of decline

$\begin{array}{ccccccc}-7 & -6 & -5 & -4 & -3 & -2 & -1 \\ 0 & 0 & 0 & 0 & 0 & 0 & 0\end{array}$

No change 0

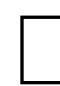




\section{MANIPULATIONS - Disaggregated Conditions}

(Please note that this page is not displayed on the actual survey instrument)

\section{Disaggregated (multiple control deficiencies) - Salient (bulleted)}

A material weakness is a control deficiency, or combination of control deficiencies, that results in more than a remote likelihood that a material misstatement of the annual or interim financial statements will not be prevented or detected. Management identified three control deficiencies which, in the aggregate, constitute a material weakness in the Company's internal control over financial reporting as of September 30, 2014. The control deficiencies include:

- ineffective controls to ensure the timely issuance of invoice adjustments

- ineffective controls over the initiation of customer master records and contracts to ensure consistent billing of periodic charges

- incompatible duties were not segregated within the billing function

Although these control deficiencies are not material individually, in aggregate, their combination could result in a material misstatement of sales and accounts receivable in the Company's interim or annual consolidated financial statements that would not be prevented or detected in a timely manner. Therefore, management has concluded that the Company did not maintain effective internal control over financial reporting as of September 30, 2014.

\section{Disaggregated (multiple control deficiencies) - Stealth (in-text)}

A material weakness is a control deficiency, or combination of control deficiencies, that results in more than a remote likelihood that a material misstatement of the annual or interim financial statements will not be prevented or detected. Management identified three control deficiencies which, in the aggregate, constitute a material weakness in the Company's internal control over financial reporting as of September 30, 2014. Specifically, the control deficiencies include ineffective controls to ensure the timely issuance of invoice adjustments, ineffective controls over the initiation of customer master records and contracts to ensure consistent billing of periodic charges, and incompatible duties that were not segregated within the billing function.

Although these control deficiencies are not material individually, in aggregate, their combination could result in a material misstatement of sales and accounts receivable in the Company's interim or annual consolidated financial statements that would not be prevented or detected in a timely manner. Therefore, management concluded that the Company did not maintain effective internal control over financial reporting as of September 30, 2014. 


\section{MANIPULATIONS - Aggregated Conditions}

(Please note that this page is not displayed on the actual survey instrument)

\section{Aggregated (single material weakness) - Salient (bulleted)}

A material weakness is a control deficiency, or combination of control deficiencies, that results in more than a remote likelihood that a material misstatement of the annual or interim financial statements will not be prevented or detected. Management identified one material weakness in the Company's internal control over financial reporting as of September 30, 2014. The material weakness is:

- The Company did not maintain effective segregation and controls over billing and invoice adjustment processes to ensure accuracy and validity of receivables.

This material weakness could result in a material misstatement of sales and accounts receivable in the Company's interim or annual consolidated financial statements that would not be prevented or detected in a timely manner. Therefore, management has concluded that the Company did not maintain effective internal control over financial reporting as of September 30, 2014.

\section{Aggregated (single material weakness) - Stealth (in-text)}

A material weakness is a control deficiency, or combination of control deficiencies, that results in more than a remote likelihood that a material misstatement of the annual or interim financial statements will not be prevented or detected. Management identified one material weakness in the Company's internal control over financial reporting as of September 30, 2014. Specifically, the material weakness is that the Company did not maintain effective segregation and controls over billing and invoice adjustment processes to ensure accuracy and validity of receivables.

This material weakness could result in a material misstatement of sales and accounts receivable in the Company's interim or annual consolidated financial statements that would not be prevented or detected in a timely manner. Therefore, management has concluded that the Company did not maintain effective internal control over financial reporting as of September 30, 2014. 


\section{EXAMPLE - Disaggregated - Salient Condition}

(Please note that this title is not displayed on the actual survey instrument)

Part II, Item 9A, Controls and Procedures;

\section{Management's Report on Internal Control over Financial Reporting}

Management is responsible for establishing and maintaining adequate internal control over financial reporting, as such term is defined in Exchange Act Rule 13a-15(f). The Company's internal control over financial reporting is a process designed to provide reasonable assurance regarding the reliability of financial reporting and the preparation of financial statements for external purposes in accordance with generally accepted accounting principles in the United States of America. Because of its inherent limitations, internal control over financial reporting may not prevent or detect misstatements.

Our management, with the participation of our Chief Executive Officer and Chief Financial Officer, has evaluated the effectiveness of the Company's internal control over financial reporting using the criteria described in Internal Control - Integrated Framework issued by the Committee of Sponsoring Organizations of the Treadway Commission (“COSO”).

A material weakness is a control deficiency, or combination of control deficiencies, that results in more than a remote likelihood that a material misstatement of the annual or interim financial statements will not be prevented or detected. Management identified three control deficiencies which, in the aggregate, constitute a material weakness in the Company's internal control over financial reporting as of September 30, 2014. The control deficiencies include:

- ineffective controls to ensure the timely issuance of invoice adjustments

- ineffective controls over the initiation of customer master records and contracts to ensure consistent billing of periodic charges

- incompatible duties were not segregated within the billing function

Although these control deficiencies are not material individually, in aggregate, their combination could result in a material misstatement of sales and accounts receivable in the Company's interim or annual consolidated financial statements that would not be prevented or detected in a timely manner. Therefore, management has concluded that the Company did not maintain effective internal control over financial reporting as of September 30, 2014.

This annual report does not include an attestation report of our registered public accounting firm regarding internal control over financial reporting. Management's report was not subject to attestation by our registered public accounting firm pursuant to the Dodd-Frank Wall Street Reform and Consumer Protection Act, which permits us to provide only management's report in this annual report. 
1. Considering the above internal control disclosure, what is your overall impression of ANZ as an investment? Recall that your impression of the investment prior to viewing this disclosure was "[\#\# from baseline assessment]"?

Very

Unfavorable

1

2

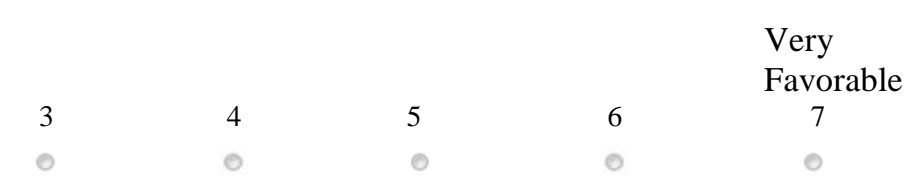

2. Assume that you recently inherited $\$ 10,000$ from a distant relative and you wanted to invest it in stocks; how much of \$10,000 would you invest in ANZ's stock? Recall that you were willing to invest "[\#\# from baseline assessment]" in ANZ's stock prior to viewing this disclosure.

Please enter your investment ( 0 - 10,000):

3. What is the likelihood of a moderate stock price change (1-10\%) in ANZ's stock within the next year? Recall that your assessment prior to viewing this disclosure was [\#\# from baseline assessment]."
Highest likelihood of increase $+7$

4. What is the risk that ANZ's financial statements contain a material misstatement? No chance of a material misstatement

$$
0
$$

$\begin{array}{ll}1 & 2 \\ 0 & 0\end{array}$

3

4

5

6

7

8 $\circ$

Highly likely a material misstatement 10 ○

5. Please indicate the reasoning behind your revised assessments.

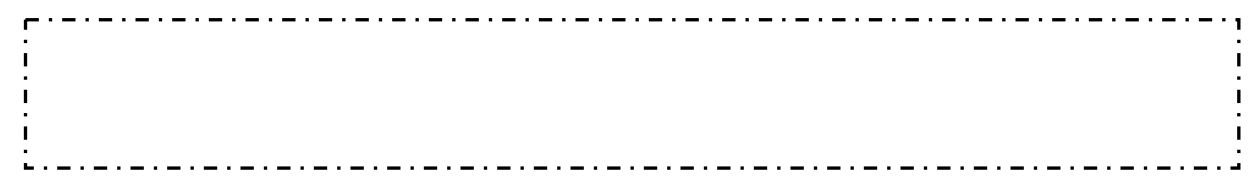




\section{MANIPULATION CHECK QUESTIONS}

(Please note that this title is not displayed to participants)

1. What was (were) the type of internal control issue(s) indicated in management's report on internal control over financial reporting?

- Three control deficiencies that are not material individually, but in aggregate, their combination could result in a material misstatement

- One material weakness that could result in a material misstatement

2. What was (were) the type of internal control issue(s) indicated in management's report on internal control over financial reporting?

Identified with bullet point(s)

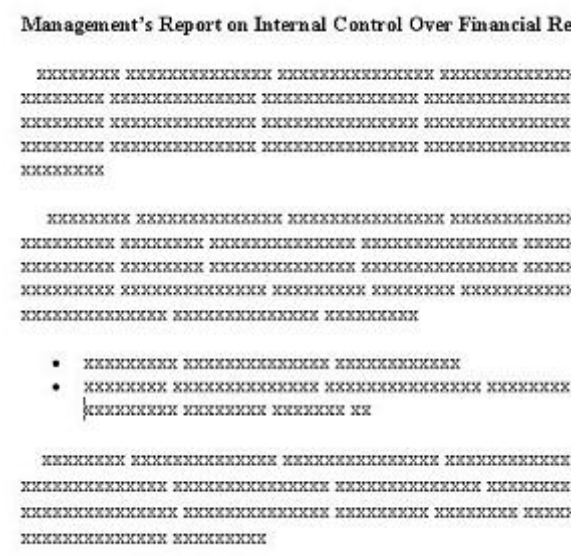

Not identified with bullet point(s)

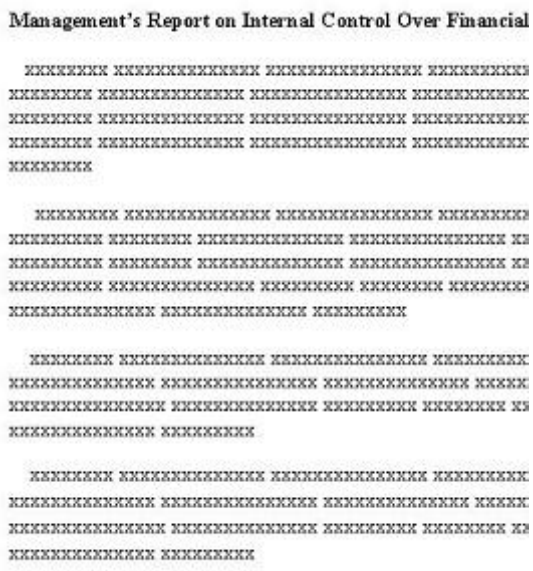

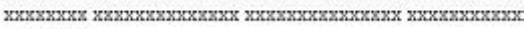
$x \times x \times x \times x \times$

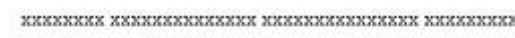

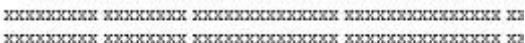

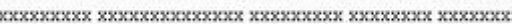

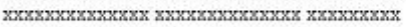

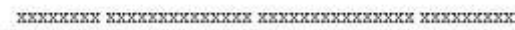

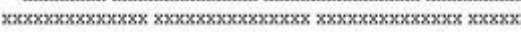

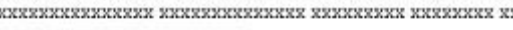

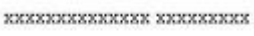

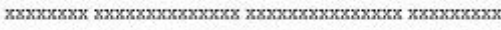

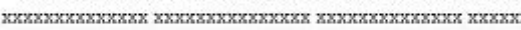

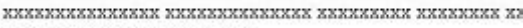

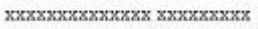

3. The specific section discussing the internal control issue(s) disclosed in management's internal control report was clearly presented and it was easy to understand whether a control issue or issues existed.

Strongly

Disagree

1

2
3

4
Strongly

Agree

7 
Recall that management identified the following control deficiencies that in aggregate constituted a material weakness [Replace the underlined text with "a material weakness" in aggregated conditions and the identified material weakness below - bolded writing not shown to participant] in internal control over financial reporting

- Ineffective controls to ensure the timely issuance of invoice adjustments

- Ineffective controls over the initiation of customer master records and contracts to ensure consistent billing of periodic charges

- Incompatible duties were not segregated within the billing function

1. Please rate your perceptions of the severity of the combination of issues in internal control (in aggregate). [Replace the underlined text with "the issue in internal control" in aggregated conditions bolded writing not shown to participant]

\begin{tabular}{|c|c|c|c|c|c|c|c|}
\hline & $\begin{array}{c}\text { Very low } \\
\text { severity } \\
1\end{array}$ & 2 & 3 & 4 & 5 & 6 & $\begin{array}{c}\text { Very high } \\
\text { severity }\end{array}$ \\
\hline $\begin{array}{c}\text { Combined severity of the } \\
\text { identified control deficiencies }\end{array}$ & 0 & 0 & 0 & 0 & 0 & 0 & 0 \\
\hline
\end{tabular}

2. What is the likelihood that the combination of the issues in internal control (in aggregate) will cause the financial statements to contain material errors? [Replace the underlined text with "the issue in internal control" in aggregated conditions - bolded writing not shown to participant]

\begin{tabular}{|c|c|c|c|c|c|c|c|c|c|c|c|}
\hline & $\begin{array}{c}0 \%- \\
\text { No } \\
\text { chance }\end{array}$ & $10 \%$ & $20 \%$ & $30 \%$ & $40 \%$ & $\begin{array}{c}50 \% \text { - } \\
\text { Coin flip } \\
\text { or } 50-50 \\
\text { chance } \\
\text { to cause } \\
\text { material } \\
\text { errors }\end{array}$ & $60 \%$ & $70 \%$ & $80 \%$ & $90 \%$ & $\begin{array}{c}100 \% \text { - } \\
\text { Certain } \\
\text { to cause } \\
\text { material } \\
\text { errors }\end{array}$ \\
\hline $\begin{array}{l}\text { Combined } \\
\text { effect of the } \\
\text { identified } \\
\text { control } \\
\text { deficiencies }\end{array}$ & 0 & 0 & 0 & 0 & 0 & 0 & 0 & 0 & 0 & 0 & 0 \\
\hline
\end{tabular}




\section{QUESTIONS ON THESE PAGE WERE ONLY ASKED IN DISAGGREGATED CONDITIONS}

(Please note that this title is not displayed to participants)

1. Please rate your perceptions of the severity of each of ANZ's identified issues in internal control.

\begin{tabular}{|c|c|c|c|c|c|c|c|}
\hline & $\begin{array}{c}1 \text { - Very low } \\
\text { severity }\end{array}$ & 2 & 3 & 4 & 5 & 6 & $\begin{array}{c}7 \text { - Very } \\
\text { high } \\
\text { severity }\end{array}$ \\
\hline $\begin{array}{c}\text { Ineffective controls to ensure the timely } \\
\text { issuance of invoice adjustments. } \\
\text { Ineffective controls over the initiation of } \\
\text { customer master records and contracts to } \\
\text { ensure consistent billing of periodic } \\
\text { charges }\end{array}$ & 0 & 0 & 0 & 0 & 0 & 0 & 0 \\
\hline $\begin{array}{c}\text { Incompatible duties were not } \\
\text { segregated within the billing function }\end{array}$ & 0 & 0 & 0 & 0 & 0 & 0 & 0 \\
\hline
\end{tabular}

2. Please rate your assessments of the likelihood that each of ANZ's issues in internal control will cause the financial statements to contain material errors.

\begin{tabular}{|c|c|c|c|c|c|c|c|c|c|c|c|}
\hline & $\begin{array}{l}0 \%- \\
\text { No } \\
\text { chance }\end{array}$ & $10 \%$ & $20 \%$ & $30 \%$ & $40 \%$ & $\begin{array}{c}50 \% \text { - Coin } \\
\text { flip or } 50 \text { - } \\
50 \text { chance } \\
\text { to cause a } \\
\text { material } \\
\text { error }\end{array}$ & $60 \%$ & $70 \%$ & $80 \%$ & $90 \%$ & $\begin{array}{c}100 \% \text { - } \\
\text { Certain to } \\
\text { cause a } \\
\text { material } \\
\text { error }\end{array}$ \\
\hline $\begin{array}{l}\text { Ineffective controls } \\
\text { to ensure the timely } \\
\text { issuance of invoice } \\
\text { adjustments }\end{array}$ & 0 & 0 & 0 & 0 & 0 & 0 & 0 & 0 & 0 & 0 & 0 \\
\hline $\begin{array}{l}\text { Ineffective controls } \\
\text { over the initiation of } \\
\text { customer master } \\
\text { records and contracts } \\
\text { to ensure consistent } \\
\text { billing of periodic } \\
\text { charges }\end{array}$ & 0 & 0 & 0 & 0 & 0 & 0 & 0 & 0 & 0 & 0 & 0 \\
\hline $\begin{array}{l}\text { Incompatible duties } \\
\text { were not } \\
\text { segregated within the } \\
\text { billing function }\end{array}$ & 0 & 0 & 0 & 0 & 0 & 0 & 0 & 0 & 0 & 0 & 0 \\
\hline
\end{tabular}




\section{QUESTIONS ON PERCEPTIONS OF MANAGEMENT}

(Please note that this title is not displayed to participants)

1. To what extent do you think you can rely on ANZ's internal control report?

\begin{tabular}{|c|c|c|c|c|c|c|}
\hline $\begin{array}{c}\text { Not at all } \\
1\end{array}$ & 2 & 3 & 4 & 5 & 6 & Completely \\
\hline 0 & 0 & 0 & 0 & 0 & 0 & 0 \\
\hline
\end{tabular}

2. I think that management is competent to prepare and communicate company disclosures to the public.

\begin{tabular}{|c|c|c|c|c|c|c|}
\hline $\begin{array}{c}\text { Strongly } \\
\text { disagree }\end{array}$ & & & & & & $\begin{array}{c}\text { Strongly } \\
\text { agree }\end{array}$ \\
\hline 1 & 2 & 3 & 4 & 5 & 6 & 7 \\
\hline 0 & 0 & 0 & 0 & 0 & 0 & 0 \\
\hline
\end{tabular}

3. I think that management is trustworthy in preparing and communicating company disclosures to the public.

\begin{tabular}{|c|c|c|c|c|c|c|}
\hline $\begin{array}{c}\text { Strongly } \\
\text { disagree }\end{array}$ & & & & & & $\begin{array}{c}\text { Strongly } \\
\text { agree }\end{array}$ \\
\hline 1 & 2 & 3 & 4 & 5 & 6 & 7 \\
\hline 0 & 0 & 0 & 0 & 0 & 0 & 0 \\
\hline
\end{tabular}

QUESTIONS FROM VAN ROOIJ ET AL. (2011) WERE USED TO MEASURE RISK PREFERENECES AND FINANCIAL LITERACY (NOT DISPLAYED HERE)

(Please note that this title is not displayed to participants) 


\section{POST-EXPERIMENTAL QUESTIONNAIRE}

(Please note that this title is not displayed to participants)

Please respond to these final set of questions - Your responses are highly valued, Thanks!

Did management indicate that the internal control over financial reporting was not effective?

\begin{tabular}{|c|c|c|}
\hline $\begin{array}{c}\text { Yes, the company's internal control } \\
\text { was not effective }\end{array}$ & $\begin{array}{c}\text { No, the company's internal } \\
\text { control was effective }\end{array}$ & I do not know \\
\hline O & 0 & 0 \\
\hline
\end{tabular}

How does the presence of internal control weaknesses affect a company's financial reporting system?

\begin{tabular}{|c|c|c|c|c|c|c|}
\hline $\begin{array}{c}\text { Negative } \\
\text { effect } \\
1\end{array}$ & 2 & 3 & 4 & 5 & 6 & $\begin{array}{c}\text { Positive } \\
\text { effect }\end{array}$ \\
\hline 0 & 0 & 0 & 0 & 0 & 0 & 0 \\
\hline
\end{tabular}

How would you rate your understanding of internal controls?

\begin{tabular}{|c|c|c|c|c|c|c|}
$\begin{array}{c}\text { Low level of } \\
\text { understanding }\end{array}$ & & & & & & $\begin{array}{c}\text { High level of } \\
\text { understanding }\end{array}$ \\
\hline 1 & 2 & 3 & 4 & 5 & 6 & 7 \\
\hline & 0 & 0 & 0 & 0 & 0 & 0 \\
\hline
\end{tabular}

All else equal, to what extent would your investing decisions be affected by the internal control disclosures on the effectiveness of internal controls over financial reporting?

\begin{tabular}{|c|c|c|c|c|c|c|}
$\begin{array}{c}\text { No, Internal control } \\
\text { disclosures do not affect } \\
\text { my investing decisions }\end{array}$ & & & & & & $\begin{array}{c}\text { Yes, Internal control } \\
\text { disclosures affect my } \\
\text { investing decisions }\end{array}$ \\
\hline 1 & 2 & 3 & 4 & 5 & 6 & 7 \\
\hline & 0 & 0 & 0 & 0 & 0 & 0 \\
\hline
\end{tabular}

All else equal, how severe do you consider control deficiencies to be relative to material weaknesses

\begin{tabular}{|c|c|c|c|c|c|c|}
$\begin{array}{c}\text { Control deficiencies are } \\
\text { much more severe than } \\
\text { Material weaknesses }\end{array}$ & & $\begin{array}{c}\text { Control deficiencies } \\
\text { and Material } \\
\text { weaknesses are of } \\
\text { equal severity }\end{array}$ & & & & $\begin{array}{c}\text { Material weaknesses are } \\
\text { much more severe than } \\
\text { Control deficiencies }\end{array}$ \\
\hline 1 & 2 & 3 & 4 & 5 & 6 & 7 \\
\hline 0 & 0 & 0 & 0 & 0 & 0 & 0 \\
\hline
\end{tabular}


How would you rate your familiarity with an annual report of a publically listed corporation (10-K)?

\begin{tabular}{|c|c|c|c|c|c|c|}
\hline $\begin{array}{c}\text { Not } \\
\text { familiar }\end{array}$ & & & & & & $\begin{array}{c}\text { Very } \\
\text { familiar }\end{array}$ \\
\hline 1 & 2 & 3 & 4 & 5 & 6 & 7 \\
\hline 0 & 0 & 0 & 0 & 0 & 0 & 0 \\
\hline
\end{tabular}

Would you please select “6” for this question?

\begin{tabular}{|c|c|c|c|c|c|c|}
\hline $\begin{array}{c}\text { Not } \\
\text { familiar } \\
1\end{array}$ & 2 & 3 & 4 & 5 & 6 & $\begin{array}{c}\text { Very } \\
\text { familiar }\end{array}$ \\
\hline 0 & 0 & 0 & 0 & 0 & 0 & 7 \\
\hline
\end{tabular}

Please indicate the frequency with which you read the following sections of a company's annual report

\begin{tabular}{|c|c|c|c|c|}
\hline & Never read & Sometimes read & Often read & Always read \\
\hline $\begin{array}{l}\text { Management } \\
\text { Discussion and } \\
\text { Analysis }\end{array}$ & $\mathrm{O}$ & $\mathrm{O}$ & $\mathrm{O}$ & $\mathrm{O}$ \\
\hline Auditor's Report & $\mathrm{O}$ & $\mathrm{O}$ & $\mathrm{O}$ & $\mathrm{O}$ \\
\hline $\begin{array}{l}\text { Notes to the } \\
\text { financial } \\
\text { statements }\end{array}$ & $\mathrm{O}$ & $\mathrm{O}$ & $\mathrm{O}$ & O \\
\hline
\end{tabular}

Did you make your investment decisions for a long-term investment or a short-term profit?

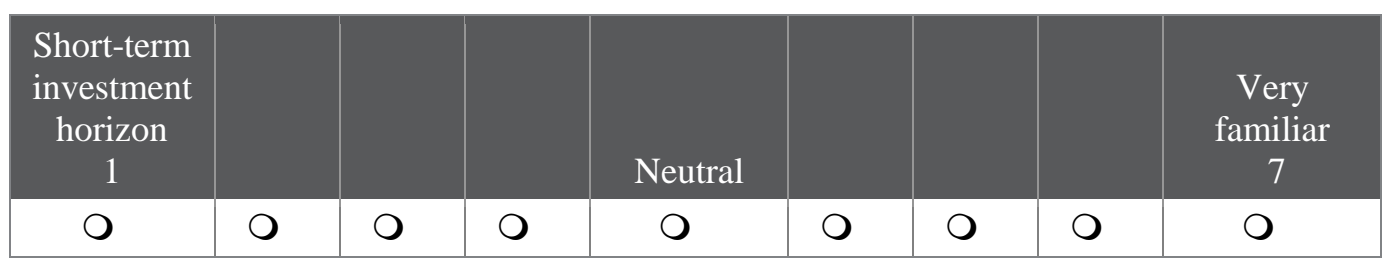

How many months has it been since you last actively sold or bought individual stocks in the stock market? (Put 0 if you haven't actively invested in stocks and 1 if you have sold or bought stocks in the past month) 
Approximately how many times do you trade (buy or sell individual stocks) in a year?

$$
\begin{array}{ll}
\text { O } & 0-10 \text { trades per year } \\
\text { O } & 10-100 \text { trades per year } \\
\text { O } & 100-1,000 \text { trades per year } \\
\text { O } & \text { Over } 1,000 \text { trades per year }
\end{array}
$$

To what extent do you use an intermediary financial adviser / investment broker / financial planner to manage your investments?

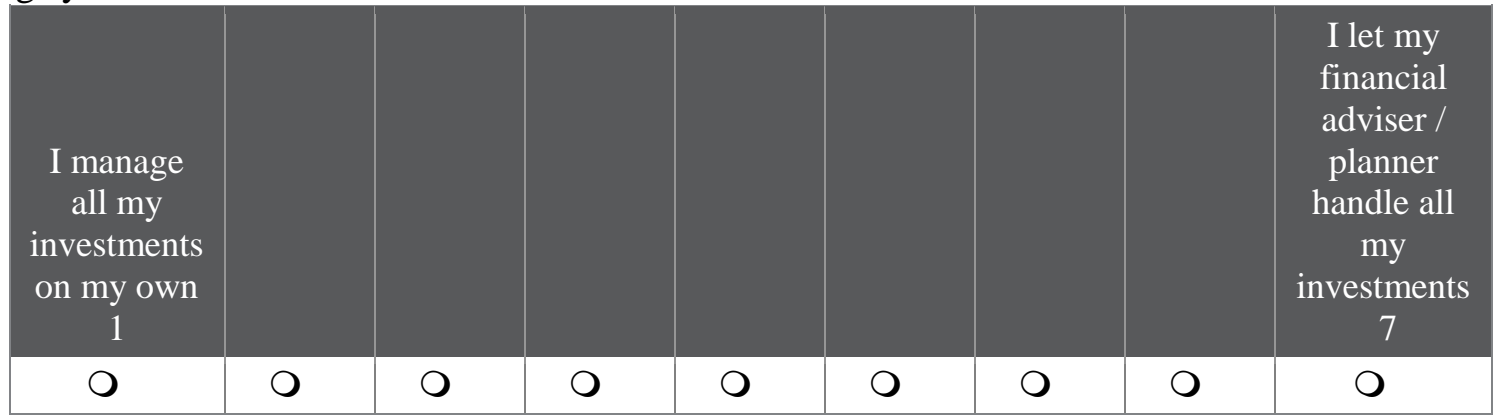

How many years has it been since you started buying or selling individual stocks on your own? (Put 0 if you have never actively invested in stocks and 1 if you have less than a year's worth of investing experience)

\section{DEMOGRAPHIC INFORMATION}

What is your age?

Please indicate your gender.
- Male
Female

What is the highest degree or level of schooling you have completed?

O No schooling completed

Some college credits, less than two years of full time coursework

O Associate degree, or over two years of full time coursework

O Bachelor's degree

O Master's degree

O Doctorate degree 
Do you have a business degree?
○ Yes
- No

How many accounting courses you have you taken? (Enter 0 for none)

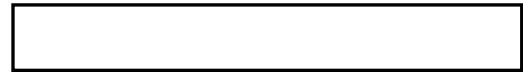

How many finance courses have you taken? (Enter 0 for none)

How many years of professional work experience do you have? (Put 0 if you have no professional work experience and 1 if you have less than a year's worth of professional work experience)

Thank you for participating in this survey. Please click next to save your responses. 


\section{Appendix B: IRB Approval Letter}

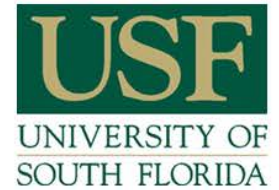

$7 / 2 / 2014$
RESEARCH INTEGRITY AND COMPLIANCE

Institutional Review Boards, FWA No. 00001669

12901 Bruce B. Downs Blvd., MDC035 • Tampa, FL 33612-4799

(813) $974-5638$ - FAX (813) $974-7091$

Amanuel Fekade, M.B.A.

USF School of Accountancy

4202 E. Fowler Ave. BSN 3514

Tampa, FL 33620

\section{RE: Exempt Certification}

IRB\#: Pro00018003

Title: Disclosures and Investing Decisions

\section{Study Approval Period: 7/2/2014 to 7/2/2019}

\section{Dear Mr. Fekade:}

On $7 / 2 / 2014$, the Institutional Review Board (IRB) determined that your research meets USF requirements and Federal Exemption criteria as outlined in the federal regulations at 45CFR46.101(b):

(2) Research involving the use of educational tests (cognitive, diagnostic, aptitude, achievement), survey procedures, interview procedures or observation of public behavior, unless:

(i) information obtained is recorded in such a manner that human subjects can be identified, directly or through identifiers linked to the subjects; and (ii) any disclosure of the human subjects' responses outside the research could reasonably place the subjects at risk of criminal or civil liability or be damaging to the subjects' financial standing, employability, or reputation.

Your study qualifies for a waiver of the requirements for the documentation of informed consent as outlined in the federal regulations at 45CFR46.117(c) which states that an IRB may waive the requirement for the investigator to obtain a signed consent form for some or all subjects if it finds either: (1) That the only record linking the subject and the research would be the consent document and the principal risk would be potential harm resulting from a breach of confidentiality. Each subject will be asked whether the subject wants documentation linking the subject with the research, and the subject's wishes will govern; or (2) That the research presents no more than minimal risk of harm to subjects and involves no procedures for which written consent is normally required outside of the research context.

As the principal investigator for this study, it is your responsibility to ensure that this research is conducted as outlined in your application and consistent with the ethical principles outlined in the Belmont Report and with USF IRB policies and procedures. Please note that changes to this 
protocol may disqualify it from exempt status. Please note that you are responsible for notifying the IRB prior to implementing any changes to the currently approved protocol.

The Institutional Review Board will maintain your exemption application for a period of five years from the date of approval or for three years after a Final Progress Report is received, whichever is longer. If you wish to continue this protocol beyond five years, you will need to submit a new application at least 60 days prior to the end of your exemption approval period. Should you complete this study prior to the end of the five-year period, you must submit a request to close the study.

We appreciate your dedication to the ethical conduct of hum an subject research at the University of South Florida and your continued commitment to human research protections. If you have any questions regarding this matter, please call 813-974-5638.

Sincerely,

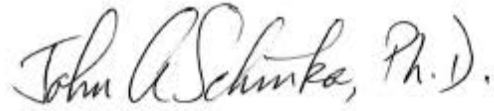

John Schinka, Ph.D., Chairperson

USF Institutional Review Board 